\title{
THE GREATER HALF OF THE CONTINENT: \\ CONTINENTALISM AND THE CANADIAN STATE IN \\ ONTARIO, 1878-1896 \\ by
}

Braden P.L. Hutchinson, B.A., B.Ed.

\author{
A thesis submitted to \\ the Faculty of Graduate Studies and Research \\ in partial fulfillment of \\ the requirements for the degree of
}

Master of Arts

Department of History

Carleton University

Ottawa, Ontario

June 6, 2008

(C) Copyright

2008 Braden P.L. Hutchinson 


$\begin{array}{ll}\begin{array}{l}\text { Library and } \\ \text { Archives Canada }\end{array} & \begin{array}{l}\text { Bibliothèque et } \\ \text { Archives Canada }\end{array} \\ \begin{array}{l}\text { Published Heritage } \\ \text { Branch }\end{array} & \begin{array}{l}\text { Direction du } \\ \text { Patrimoine de l'édition }\end{array} \\ \begin{array}{l}\text { 395 Wellington Street } \\ \text { Ottawa ON K1A 0N4 } \\ \text { Canada }\end{array} & \begin{array}{l}\text { O95, rue Wellington } \\ \text { Ottawa ON K1A 0N4 } \\ \text { Canada }\end{array}\end{array}$

Your file Votre référence

ISBN: 978-0-494-43466-6

Our file Notre référence

ISBN: 978-0-494-43466-6

NOTICE:

The author has granted a nonexclusive license allowing Library and Archives Canada to reproduce, publish, archive, preserve, conserve, communicate to the public by telecommunication or on the Internet, loan, distribute and sell theses worldwide, for commercial or noncommercial purposes, in microform, paper, electronic and/or any other formats.

The author retains copyright ownership and moral rights in this thesis. Neither the thesis nor substantial extracts from it may be printed or otherwise reproduced without the author's permission.
AVIS:

L'auteur a accordé une licence non exclusive permettant à la Bibliothèque et Archives Canada de reproduire, publier, archiver, sauvegarder, conserver, transmettre au public par télécommunication ou par l'Internet, prêter, distribuer et vendre des thèses partout dans le monde, à des fins commerciales ou autres, sur support microforme, papier, électronique et/ou autres formats.

L'auteur conserve la propriété du droit d'auteur et des droits moraux qui protège cette thèse. $\mathrm{Ni}$ la thèse ni des extraits substantiels de celle-ci ne doivent être imprimés ou autrement reproduits sans son autorisation.
In compliance with the Canadian

Privacy Act some supporting forms may have been removed from this thesis.

While these forms may be included in the document page count, their removal does not represent any loss of content from the thesis.
Conformément à la loi canadienne sur la protection de la vie privée, quelques formulaires secondaires ont été enlevés de cette thèse.

Bien que ces formulaires aient inclus dans la pagination, il n'y aura aucun contenu manquant.

\section{Canada}




\begin{abstract}
$\underline{\text { Abstract }}$
Using Foucault's concepts of governmentality and counter-conduct, this thesis examines the significance of the continentalist movement to Ontario politics and governance between 1878-1896. By situating the movement in the broader developments of Canadian state formation, chiefly the National Policy, as well as the continental aspects of daily life in Ontario, the thesis attempts to amplify the scholarship of the continentalist movement by providing an explanation of the geneaology of the movement and its subsequent formalization as a counter-conduct aimed at reorganizing governance in the Canadian state along civic republican lines. Similarly, the thesis traces the popular manifestations of continentalism, particularly among agrarian classes, and the various reactions to these popular manifestations by the Liberal and Conservative parties between 1887-1896, leading to the eventual marginalization of the movement and the emergence by 1896 of a short-lived orthodoxy of protectionism.
\end{abstract}




\section{$\underline{\text { Acknowledgments }}$}

In carrying these imagined worlds above our heads it is always upon someone else's shoulders that we brace ourselves. With this in mind, I must first and foremost thank my friends and family and my loving fiancée for their support and encouragement no matter how absurd and strange this seems from the outside. Without their patience and tolerance for my fanciful pursuits, it is most certain they never would have come this far.

To my thesis advisor, Duncan McDowall, I owe a tremendous debt of gratitude for his sharp editorial eye and staunch commitment to the sometimes neglected truth that historians, above all else, are story tellers. Without his expert assistance, this thesis would not have been as readable, nor as intelligently argued as it presently is.

I also would like to thank John C. Walsh, Matthew Bellamy and Bruce Elliott for their guidance on particular aspects of this thesis and their very helpful feedback on early versions of some of the chapters.

I am also indebted to the Department of History at Carleton University, as well as the generous donors to the department and the University for the excellent financial support they provided me with. Without their faith in the project, it would not have been completed in as timely a fashion.

In a similar vein, the Graduate Secretary Joan White has been indispensable in providing myself, as well as other students, with up to date information and support. Without her help fulfilling the requirements of any Graduate program would be significantly more challenging.

I would like to thank my henceforth nameless travel companion, Patrick Watson, not only for accompanying me on my pilgrimage to "the other side of the line", but for 
providing me with feedback on early drafts of the first chapter. Also, I owe a tremendous debt of gratitude to my roommate Andrew Bene for reading a full draft of this thesis and providing excellent editorial feedback.

Finally, I would like to thank my grandfather, D.H. Lander for his staunch support of the FTA and NAFTA in the 1980s and 1990s and my parents for their equally vocal opposition. Certainly, growing up in the midst of dinner table debates about Canada's economic future are in large part responsible for my choice of topic. And so it is to them that I dedicate this thesis.

All errors and shortcomings are my own. 


\section{TABLE OF CONTENTS}

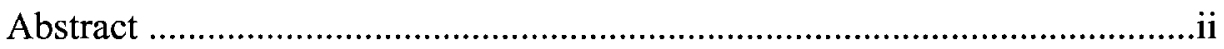

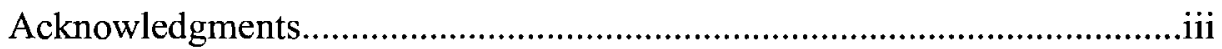

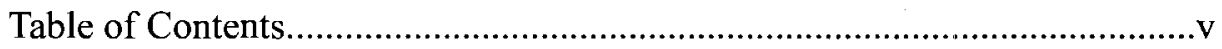

Introduction: August 26, 2007 - Fort Erie Ontario.......................................................

Chapter 1: Continentalism in the Political Landscape of Late-Nineteenth Century

Ontario.

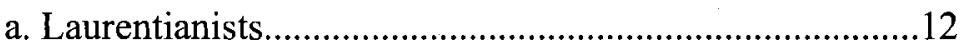

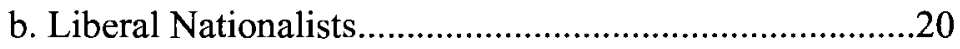

c. Theoretical Considerations I...........................................29

d. Theoretical Considerations II..........................................41

Chapter 2: Informal Counter-Conduct: The National Policy, Smuggling \&

Emigration.

a. The Minister and His Ministry.......................................57

b. From Taxation to Protection..........................................62

c. The Counter-Conduct of Smuggling................................75

d. The Counter-Conduct of Emigration................................81

e. Coding the Behaviour....................................................93

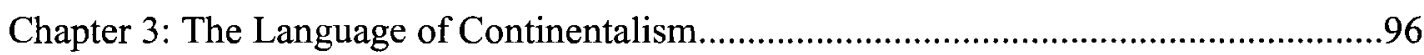

a. Bio-power and the Market..............................................104

b. Faction, Corruption and Degeneration.........................112

c. The Nation and the State............................................122

d. Getting the Word Out...................................................133

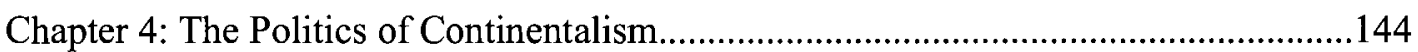

a. The Farmers' Institutes..............................................148

b. Inside the Meeting......................................................154

c. The Liberal Party and Unrestricted Reciprocity............167

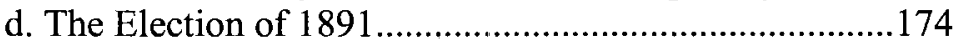

Chapter 5: The End of the Continental Vision..............................................................190

a. The Death of a Prime Minister......................................194

b. Annexationism as Counter-Conduct..............................204

c. The Liberal Party Responds.......................................210

d. The Attack on Continentalism.......................................213

e. Consolidating the New Politics of Loyalty.....................221

f. The Tariff Commission of $1896 \ldots \ldots \ldots \ldots \ldots \ldots \ldots \ldots \ldots \ldots \ldots . . . .231$ 


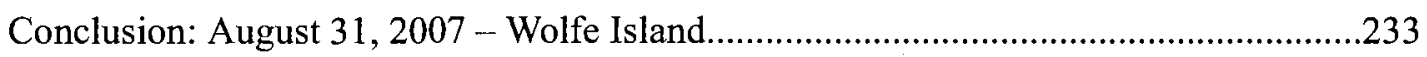

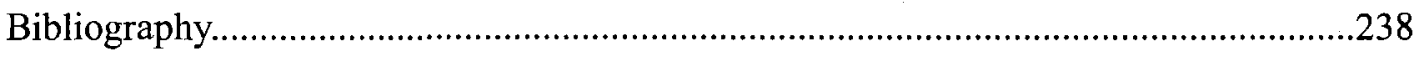




\section{Introduction: August 26, 2007-Fort Erie, Ontario}

I stop the car, somewhat abruptly, at the bright red light. It stares me right in the face. I'm worried now. Maybe I stopped too abruptly. Maybe now they are going to search my car and throw my luggage, along with the luggage of my travelling companion all over the ground. I can feel my shirt getting damp under the arms. Sweat is starting to bead on my forehead. Just as I'm starting to rehearse what I'm going to say in my head, the light turns green and I pull forward, again a little too anxiously.

The red light has been replaced with the opaque gaze of a U.S. Border Service agent, staring at me through his darkened aviators. I wish I could see his eyes. His face doesn't smile when I offer him an enthusiastic "Good day". My friendliness seems to make him more suspicious. He just sticks out his hand for the passports. I pass mine and my friend's through the window.

After tapping his keyboard and staring at his screen for a few minutes, the border guard looks back over at me and begins the interrogation. I can feel more sweat coming out of my pores as I wilt under his opaque gaze.

"Where are you two from?"

“Ottawa," we answer in absurd unison.

"What is your business in the United States?"

“Vacation," I say. "Were going to visit a friend who's starting his $\mathrm{PhD}$ at Cornell."

"How long will you be in the U.S.?" His monotone is almost unnerving.

"Four days." 
"What do you two do for a living?"

"I'm a teacher," I answer, guessing that this sounds less suspicious than graduate student.

"I work for the government," my companion replies.

Without a word, the border guard turns like it's an automatic reflex and hands us back our passports. "Enjoy your trip," he says in a humourless and unaffected voice. With that, we pass across the border and into a foreign country.

Beyond the frontier there is something deeply familiar about everything. The landscape has not changed much. The trees still look the same. The pavement is still the same grey. I am still driving on a multi-lane highway. My travelling companion picked up a brochure on the Finger Lakes region of New York where Cornell is located. I notice that upstate New York, not unlike the Niagara Peninsula from which we just emerged, is famous for its wine. My eyes can plainly see that there is nothing at all that is really much different, except that the speed limit signs force me to refer to the smaller numbers on my speedometer.

But something feels different about this place. Part of it is that my road atlas tells me this place is different. The pages in this section are tabbed orange, not blue as are the Canadian pages. And the main reference map calls this place the United States of 
America. But the cars, the scenery, so much of it is all the same. Something between that red light and the highway on-ramp had affected me.

After no more than 15 minutes on the highway I am feeling this affectation even more deeply. I know I am somewhere unfamiliar, regardless of what my eyes tell me. I take the next exit I see and pull into a familiar fast-food restaurant. My companion and I get out and decide that 11:30am isn't too early for lunch.

As I'm standing in line waiting to order I am looking for differences in this place so strangely familiar - right down to the colour scheme and the way people sound when they speak. I almost immediately hit on the fact that the medium sized soft drinks are about twice the size of mediums in Canada. This fact seems to put me a little more at ease; evidence that my eyes were in fact playing tricks on me back there.

My eyes were playing tricks on me earlier, when I looked across the upper St. Lawrence between Brockville and Kingston at what was supposedly another country. Even my cell phone got confused as it switched to an American network on the Thousand Islands Parkway. The radio too played its part in the conspiracy, offering up stations from across the narrow river. Hadn't the cellular companies and the radio stations ever read Innis or Creighton? Didn't they know that the current of the St. Lawrence runs east-west? Or did Creighton forget that rivers are easier to traverse then to navigate? 
After we jump back on the Interstate, as they call their highways here, I can't help but think about the research I had been doing all summer on the National Policy, continentalism and the loyalty election of 1891 . It seemed to me that everywhere I looked in those dusty old documents someone in John A. Macdonald's Liberal-Conservative party was busy telling people who imagined a camaraderie between Canada and the United States that they were wrong, or worse, traitors to their country. Continentalism, as historians have chosen to name this diverse and loosely organized movement, which held as an objective closer political and economic ties with the United States, was unwelcome in Canadian history. My initial response when I started my thesis on continentalism was to ignore these allegations of treason; allegations that the Liberal Party and individuals such as Goldwin Smith, Edward Farrer and Erastus Wiman - the "architects" of the movement for a continentalist policy for Canada - were somehow un-Canadian. But these kinds of claims were not only in the archival material, they were in historians' books. Entire generations of historians had made less than flattering characterizations about some or all of those involved in the continentalist movement. The luckiest of the band were the likes of Laurier, who historians felt was redeemed by his eventual decision to recant on the policy of a customs union with the United States after his defeat in the election of 1891 at the hands of Macdonald's "Old Flag, Old Policy, Old Leader" campaign. And while I surely felt that Macdonald and his cabal truly did fear the effect of a continental policy of either commercial or political union, I wondered how it was that he convinced so many other Canadians, including the leadership of the Liberal Party, to be afraid as well? 
Though this was to be my break from my research, it was clear that a trip to Cornell University would be anything but a respite. Cornell University: where Goldwin Smith, the arch-continentalist, was a professor and who upon his death bequeathed his fortune to the school. Cornell University: where Goldwin Smith Hall stood as home to the humanities and a testament to Smith's commitment to free and universal education for all who were capable. While it was to be my vacation, I secretly hoped that maybe Cornell would offer some answers to this disoriented traveller.

My research had had a profound impact on me. It was an almost ironic topic for me to research. As a child I could remember my parents and grandparents debating the virtues and vices of the Free Trade Agreement, and then only a few years later, NAFTA. Not only was it my parent's economic nationalism and grandfather's ardent continentalism that stuck with me, but also the dismal news reports as the economy reeled under the profound structural changes of free trade. I had thought then, and for a long time after, that my parents were right. The FTA and NAFTA had been a mistake. I held onto this belief almost unshaken until stumbling upon Goldwin Smith's Canada and the Canadian Question while in my Canadian historiography seminar. "The Bystander," as Smith styled himself, had cast a spell on me. And rather than try to fight it, it felt as if I needed to dive in, head first.

This trip, it seemed, would in many ways act as a rehearsal for what I was going to write when I got back. It was a kind of practice session where I could work out the kinks in my mind before committing incomplete thoughts to the merciless semi-permanency of paper. It was time to reflect. 
I reached over to the radio and turned up the volume. My friend and I had been travelling in silence for nearly fifteen minutes now. As I followed the gentle curves of the Interstate, I began to think about what I would say about people and places that I had encountered first as echoes, and still, only as documents. How would I write about them? How would I make them into my history? Where would I begin? 


\title{
Chapter 1: \\ Continentalism in the Political Landscape of Late- Nineteenth Century Ontario
}

\author{
Public support of annexationism in Canada then, like \\ support of the Communist Party in the United States now, \\ was tantamount to treason. ${ }^{l}$ \\ -- D.F. Warner, 1960
}

Entering Ottawa's Beechwood cemetery is like entering a museum of Canadian national history. Just past the main gate, off to the left, is Poets' Hill, where the likes of Archibald Lampman rest peacefully. His grave and those of others are marked by commemorative plaques asking us as visitors to remember their contributions to the development of a national literature. As you crest Poets' Hill, you are confronted to your immediate right by the gazebo constructed in honour of the RCMP officers who have given their life in the line of duty. Just beyond the gazebo the mausoleum, towering over the cemetery. In the shadow of this great building you can find the graves of many nineteenth century nation builders - Robert Borden, Prime Minister, is there, as is Henry James Morgan, a writer and member of the Canada First movement of the 1870s. All have plaques that situate them in the national panoply. All, we are told, played a significant role in building Canada. As you move deeper into the cemetery and towards the national military cemetery, flags flapping in the distance, you cannot but notice the multitude of little markers telling you that other great Canadians are buried here, too. In winter, a little dusting of the snow with one's sleeve is sometimes necessary to uncover

\footnotetext{
${ }^{1}$ D.F. Warner, The Idea of Continental Union: Agitation for the Annexation of Canada to the United States, 1849-1893, (University of Kentucky Press, 1960), vi.
} 
the short paragraphs detailing the contributions of individuals to Canadian national development. In the summer you can imagine such little pieces of history grabbing the eye and drawing the visitor towards the haphazard exhibition of the national story. ${ }^{2}$

Finally, if you venture deep enough into the 160 acre grounds, you will find yourself in a small valley between the military cemetery and the fortress-like mausoleum. Just to the right of the main path at plot 39 is a small monument. Here, under the cover of the now barren poplar and oak trees, is the small grave of Edward Farrer. If you were not looking for his grave, as I was, you would not have found it. In fact, the headstone was only added in 1978 by a relative, 62 years after his initial burial. It required more then a mere brushing off of snow to unearth this chapter of Canadian history. A history lesson set out by the incongruities of death.

From the only biography of Farrer, The Secret Craft: The Journalism of Edward Farrer by Carman Cumming, published in 1992 and shelved in the journalism sections of libraries, it becomes clear that Farrer was seen by many of his contemporaries not just as a journalist par excellence, but also as something of scoundrel ${ }^{3}$ Not the stuff of national greatness worthy of commemoration. Indeed, he often spread misinformation about his personal history. Many considered him to be both disloyal and a mercenary. However, Farrer was also the editor of The Daily Mail ${ }^{4}$, a significant Toronto newspaper in the nineteenth century and one of Canada's first independent, rather than party, papers. Farrer was also considered by many to be the greatest journalist of the post-Confederation age,

\footnotetext{
${ }^{2}$ See www.beechwoodcemetery.com

${ }^{3}$ Carman Cumming, Secret Craft: The Journalism of Edward Farrer, (Toronto: Universty of Toronto Press, 1992), xi-xii.

${ }^{4}$ The Mail would later merge with the Globe and become the Globe and Mail
} 
one whose style and pen were notorious for their sharp wit and even sharper criticism. ${ }^{5}$ Long time friend and political associate, Walter Dymond Gregory, backhandedly remarked that Farrer was "...one of the greatest men, intellectually, that I ever knew...if he had only had character he would have gone a long way." In an age when journalists were truly the great public intellectuals they still claim to be, Farrer was most definitely a major figure in the shaping of Canadian opinion during a pivotal age in Canada's national history.

A Grit most of his life, Farrer became a kind of Liberal party "fixer" following the Liberal election victory of 1896 , often attempting to solicit information of Tory wrongdoing that he would then pass on to the Party. Farrer, it would seem, was a man worthy of a Beechwod cemetery plaque, yet plot 39 remains ungraced by the wand of heritage. Perhaps, though, it is also important to note that Farrer is the most notorious annexationist in Canadian history.

Farrer has, in fact, basked in a distinctly anti-national limelight. Farrer strongly believed that Canada was doomed from the beginning. First and foremost, he believed that racial, linguistic and class factionalism gnawed at its unity. Secondly, he disparaged the tawdry corruption of the patronage politics of John A. Macdonald. Finally, the pull of the United States and the ambivalence of Great Britain towards Canada's future militated, he believed, against true national unity. All these pressures indicated to Farrer that Canada should naturally and willingly dissolve into the United States.

\footnotetext{
${ }^{5}$ Carman Cumming, "The Toronto Daily Mail, Edward Farrer, and the Question of Canadian-American Union," in Journal of Canadian Studies Vol. 24(1) 1980, 123. Cumming also notes on page 122 the peculiar choice by historians to treat commercial union with loaded term like "a-whoring" and "touted" ${ }^{6}$ Walter Dymond Gregory, The Autobiography of Walter Dymond Gregory [unpublished], The Walter Dymond Gregory Papers, Box 9, Queen's University Archives, 98-99.
} 
Today, despite the sympathetic treatment provided by Cummings' biography, Farrer is still often the target of distaste by historians. Farrer made it onto Beaver magazine's 2007 list of historians' picks for “Worst Canadians". Farrer's inclusion on the list was because, in the words of Margaret Conrad, "Had Farrer's arguments carried the day, there would be no Canada at all." ${ }^{\prime 7}$ Back at Beechwood a different story is on display. There, it is Sir Robert Borden who receives the national kudos of having saved Canada from the clutches of America in the fateful election of 1911.

Farrer is not the only figure of continentalism to have been treated in a confused and unsympathetic manner. In the first few decades following Confederation, a diverse and vibrant body of continentalist thought emerged which ranged from the annexationism of Farrer to the political union of Goldwin Smith to the more politically correct commercial union and Unrestricted Reciprocity of Erastus Wiman and the Liberal Party, respectively. Just as with Farrer's life, the history of these political options has been obscured by historians, either through deliberate omission in some instances, or by pointed accusations of treason by others.

The objective of this dissertation is to rethink the meaning and significance of the continentalist movement and to resituate it in our national historiography. Any attempt at understanding this legacy must move beyond the narrow and factious discussion which has hitherto characterized historical writing on post-confederation politics, where continentalism has all too often served as a convenient and largely unexamined whipping boy for those interested in bolstering the cause of national unity. Instead, it is essential to situate continentalism within the context of political culture in the late nineteenth century:

\footnotetext{
${ }^{7}$ Margaret Conrad, "Edward Farrer" The Beaver 2007(August/September), 37.
} 
a political culture which was much more receptive to the agrarian-centred American republican ideas than has been previously thought. In order to do this properly, the map of the Ontario political tradition for the period is in desperate need of redrawing. Facile characterizations of toryism against liberalism have become untenable in the history of pre-confederation Ontario thanks to the work of historians and political scientists such as Jeffrey McNairn, Janet Azjenstat and Peter Smith. Yet aside from the often confused and contradictory "liberal order framework", there has been little recent examination of Ontario political culture between the years 1867 and $1896 .^{8}$

Before reconceptualizing political culture in the post-confederation era, it is essential first to examine the problems and assumptions of the existing historiography, which have made an effective and meaningful evaluation of continentalism nearly impossible. There exist two major historiographical schools in the debate about Ontario political culture and continentalism in the late nineteenth century: the Laurentianists, the Liberal Nationalists. While neither of the existing schools offers up a wholly promising new direction for understanding the significance of continentalism to the world of postconfederation politics, other newly trodden paths of inquiry offer some promising opportunities. Using some of the ideas of the emergent neo-ideologist school, none of which have dealt with continentalism directly, as well as the work of Michel Foucault, this thesis will attempt to "reimagine" the significance of continentalism in late nineteenth century post-confederation politics.

\footnotetext{
${ }^{8}$ In S.J.R. Noel Patrons, Clients, Brokers: Ontario Society and Politics, 1791-1896, (Toronto: University of Toronto Press, 1990), Noel attempts to outline the political culture of patronage in Ontario. While an important work on patronage, it does not deal with how the changing structures of patronage networks reflect articulations of particular political traditions.
} 


\section{Laurentianists}

The [negative] opinion [this study] synthesizes [concerning the United States] is that of the politically effective minority... it is doubtful that the views of the inarticulate majority of Canadians were much different from those of their political spokesmen. ${ }^{9}-$ S.F. Wise, 1967

Canada Views the United States by S.F. Wise and Robert Craig Brown traces the evolution of mostly central Canadian opinions of the United States. Though the book is supposed to be about how Canadians in British North America viewed the United States, as the above quotation indicates, their analysis actually deals with how the political elites, largely those in Upper Canada, viewed the United States. The elitism of their work coupled with the suspicion with which they treat the United States is symptomatic of the Laurentian school, that primordial school of Canadian historical thinking.

The Laurentian interpretation of continentalism is the oldest and most hostile of the three broad schools. Beginning with the historical work of Donald Creighton in the 1930s, the Laurentian interpretation stresses the foreignness and anti-nationalism of the continentalist agitation. The definition of Canadian nationalism used by the Laurentianists is that of "defensive expansionism." This theory of Canadian nationalism, as arch-Laurentian Hugh G.J. Aitken wrote, holds that

The [Canadian] Government has been compelled to accept responsibility for creating and conserving a national economy. This has presented its political leaders with the task of defining and continually redefining a strategy of national economic survival sufficiently feasible and attractive to offset the ever-present alternative of absorption

\footnotetext{
${ }^{9}$ S.F. Wise \& R.C. Brown, Canada Views the United States, (Seattle: University of Washington Press,
} 1967), 16 . 
by the larger and more powerful [American] economy to the south. ${ }^{10}$

In a metanarrative such as the one above, the United States and those who seek

closer relations with it are engaged in a denial of Canada's existence. Donald Creighton, the originator of this view, was less explicit then Aitken, but no less dismissive of

continentalism as a viable alternative to the National Policy system:

People were now [in the late 1880s] in the mood for desperate remedies - just as they had been in the years from 1873-1878...In the Maritime Provinces and in certain parts of Ontario, a significant number of people, unconnected with politics, were already beginning to advocate the abandonment of protection and the substitution of a radically different policy, commercial union with the United States. Obviously no more frontal attack upon Canadian economic nationalism could have been devised. ${ }^{11}$

Creighton's emphasis on the desperation of the annexationist alternative to the national policy and the language of invasion creates a sense of "otherness" around continentalism. In launching "frontal attacks," continentalism takes on the guise, not of an indigenous political movement responding to legitimate political concerns, but of a foreign invader. It is in Creighton's words the product of individuals "unconnected with politics" and by extension the Canadian national project.

In Canada's First Century, 1867-1967, Creighton further unfolds his nationalist umbrella to encompass imperialists, especially G.M. Grant, who wrote "the most effective rejoinder to [Goldwin] Smith's book, Canada and the Canadian Question."12 In Creighton's revised narrative, the imperialists become the intellectual defenders of the

\footnotetext{
${ }^{10}$ Hugh G.J. Aitken, "Government and Business in Canada: an interpretation" in Douglass McCalla (ed.) The Development of Canadian Capitalism, (Toronto: Copp Clark Publishing, 1990), 111.

${ }^{11}$ D.G. Creighton, John A. Macdonald: the Old Chieftaine, Vol. 2 (Toronto: Mcmillan, 1955), 468-469.

${ }^{12}$ D.G. Creighton, Canada's First Century, 1867-1967. (Toronto: McMillan, 1970), 77.
} 
Canadian nation. Thus, the nationalist heroes were to be played by the Conservatives and the imperialists, while those who sided with continentalism played the role of villain. Throughout his career, Creighton displayed a penchant for historical polarities Macdonald the Centralist vs. Mowat the Provincialist - and his treatment of continentalism fits easily into this writing formula.

Aitken and Creighton's other disciples were to continue to dominate the discussion of continentalism throughout the 1960s and 1970s. Carl Berger's work, The Sense of Power, was an eloquent elaboration of Creighton's claim that the imperialists were the intellectual defenders of the Canadian national project. They "sensed" the true dimensions of Canadian nationhood. Berger writes:

Nor can it be doubted that the depression in Canada and the threat of unrestricted reciprocity enhanced the appeal of imperial federation in general and activated the campaign for imperial preferential trade as an antidote to continental free trade. ${ }^{13}$

Berger's use of medical terms such as "antidote," and his conviction that continentalism was the product of economic crisis show the continuation of characterization of continentalism as a foreign contagion: a poison afflicting the body politic to be purged.

Another disciple of Creighton, R.C. Brown, comes at continentalism from the economic angle to similar conclusions in Canada's National Policy, 1883-1900: A study in Canadian-American Relations. Though Brown does concede that "the idea of

${ }^{13}$ Carl Berger, The Sense of Power: Studies in the Ideas of Canadian Imperialism, 1867-1914, (Toronto: University of Toronto Press, 1970), 7. See also Carl Berger, Imperialism and Nationalism, 1884-1914: A Conflict in Canadian Thought. (Toronto: Copp Clark Publishing, 1969). 
commercial union with the United States was not new," it is still characterized as a threat to the new nation. ${ }^{14}$ Brown's language is telling:

[the election of 1891] did appear to be a vindication of the National Policy of a separate Canadian entity on the North American continent, and a rebuke of continentalism. But the margin of victory was narrow and the "old leader," recognizing it, prepared to kill continentalism as it had not been killed by the Canadian electorate. ${ }^{15}$

Along with the need to "kill" continentalism, Brown equates Macdonald's National Policy - which includes almost everything the state does, by Brown's definition - with the existence and maintenance of Canada as a separate entity. ${ }^{16}$ Interestingly, these historians learned to avert their eyes when economic historians such as J.H. Dales suggested that the numbers did not support their unbridled admiration for the lynchpin of John A. Macdonald's brand of nationalism. ${ }^{17}$

Brown's fondness for large expansive categories also gave him the license to include under continentalism the many movements - unrestricted reciprocity, commercial union, and annexationism - that for other Laurentianists remained disconnected outbursts at times of crisis. Therefore, Brown at least provides his reader with the notion that continentalism does have a continuing history with a legitimacy of its own in Canada, even if that history is something to be feared and even loathed.

American scholars of Canada's late-nineteenth century debates have also tended to side with the Laurentianists. Though free from the immediate pull of Canadian

\footnotetext{
${ }^{14}$ R.C. Brown, Canada's National Policy, 1883-1900: A study in Canadian-American Relations, (Princeton, NJ: Princeton University Press, 1964), 127.

${ }^{15}$ Ibid., 211.

${ }^{16}$ Brown's definition of the national policy will be discussed at length in chapter two.

${ }^{17}$ See J.H. Dales, "National Policy Myths, Past and Present", Journal of Canadian Studies, Vol. 14 No. 3, $1979,92-94$.
} 
nationalism, American scholars of Canada have derived much of their background information on Canadian history from the work of Canadian national historians. American scholars are not necessarily free from the idea of Canada and the United States as two significantly different experiments in liberal democracy.. Admittedly, much American interest in Canada is motivated by the idea of its putative role as a North American alternative. As such, the metanarrative of the Canadian Laurentian school pervades the writing of American scholars as well. The finest example of work on American-Canadian relations in the late-nineteenth century done by an American is Gordon T. Stewart's The American Response to Canada since 1776. According to Stewart, the policy objective of the United States was to prevent the rise of a rival empire on the northern half of the continent. By denying Canada reciprocity with the U.S, the American government, it is argued, hoped that Canada would be weakened economically. This objective complemented the Conservative policy of defensive expansionism following $1879 .{ }^{18} \mathrm{Of}$ course, this was Macdonald's version of the Canadian national project in a period in which many alternatives, including continentalism, vied for dominance. While Macdonald developed and articulated his national policy vision, the alienation of the United States as a result of Canadian trade actions and the rise of imperial federation led Americans to abandon reciprocity completely. ${ }^{19}$ Stewart tells the story of the victorious sides in the debate. In the end, both Canada and the United States opted for protectionism by the early 1890 s, an outcome best characterized by the stringent McKinley tariff of 1891. Stewart does not mention those Americans who saw the extension of market access

\footnotetext{
${ }^{18}$ Gordon T. Stewart, The American Response to Canada since 1776. (East Lansing, MI: University of Michigan Press, 1992), 83-84

${ }^{19}$ Stewart, 93
} 
to Canada as part of an American protectionist policy, nor does he reference those Canadians who continued to hold strong continentalist beliefs after the national policies election. Again, the penchant to portray this debate in procrustean terms appears when neither country in fact harboured homogenous thinking on the issue.

A book by Alvin C. Gluek titled Minnesota and the Manifest Destiny of the NorthWest focuses on the defensive nationalism of Canada and how it foiled the plans of Minnesotans who wished to annex the Canadian north-west in the later half of the $19^{\text {th }}$ century. While Glueck identifies the bustling 'free trade' between the Red River settlement and Minnesota during the early years of Confederation ${ }^{20}$, this takes a back seat to what Glueck sees as the opinion of Canadians, represented through the actions of the Canadian state, that the north-west was part of the manifest destiny of Canada. ${ }^{21}$ While this was true of some Canadians, some who favoured the acquisition of the north-west also favoured free trade with the United States. The continentalist viewpoint is again conspicuously absent. Both Glueck and Stewart give wonderfully detailed accounts of history from the centre, but neither explains how divergent opinions shaped and influenced the approach of Canadians to the United States.

One of only three monographs devoted entirely to continentalism in Canada is a product of American scholarship. However, it is evident that D.F. Warner's The Idea of Continental Union: Agitation for the Annexation of Canada to the United States, 18491893 was also an interpretation heavily influenced by the Laurentian tradition. Warner makes the strange and misleading decision to assume that movements like Unrestricted

\footnotetext{
${ }^{20}$ Alvin C. Glueck, Minnesota and the Manifest Destiny of the North-West: A study in Canadian-American Relations, (Toronto: University of Toronto Press, 1965), vii.

${ }^{21}$ Glueck, 228.
} 
Reciprocity and commercial union were in fact movements in favour of annexation by another name. This decision is not surprising as Warner roots his view in Canadian and American political records, which in the Canadian context, were the product of Macdonald's Liberal-Conservative allies. This leads Warner to the overly-simplistic conclusion that all continentalist perspectives agreed with the radical annexationist project of Farrer and the like. Annexation becomes synonymous with continentalism when Warner declares that "The mainspring of the annexation agitation was always economic distress, coupled with the melancholy conviction that Canada lacked, and would never have, the ingredients of a viable national economy." 22 Warner also ignores divisions between bona fide annexationists that divided them into two camps: political unionists and annexationists. The former favoured the continuation of British style institutions at the provincial level within the context of the American republic, while the later favoured a complete abandonment of constitutional monarchy in favour of a republican style system and full absorption into the United States. ${ }^{23}$ Even more troubling, as the above quotation indicates, Warner focuses almost exclusively on materialist causes to account for the rise of continentalism, rather than examining political traditions and changes in the practices of governance by the Canadian state.

The Laurentianists continue to cast their shadow, obscuring the significance and meaning of continentalism for Canadian political culture. In a Queen's M.A. thesis by Patricia K. Wood, the influence of Creighton is still easily detected. Wood writes that:

Macdonald's congratulatory telegrams and letters reflected how deeply the sympathetic electorate had absorbed the

\footnotetext{
${ }^{22}$ Warner, 247.

${ }^{23}$ See Goldwin Smith, Canada and the Canadian Question, (London: McMillan, 1891), 212.
} 
Conservatives' images of Canada and the Liberals during the campaign [of 1891]. ${ }^{24}$

Wood echoes Creighton and the other Laurentianists in declaring continentalism to be somehow unpopular or undesireable to the "people" of Canada. As outlined above, the Laurentian scholarship on continentalism suffers from the assumption that Macdonald's national project - specifically as it is embodied in an expansively defined national policy - is in fact the only legitimate state project. One senses that any acknowledgment of alternative national political cultures on the part of these Macdonaldian nationalists is rooted in their determination to bolster national unity at times of crisis.

Continentalism thus becomes a foreign agent to be eradicated from the body of Canadian political culture. This stigmatization of continentalism as "the other" in Canadian political culture has meant that Laurentianists have been incapable of viewing continentalism in any fashion other than through the lense of the national policy - a lense, according to some historians, which is the product of primal insecurities about the fate of Canada and a hagiographic love for Macdonald. ${ }^{25}$ The achievement of a balanced treatment of continentalism by the Laurentianists is further hampered by their elitist approach to history in general, which places more emphasis on the ideas of elites rather than climbing further down the socio-economic ladder. This myopia is compounded by their blatant disregard for regional differences within Canada. Yet the question remains whether Liberal nationalist historians have faired any better in unravelling the politics of continentalism.

\footnotetext{
${ }^{24}$ Patricia Wood, "Under Which Flag, Canadian?" Anti-Americanism and the Election of 1891. Kingston, ON: Queen's University: M.A. Thesis, 1991, 101.

${ }^{25}$ See J.H. Dales, "National Policy' Myths, Past and Present" Journal of Canadian Studies 14(3), 1979, 9294.
} 


\section{Liberal Nationalists}

I suspect that his [Goldwin Smith's] real influence is yet to come and will be exercised upon those Canadian historians... who fall under the spell of the bystander and come to see how shrewd were his comments on current events, how enlightening his criticisms of the nature of Canadian nationality and how far reaching his conception of the place of Canada in the English-speaking world ${ }^{26}$.F.H. Underhill, 1960

As the above epigraph would seem to indicate, Liberal Nationalists have tended to view continentalism in a somewhat more sympathetic light, largely because it does not enter into their narratives as prominently. While the Laurentians embrace a metanarrative of defensive expansionism, the Liberal Nationalist school opts for another metanarrative: that of progress from colony to fully independent nation. They hold diplomatic and constitutional independence to be the ultimate expression of Canadian nationalism, much as do the Laurentians. As such, they are often equally elitist in their assumptions and interests. Yet, this constitutional and diplomatic evolution as conceived by the Liberal Nationalist school views Canada as part of a positive tripartite relationship between Great Britain and the United States in which trade with both in goods and ideas has been central to the survival and development of Canada. As such, they are more suspicious of Macdonaldian enterprises, but also tend to understate the significance of continentalism.

\footnotetext{
${ }^{26}$ F.H. Underhill, In Search of Canadian Liberalism, (Toronto: McMillan, 1960), 85-86. Underhill's generally sympathetic approach to continentalism is also visible in The Image of Confederation. (Toronto: Hunter Rose, 1964), 34. where he declares "I know of no method of scientific analysis by which it can be proved or disproved that free trade between the two peoples [of Canada and the United States], in 1891 or in 1963, would be destructive of our national identity. Perhaps... it is necessary for Canadians to believe in an American hell in order to preserve the vital force of the Canadian national religion. To be a liberal rather than a fundamentalist in one's political religion requires a very high type of mind and character...it is always other Canadians and not ourselves who are liable to be demoralized and de-Canadianized by truck or trade with the Yankees."
} 
Continentalism in the metanarrative of colony to nation holds little significance except as a factor in the eventual diplomatic reproachment between Canada and the United States that came in the twentieth century after Canada had extricated itself from the apron strings of mother Britain. The result in all liberal nationalists, save two, is an unwillingness to enter into an in-depth treatment of continentalism.

Counted amongst the production of Liberal Nationalist historians are largely sympathetic biographies of Goldwin Smith, such as that by Elisabeth Wallace, which concludes that Goldwin Smith's views on Canadian politics resulted from his disillusionment following the failure of the cultural nationalism of the Canada First movement and his unfamiliarity with Canadian circumstances and Canadian character. ${ }^{27}$ In a similar vein, Carman Cumming, in her biography of Edward Farrer mentioned earlier, is sympathetic towards Farrer, but generally avoids weighing in on the controversy over continentalism, focusing instead on Farrer's journalistic talent. ${ }^{28}$ The decision by both historians to give continentalism short shrift through either ambivalence or avoidance is indicative of the Liberal Nationalist approach outlined above.

Some Liberal Nationalist historians in their search for a liberal equivalent to the Macdonaldian vision would be less sympathetic. In the biography he penned on Sir Richard Cartwright, W.R. Graham, a historian strongly supportive of Canadian

\footnotetext{
${ }^{27}$ Elisabeth Wallace, Goldwin Smith: Victorian Liberal (Toronto: University of Toronto Press, 1957), 263. A more recent biography of Smith from 2002 titled The Controversialist by Paul T. Phillips offers little new as far as Smith's continentalist views. The only new conceptualization of Smith which is of interest is that of Smith as an early Liberal Internationalist and while this is true to some measure it draws attention away from his explicitly continentalist views in regards to Canada and its place in the English speaking world. A biography of Smith in the form of an unpublished Phd thesis by David McEachern is not discussed here as it is largely descriptive and avoids Smith's continentalism save to say that it was a controversial belief that was not widely accepted.

${ }^{28}$ Carman Cumming, Secret Craft, 4-11.
} 
independence from both Great Britain and the United States, stops short of accusing Cartwright of treason. Still, Graham implies that once the Liberals had adopted the policy of Unrestricted Reciprocity they had moved towards treasonous ground, only to be rescued from the abyss by the work of "true" liberal nationalists like Oliver Mowat and Edward Blake. ${ }^{29}$ Thus, for Graham, the march from colony to nation was almost interrupted by continentalism, which sought a different mode of dependency for Canada. As is clear, this metanarrative does little better in rehabilitating the continentalist legacy.

Others, such as historian P.B. Waite, were more apologetic and defensive in their tone. In Macdonald: His Life and World, Waite identifies the hypocrisy of the Conservatives' repudiation of unrestricted reciprocity, since they too wanted to acquire some kind of reciprocity agreement with the United States, and had been sniffing around Washington seeking reciprocity just before the 1891 election. ${ }^{30}$ In his work of three years previous, Canada 1874-1896: Arduous Destiny, Waite, while providing a less partisan perspective, still made sure to remark that the Conservative decision to invoke the "loyalty cry" showed that "[p]atriotism is the last refuge of a weak cause." 31 Yet, when it came to discussing continentalism's impact on the election of 1891, Waite was happy to dismiss it as the result of the Western Ontario "rural vote". ${ }^{32}$ While not incorrect that farmers played a significant role in the movement, it is a perspective that explains little about how continentalism functioned or how important such a rural vote would actually have been in a province whose main industry was still agriculture. This is reflective of

\footnotetext{
${ }^{29}$ W.R. Graham, Richard Cartwright and the Liberal party, 1863-1896. (Toronto: University of Toronto Press, 1950), 256. In W.R. Graham, "Liberal Nationalism in the 1870s", in Canadian Historical Association, 1946. Graham makes the case for a true liberal nationalism embodied in Edward Blake. ${ }^{30}$ P.B. Waite, Macdonald: His Life and World, (Toronto: McGraw-Hill-Ryerson, 1974), 204-205.

${ }^{31}$ P.B. Waite, Canada 1874-1896: Arduous Destiny, (Toronto: McClelland and Stewart, 1971), 225

${ }^{32}$ Ibid.
} 
the declaration in one of the book's earlier chapters that "...the federal idea was still difficult for Canadians to make into a meaningful measure of their nationality," implying not that there was any pull towards the rest of the continent, but rather that regionalism and the colonial remnant were to blame for disunity and the failure of a coherent nationalism to emerge. ${ }^{33}$ Continentalism features only cursorily in Waite's narrative about Canada's "arduous destiny"; a title which implies that movements such as continentalism should deserve far more attention.

Historian Ian Grant's work provides a foil to that of W.R. Graham. Grant argues that certain branches of continentalism, particularly that put forward by Wiman, were in fact strongly nationalistic. ${ }^{34}$ Grant’s article "Erastus Wiman: A Continentalist Replies to Canadian Imperialism" was written by an undergraduate as a reply to Berger's claims in The Sense of Power discussed above. Yet, Grant's decision to accept the implied terms of debate used by the Laurentians of nationalism versus continentalism, of independent nation versus dependent colony, limits his ability to extend a meaningful analysis to continentalism as a whole, confining his article to dealing exclusively with the ideas of Erastus Wiman, who acts as a kind of apologist for the movement as a whole. As such, little about the political significance of the movement is revealed by Grant's analysis, save how the ideas of one of its chief leaders compare to a fixed definition of nationalism.

Frank Underhill takes another approach, choosing to exclude continentalism, characterizing it as a movement irrelevant to the mainstream of Canadian politics.

Underhill concludes that Goldwin Smith's influence was minimal among his

\footnotetext{
${ }^{33}$ Ibid., 200.

${ }^{34}$ See lan Grant. "Erastus Wiman: A Continentalist Replies to Canadian Imperialism." Canadian Historical Review 1972 53(1): 1-20.
} 
contemporaries in Canada. For Underhill, it was only the radical farmers of south-western Ontario who were displeased with the national policy, due to the increased cost of goods under the National Policy tariff. ${ }^{35}$ The implication is that continentalism was a fringe belief, an implication, which, as has already been stated, is on shaky ground. Though there was admiration on the part of Underhill for Goldwin Smith, his essay paints a picture of a character estranged from the people of Canada. ${ }^{36}$

Underhill's conviction that continentalism was an agrarian movement, best understood in socio-economic terms, also influenced one of the only other major piece written directly on continentalism. The University of Western Ontario M.A. thesis by I.A. Hodson "Commercial Union, Unrestricted Reciprocity and the Background to the Elections of 1891 " concludes in 1952 , before many of the above works were penned, that continentalism, though advocated by intellectuals since the inception of the National Policy, became popular among farmers spontaneously in $1887 .{ }^{37}$ Yet, Hodson in the end concludes that there was no unifying class basis for the overall movement. ${ }^{38}$ His deviation from Underhill is the result of a close and careful reading of newspapers that advocated for a continentalist solution. What Hodson suggests is that the calls for reciprocity with the United States were often mixed with calls for reciprocity with Great Britain. Thus, there is evidence of an overlap between continentalism and imperialism or

\footnotetext{
${ }^{35}$ F.H. Underhill, In Search of Canadian Liberalism, (Toronto: McMillan, 1960), 41. This essay's main focus is on Smith as a contributor to the development of Liberalism in Canada. It is similar to the treatment given to him by Malcolm Ross in his essay which is not discussed in this paper due to its similarity in focus to the text cited above.

${ }^{36}$ Ibid, 102-103

${ }^{37}$ Hodson, I.A. Commercial Union, Unrestricted Reciprocity and the Background to the Election of 1891. London, ON: University of Western Ontario: M.A. Thesis, 1952, 87.

${ }^{38}$ Ibid., 134.
} 
Anglo-Saxonism, a fitting conclusion from the Liberal Nationalist perspective. ${ }^{39}$ Any discussion of continentalism must deal with the distinction between those who thought that free trade constituted a sound economic policy and those who thought that North America constituted a 'natural' political and/or economic unit. Furthermore, various schemes for a continental solution - commercial union, Unrestricted Reciprocity, and political union/annexation - lead Hodson to conclude that advocates were unclear on the meaning of continentalism. ${ }^{40}$ The absence of a clear class base as well as the myriad of possible continental solutions suggest a more variegated causation behind continentalism, located potentially in the local Ontario political tradition which favoured a particular kind of moral economy and political community, substantively different than the one advocated by the Liberal-Conservative Party. Continentalism, if such an assertion proves to be true, may only be a rallying point for a deeper concern about the very shape of the Canadian state project as it had been developing since the mid-1870s, rather than a small tangent on the march from colony to nation.

Hodson is alone among all the historians discussed in conceiving of continentalism as a movement that was regionally centred in Ontario during the $1880 \mathrm{~s}$. It is this recognition that allows Hodson to probe continentalism more effectively then the other historians outlined above. While the Laurentians dumbed continentalism down into a unified heresy, the Liberal Nationalist contribution, taken as a whole, suggests a more nuanced and complex movement with roots that go deeper than simple material self-

\footnotetext{
${ }^{39}$ In Edward P. Kohn, This Kindred People: Canadian-American Relations \& the Anglos-Saxon Idea, 18951903, (Montreal: McGill-Queen's University Press, 2004) traces the role on Anglo-Saxonism in the AngloAmerican reproachement of the early twentieth century. No other work exists focusing on the prevalence of this idea in the late-nineteenth century in Canada or its relationship to continentalism. This is one relationship this thesis will explore in brief in chapter three.

${ }^{40}$ Hodson, 98.
} 
interest. However, their commitment to a metanarrative of colony to nation has led them either to dismiss or to ignore continentalism in most cases, and in all cases to take a top down approach to the movement. The focus on the agrarian class by Underhill and Hodson as a category of analysis heavily influenced the small contribution of Marxist historians. The neo-marxist school tended to approach the question of continentalism from the perspective of the class politics of Macdonald's National Policy tariff.

Continentalism does not figure prominently in their narratives as often the focus of neomarxism has been on the dialectic of the industrial labour force against the bourgeoisie, the Canadian state and the business interests. Agrarian interests receive limited attention. One minor exception to this trend is "The Class Politics of the National Policy, 18721933" by historians Paul Craven and Tom Traves. The article comes to a less nuanced, simpler and somewhat faulty conclusion than that of Hodson: that continentalism was a product of a particular class experience, that of farming. ${ }^{41}$ And while farmers did form the bulk of the support for continentalism, it is important to note that certain businessmen and intellectuals such as Cartwright, Farrer and Smith also supported the movement. These individuals are simply left out of the discussion due to a slavish devotion to recount all historical events in terms of simplistic class antagonism mediated through the state.

Though the Liberal tradition shows evidence of a less manipulative approach to continentalism, based on the diversity of opinion ranging from apologetic to hostile, it is still clear that Liberal historians are no more effective in fitting continentalism into their conception of Ontario political culture than the Laurentians. Whether a dangerous "other"

\footnotetext{
${ }^{41}$ Paul Craven and Tom Traves, "The Class Politics of the National Policy, 1872-1933" Journal of Canadian Studies 14(3), 1979, 15.
} 
or popular enigma, Canadian history has provided few answers about the nature of continentalism in late nineteenth century Canada.

The above conclusion, while true of much that was written in previous decades, has in recent years been turned on its head by a young historian. Christopher Pennington, in his dissertation The Continentalist Movement in the Politics of Canada and the United States, $1887-1894$, undertakes the daunting task of rescuing the movement from near oblivion. It must be added that this is only possible, ironically, due to his commitment to the metanarrative of colony to nation while writing in an era where continental free trade has become a twenty-first century symbol of Canadian confidence and national independence, an era very different from the one that produced the above-mentioned works. Pennington crafts a masterful narrative of the movement's formal development and decline between 1887 and 1894. Furthermore, his story is one that in and of itself defies borders as he traces the movement's growth and development in both Canada and the United States. Pennington's ultimate claim is that it was against "long odds" that the continentalist movement gained as much support as it did "north of the border" ${ }^{42}$ Furthermore, Pennington situates his story in the Liberal Nationalist metanarrative when he asserts that continentalism has outlasted its opposite, and as such, recovering this tradition is essential to shedding light on the present condition of the Canadian political and economic orientation, implying its significance in the transition from a colony of Great Britain to a nation on the North American continent. ${ }^{43}$ This thesis does not aim to take issue with any of these conclusions or to undermine Pennington's efforts to integrate

\footnotetext{
${ }^{42}$ Pennignton, Christopher. The Continentalist Movement in the Politics of Canada and the United States, 1887-1894. Toronto: University of Toronto: PhD Dissertation, 2007, 33-34.

${ }^{43}$ Ibid.
} 
continentalism into the Canadian metanarrative of colony to nation. Rather, its aim is to act as a revision of some of Pennington's methodological approaches and his assumptions about the movement.

A great deal of Pennington's analysis is devoted to the activities of the movement's elites and the Liberal Party. While his attention to the actions of these groups has been indispensable to this thesis, he does not devote sufficient attention to how the discourse of continentalism was received on the ground, nor to how those who supported it came to conduct themselves in the furthering of the movement's objectives. Further to the issue of discourse, Pennington does not spend sufficient time analysing the discursive content of the continentalist movement in order to understand its relationship to questions of governance and resistance during the post-confederation period of state formation. Certainly continentalism provided a meaningful critique of Macdonald's protective system, but precisely how these critiques developed and in what concrete behaviours they were rooted is a question that is still left unanswered. Finally, the use of spectacle by the various groups involved is also something that Penington spends little time on. Thus, while Pennington flirts with post-modernist analysis, he fails to apply its tools.

These few omissions are perfectly understandable given the gargantuan task Pennington has undertaken in providing a narrative of the continentalist movement in both countries. This thesis prefers, instead, the much more confined breadth of Hodson in the hopes of allowing for greater depth. As such, it will confine itself to the continentalist movement and its relevance to the people of Ontario in the hopes of recapturing the voices of those not part of the intellectual of political elite of the province and comparing 
those voices with the discursive creation of the movement's elite. Yet, while this thesis has made the commitment to depth over breadth and aims, much as Pennington does, to reconsider the movement with greater empathy, the question as to the actual theoretical approach to be used to allow for a deconstruction of the movement is still unresolved. Some might suggest that to discuss theory here is merely smoke and mirrors. However, establishing a sound theoretical basis for this thesis has the effect of making the metanarrative transparent and open to critique. Theory is to be used throughout, not to obfuscate, but to avoid the black-boxing of assumptions in the hope that further criticisms of this topic will open new and exciting avenues for explication. With this in mind, the attention of this chapter will now turn towards the question of theoretical approaches to continentalism, evaluating those that have been suggested by historians and political scientists alike and thereby ultimately explaining the reasons behind a decision to utilize a Foucauldian approach in dealing with continentalism.

Theoretical Considerations I: The Neo-ideologists \& Political Culture

...that the Government of this Province may be made most agreeable to the Monarchy under which we live, and of which this Province is a part; and that we may avoid erecting a numerous democracy...44 ${ }^{4-}$ John Locke

The old tension of toryism vs. liberalism is strongly reflected in the foregoing two sections on the Laurentian and Liberal Nationalist historians. While this perceived ideological tension is still the mainstay of popular interpretations of Canadian history,

\footnotetext{
${ }^{44}$ John Locke, The Fundamental Constitution of Carolina, n.d. 2.
} 
recent scholarship has uncovered other political traditions in Ontario which competed in equal measure with toryism and liberalism for the control of the Canadian state.

The above passage from John Locke's Fundamental Constitution of Carolina serves to highlight an important tension between the political cultures of liberalism and republicanism. Locke makes it clear in this constitution that the objective of liberalism is not democratic rule by the people, but rather the creation of a meritocratic order grounded in the primacy of property derived through labour. It is this tension between liberalism and rule by the people that has led in recent years to the development and expansion of a diverse group of historians interested in explaining political culture in terms of the impact of liberalism and republicanism, rather than in terms of the tension between toryism and liberalism. While they vary in their political coloration from committed liberals, republicans to Gramscian Marxists, they constitute a school, in that all prefer to analyse ideologies and political cultures with a focus on the state and language. For the sake of categorization, this thesis labels them the Neo-Ideologists. While their attempts to rehabilitate Canadian history of the late-nineteenth century through the uncovering of a new traditions - namely civic republicanism - and their attempt to account for the power of ideologies are admirable, their lack of engagement with post-structuralist theory has made their analyses overly-simplistic in their reliance on hard fixed categories and divisions between groups of political actors. Yet what has been important, at least amongst the republican or civic humanist wing of this group, has been their uncovering of a vibrant republican tradition in Canada. As Iseult Honohan defines it,

Civic republicanism addresses the problem of freedom among human beings who are necessarily interdependent. 
As a response it proposes that freedom, political and personal, may be realized through membership of a political community in which those who are mutually vulnerable and share a common fate may jointly be able to exercise some collective direction over their lives...In this approach, freedom is related to participation in self-government and concern for the common good... Republican politics is concerned with enabling interdependent citizens to deliberate on, and realise, the common goods of an historically evolving political community, at least as much as promoting individual interests and protecting individual rights...[it represents] a reaction to...the excessive liberal stress on individual independence... [with calls] for the restoration of community, citizenship and moral purpose in politics. $^{45}$

Liberty, fraternity, equality: no simpler statement of the republican creed has ever been devised in the modern history of the west. What these three words point to is an emphasis of independence as a pre-requisite to political participation, rather than the byproduct of such participation. They indicate by extension that this freedom, as well as the socio-political status of the individual, must be substantively similar or equal. Excesses lead us to the final point of fraternity, which does not merely imply interdependence, but rather an active associational life measured in terms of virtue and vice between independent equal citizens. It is this line of thought which led Bruce James Smith to declare that "the Republic is a set of habits, customs, traditions and institutions which buttress public life." ${ }^{46}$ So while, on the one hand, republicanism has the potential to be highly democratic and egalitarian, it can at the same time emphasize submission to tradition and the primacy of political virtue through tradition as a precondition for liberty.

\footnotetext{
${ }^{45}$ Iseult Honohan, Civic Republicanism, (New York: Routledge, 2002), 1.

${ }^{46}$ Bruce James Smith, Politics \& Rememberance: Republican Themes in Machiavelli, Burke and Tocqueville, (Princeton, NJ: Princeton University Press, 1985), 6.
} 
Republicanism governs by placing community prior to, and necessary for, democracy and political rights.

To illustrate this point further, one can refer to the quotation from Honohan above or to a more popular source: the preamble of the Constitution of the United States of America (1787):

WE THE PEOPLE of the United States, in Order to form a more perfect Union, establish justice, ensure domestic tranquility, provide for the common defence, promote the general Welfare, and secure the Blessings of Liberty to ourselves and Posterity, do ordain and establish this CONSTITUTION for the United States of America. ${ }^{47}$

Though it begins with a democratic declaration of "we the people" and ends with the aim of securing liberty, the objectives in between point to a more coercive political project in order that the people may come to experience liberty; a project which emphasizes order, tranquility, interdependence and general welfare as the preconditions of freedom.

Earlier Canadian historians of the nineteenth century, like the Laurentianists, Liberal Nationalists and neo-Marxists, have assumed that the many factions which would eventually come to form the Liberal Party gained their populist sentiments and commitment to democracy from liberalism of a Millian type. What has become increasingly clear in light of recent scholarship by the republican wing of the neoideologist group - a group which aims at exploring the depths of civic republican values and political projects in Canada - is that these sentiments in favour of agrarian democracy

\footnotetext{
${ }^{47}$ The Constitution of the United States of America in James Madison, Alexander Hamilton and John Jay, The Federalist Papers, (London: Penguin, 1987), 491.
} 
and claims for "Rep by Pop" ${ }^{48}$ by Grit reformers have their origin in a civic republican tradition. This was tradition which took root in Canada with the arrival of the United Empire Loyalists, and more significantly, the late loyalists of the early nineteenth century who had been imbued with Jeffersonian ideas about the ideal interdependent political community of yeoman farmers. ${ }^{49}$

In the opening essay to their edited collection of essays on Canadian political culture Canada's Origin: Liberal, Tory, or Republican, Peter J. Smith and Janet Azjenstat make the case for the presence of republican and liberal ideologies from the outset:

The formative influence in Canada's past was not solely liberalism, or the combination of liberalism and tory conservatism, but a lively opposition between liberalism and a civic republican philosophy with a progressive agenda. ${ }^{50}$

In the edited collection and Peter Smith's book on civic republicanism in Canada, the case is made that after arriving with the loyalists, civic republicanism often challenged Lockean orthodox liberalism and the toryism of the family compact in the early period of Upper Canadian history culminating in the rebellions of 1837 and 1838 . The failure of the rebellions and the creation of responsible government through the implementation of the Durham report secured the dominance of liberalism over slowly but surely declining civic republican tradition.

\footnotetext{
${ }^{48}$ In David E. Smith, The Republican Option in Canada: Past and Present, (Toronto: University of Toronto Press, 1999), 95. Smith argues that representation is at the very root of the republican tradition and so claims about representation must be understood as emanating from a republican perspective.

${ }^{49}$ For a discussion of this see Peter J. Smith, "Civic Humanism Versus Liberalism: Fitting the Loyalists In," in Janet Azjenstat \& Peter J. Smith (ed.) Canada's Origin: Liberal, Tory, or Republican? (Ottawa: Carleton University Press, 1995), 109-135

${ }^{50}$ Janet Azjenstat \& Peter J. Smith, "Liberal-Republicanism: The Revisionist Picture of Canada's Founding" in Janet Azjenstat \& Peter J. Smith (ed.) Canada's Origin: Liberal, Tory, or Republican?, (Ottawa: Carleton University Press, 1995), 1.
} 
While an interesting interpretation, it falls into the structuralist trap that mistakes correlation for causation. Nowhere is it explained how the Durham Report secured liberalism's dominance. Rather, almost magically through a realignment of the political institutions of Upper Canada and using liberal turns of phrase, the colony was cleansed of its republicanism when its name changed to Canada West.

Azjenstat and Smith also make the peculiar decision to locate this civic republican ideology on the "political left". ${ }^{1}$ Aside from the obvious ahistorical use of terms like "left" and "right" in the context of the nineteenth century outside of France proper, this choice polarizes any discussion of politics in a blind attempt to see the nineteenth century political landscape in terms of binaries. This kind of categorization seems anachronistic.

In The Capacity to Judge, Jeffrey McNairn spends two chapters exploding this left-right anachronism by outlining the presence of republican discourse both within the newspapers and within the rank and file of the Conservative Party. ${ }^{52}$ The so called "Tory Republicanism" identified by McNairn casts serious doubt on the view held by Smith and Azjenstat that republicanism is the exclusive creature of the left. Even in returning to the intellectual fathers of conservatism as, Bruce James Smith does in Politics and Remembrance, it becomes clear that republican themes of community and civic virtue were prevalent in the writings of Edmund Burke, the supposed intellectual father of Canadian conservatism. ${ }^{53}$

To toss aside the debates about republicanism's leftist or rightist credentials for the moment, what is clear is that republican themes and tropes could provide a grounding for

\footnotetext{
${ }^{51}$ Ibid.

${ }^{52}$ See Jeffrey McNairn, The Capacity to Judge: Public Opinion and Deliberative Democracy in Upper Canada, 1791-1854. (Toronto: University of Toronto Press, 2000), 237-303.

${ }^{53}$ See Bruce James Smith, Politics and Rememberance, 102-154
} 
authoritative claims about the political good or political right, usually by those engaged in a project of dissent from the established order. Yet no attempt has been made by historians to trace the trajectory of civic republicanism into the post-confederation period nor to move beyond a structuralist obsession with language and discourse at the expense of examining actual action and behaviour among elites and non-elites.

Similar structuralist flaws also plague the Liberal and Gramscian wings of the neo-ideologist school. Azjenstat, in her most recent work, The Canadian Founding: John Locke and Parliament, tackles the question of Confederation and argues that Confederation and the 1867 British North America Act were the product of Lockean liberalism which stressed material improvement and the protection of property under the umbrella of the name Liberal-Conservative. ${ }^{54}$ While it is clear that the vast majority of Liberal-Conservatives abandoned their commitment to the "tory republicanism" outlined by McNairn, it is unclear in Azjenstat's work whether or not much of the Ontario population was as quick to adopt a purified liberalism. In short, by failing to engage with performance, action, or behaviour by the masses, Azjenstat's work tells us little other than what the vision of the Fathers of Confederation was.

The final member of this neo-ideological camp that will be examined is the Gramscian Ian McKay. In his article "The Liberal Order Framework: a prospectus for the reconnaissance of Canadian history" and his recent book Rebels, Reds, Radicals:

Rethinking Canada's Left History, McKay puts forward the view of one hegemonic liberal project of rule which has dominated or incorporated all other competing political cultures.

\footnotetext{
${ }^{54}$ For a discussion of the Orthodox nature of Macdonald's liberalism see Janet Azjenstat, The Canadian Founding: John Locke and Parliament, (Montreal: McGill-Queen's University Press, 2007).
} 
While MacKay suggests that it is necessary to explain how the Canadian liberal project differs from other similar projects, he dismisses debates about the shape of this liberal project, such as those over the National Policy and commercial union to be "important... not fundamental." ${ }^{55}$ McKay goes further to say that as historians of the liberal order it is necessary to recognize that:

What connects the farmer's fence with Macdonald's tariff is a common respect for private property and the propertied individual as the foundation of a sociopolitical order ultimately defended by the state's legitimate violence. What it meant to succeed, to own things, to shine as a success in the eyes of one's parents, to be a real man, to construct lines on maps and barriers around whole countries, to separate what's 'mine' from 'yours', 'ours' from 'theirs': with regard to these fundamental questions of property, the farmer's fence post and the prime minister's tariff policy share a common universe of assumptions and values. ${ }^{56}$

The above excerpt seems to indicate McKay's injunction for historians to read certain behaviours as liberal rituals. While McKay must be commended for suggesting that non-linguistic objects, like fences and maps for example, embody certain discursive meanings and function as rituals that reinforce political projects, he assumes that all behaviour is somehow the by-product of liberalism as a set of values. McKay's equation of the National Policy with the farmer's fence does not correspond to the historical evidence, which suggests that while Macdonald portrayed and rationalized the National Policy in these terms, this line of thought was not satisfactory to those farmers who actively opposed it and saw their own fences very differently than the one Macdonald tried to construct. Hodson's work already tells us that farmers formed the bulk of

${ }^{5 s}$ Ian McKay, Rebels, Reds, Radicals: rethinking Canada's left history, (Toronto: Between the Lines, 2005), 58.

${ }^{56}$ Ian McKay, "The liberal order framework: A prospectus for a reconnaissance of Canadian history" The Canadian Historical Review. Dec 2000. Vol. 81(4), 638. 
resistance in Ontario to the implementation of the National Policy. Equality for independent individuals before the law was not only a feature of liberalism, but also of republican creeds. McKay ignores the tensions ${ }^{57}$ within his bloated definition of liberalism between community and individual and between society and state. While McKay's talk of values and assumptions is interesting, it also does not get to the root of the issue. Rather, it provides a simplistic picture that inadvertently hides the depth and breadth of the penetration of liberalism and other possible political cultures by stopping at simply reading various behaviours as rituals. It does not ask how these rituals are viewed by others, how they are resisted and how they disciplined participants. It does not concern itself with making explicit the relations of power at work under these conditions. Rather, it relies on the haggard Marxist assumption that power is vested primarily in the state and that other actors are almost powerless. Thus, for McKay, as well as for most Gramscian analysis, power is possessed and vested in the state, rather than relational. Thus, it also helps to reinforce the old Marxist dialectic model by creating binaries of liberal and "other" for all those not defending the liberal order.

If one is to speak of a liberal order, such talk must go beyond the abstract and flimsy world of values and assumptions and hegemonic power that plagues most structuralist discussions. It must focus on power and rationalities of rule and governance. It must reflect the concrete experience of being subjected to the liberal order, not an invocation of values and assumptions divorced from the technologies of power that remade individuals and their communities. McKay's declaration that debates such as

\footnotetext{
${ }^{57}$ As we shall see when we turn to Foucault's analysis, these "tensions" serve an important and strategic purpose for the art of governing.
} 
that between continentalism and the national policy were not fundamental becomes even more confusing when later in his article McKay declares:

From the beginning, this [liberal order] was an inescapably hybrid political project. In the mid-century making of Canada, the signs of 'bargaining with hegemony' were everywhere: a language of politics in which civic humanism, contractualism, and utilitarianism were woven together, often in the speeches of one and the same liberal activist... Such characteristics were not awkward compromises incidental to the liberal project of Canada, but indications of concessions that, in seemingly qualifying the liberal vision. ${ }^{58}$

Nowhere does McKay explain why these activists rernain predominantly liberal when their language reflects such a myriad of other systems of thought and political traditions. This is particularly confusing given his earlier statements concerning the centrality of value systems. Furthermore, if such language implies compromises, who were the compromises with? Who did they benefit and how? In what way did they help to integrate different groups into the national political life? Unfortunately for McKay, these questions cannot be answered by flimsy discussion of values alone. Rather, a relational conception of power must play a central role in any analysis of politics, even one that is interested in understanding the process of "bargaining with hegemony". McKay, it seems, approaches post-structuralism, but turns away out of fear of compromising his Marxist dialectical credentials in advocating the standard poststructuralist de-centred approach, rather than a state-centred one. If the liberal project is truly "qualified" as McKay suggests then certainly debates about the various sociopolitical imaginaries of governance such as the economy, population, society and nation

\footnotetext{
${ }^{58}$ Ibid., 640
} 
are in fact central in understanding how this liberal project was qualified in terms of the power it asserted over the population. His choice of the term "liberal project of rule" is misleading, as what McKay seems to really be focusing on is the state project in Canada, which according to his own linguistic analysis was "inescapably hybrid" rather than liberal. In short, much as the French revolution uses values as symbols for a particular project of rule, McKay's return to values seems to obscure more than it reveals and in its concern with the state sounds more traditionally neo-marxist very typical neo-Marxist in the same vein as the works like those of Reg Whitaker, Leo Panitch and Wallace Clement. Rather than asking questions about the nature of power relations, McKay makes the same decision to rely on the old binaries of the Canadian state and its masters who somehow "possess" power against those who do not have power, as if power was itself a thing as concrete as a fence. According to McKay, liberalism is everything, and consequently has the appearance by the end of his article of being nothing more than a literary trope around which he can craft his tale of "left" history in Canada. While silencing the discourse that is perceived to be dominant may be useful, or even advisable, in the writing of subaltern histories of the type which captivate McKay, the liberal order framework promises a great deal and delivers very little as a conceptual tool for studying the so-called "liberal order." McKay's methodological approach of reconnaissance is also misleading. His strategy is to "study those at the core of this project who articulated its values, and those 'insiders' or 'outsiders' who resisted and, to some extent at least, reshaped it." ${ }^{959}$ Aside from a movement back to the long-toothed neo-Marxist binaries of centre and periphery, what McKay provides is a strategy for writing about ideological resistance to the "liberal

\footnotetext{
${ }^{59}$ Ibid., 621.
} 
order," not about power or how this potential "reshaping" of the liberal order changed the day to day experience of being governed.

What is proposed here is a replacement of the theoretical and methodological approach of the liberal order framework, and the neo-ideological school with an approach that focuses not only on ideas, but rather how ideas exert power and shape practices.

Thus, it requires a movement away from the study of the state as a set of institutions. Rather we will take a de-centred approach that conceives the state as a set of apparatuses, strategies, processes and disciplines with the social, material and biological existence of the population as its main target. ${ }^{60}$ Furthermore, the practices, conduct that reinforce and undermine these multifaceted deployments of force must also be evaluated in order to understand the way in which they responded to the exercise of ideas and power. As Charles Taylor writes:

[Historical] change can come about...through mutations and developments in ideas, including new visions and insights, bringing about alterations, ruptures, reforms, revolutions in practices; and also through drift, change, constriction or flourishing of practices, bringing about the alteration, flourishing, or decline of ideas. ${ }^{61}$

It is with this statement in mind that the utility of different theoretical tools will be examined and brought to bear upon the study of continentalism. This will be done in the hope of developing a new appreciation for continentalism, both its ideas and practices, and their connection to the Ontario political tradition which contains at the very least liberal, tory and civic republican strands. There is much to be done. The relationship

\footnotetext{
${ }^{60}$ Michel Foucault, Security, Territory, Population: Lectures at the College de France, 1977-1978. Michel Snellart (ed.), (London: Palgrave, 2007), 107-108.

${ }^{61}$ Charles Taylor, Sources of the Self: The Making of the Modern Identity, (Cambridge, MA: Harvard University Press, 1989), 205.
} 
between the National Policy and continentalism, at the level of practice or behaviour, has not yet been explored. There has been no in-depth analysis of the continentalist discourse to determine its connection to the major strands of Ontario's political traditions. Nor, has there been any satisfactory exploration of the connection between the discourse of continentalism and the actual formal political practices of continentalism. It is in attempts to answer questions like these that we will turn to the ideas of Michel Foucault on governmentality and counter-conduct.

\section{Theoretical Considerations II: Foucault, Governmentality and Counter-Conduct}

Governmentality was a term coined by Michel Foucault in the lecture series of 1977-1978 at the College de France and expanded in subsequent lecture series.

Governmentality has become an pervasively popular theory for the study of the diffuse process of governance central not only to regulating and normalizing citizens and populations, but also to understanding how freedom relies, at base, upon the exercise of power. There are two specific concepts within the area of governmentality which are of relevance to this study of power and governance in late nineteenth century Ontario: the governmentalization of the state and counter-conduct.

In studying the governmentalization of the state, broadly speaking, we are endeavouring to examine:

...the invention and assembly of a whole array of technologies that connected up calculations and strategies developing in political centres to those thousands of spatially scattered points where the constitutional, fiscal, organizational, and judicial powers of the state connect with endeavours to manage economic life, the health habits of 
the population, the civility of the masses and so forth...it is within the field of governmentality that one sees the continual attempt to define and redefine which aspects of government are within the competence of the state and which are not, what is and what is not political, what is public and what is private, and so forth. ${ }^{62}$

In focusing on continentalism, this thesis is naturally most interested in the state's attempts in the late nineteenth century to manage economic life and the population through this apparatus of the economy. In short, we are most concerned with what Foucault calls biopolitics - the management of the biological functions of any stateconstituted population, in particular, the utility of apparatuses of security, namely economic management, in securing the well-being of these citizens. This kind of state project was central in Canadian politics in the first decades following Confederation as the state sought to solidify its authority as a nation-state - a particular kind of state which gained its legitimacy from the proper and effective maintenance of the national population and its territory. Congruency between these two totalities became the driving force of the modern nation-state. Central to these debates were notions of what was political and what was beyond politics and the consequent competence of the state. Furthermore, as the above statement suggests, this thesis is also concerned with the spatial aspects of the governmentalization of the state. It is concerned with how the management of the population and economy became linked with the problem of establishing territorial sovereignty. ${ }^{63}$

\footnotetext{
${ }^{62}$ Nikolas Rose, Powers of Freedom: Reframing Political Thought, (Cambridge, UK: Cambridge University Press, 1999), 18.

${ }^{63}$ Ibid., 31.
} 
Yet to speak of the governmentalization of the state is not to speak of a smooth and uniform process. Rather, as Nikolas Rose states;

Far from unifying all under a general theory of government, studies undertaken from this perspective draw attention to the heterogeneity of authorities that have attempted to govern conduct, the heterogeneity of strategies, devices, ends sought, the conflicts between them and the ways in which our present has been shaped by such conflict... far from homogenizing discursive space, these studies show how the space of government is always shaped and intersected by other discourses... ${ }^{64}$

What Rose is in part drawing our attention to in the above quotation is Foucault's concept of counter-conduct. Of those themes of interest outlined by Foucault in Security, Territory and Population, counter-conduct is perhaps the least utilized and least understood of Foucault's analytics of governance. Foucault tells us that counter-conduct is simply the "...struggle against the processes implemented for conducting others." Foucault even provides the likely location of these counter-conducts within the state apparatus. According to Foucault, counter-conduct “... will occur on the borders and edges of political institutions." ${ }^{66}$ Freedom, Foucault reminds us, is an "element indispensable to governmentality itself' largely because it allows for the structuring of resistance into more benign aspects of counter-conduct. ${ }^{67}$ For Foucault, these counterconducts of liberal governmentality can be lumped into three categories: i) the opposition of civil society to the state; ii) the opposition of the population to the state; and, iii) the opposition of the nation to the state. ${ }^{68}$ As can be seen by the titles Foucault chooses to

\footnotetext{
${ }^{64}$ Ibid., 21-22.

${ }^{65}$ Foucault, Security, Territory, Population, 201.

${ }^{66}$ Ibid., 198.

${ }^{67}$ Ibid., 353

${ }^{68}$ Ibid., 357.
} 
give them, they do not reject the basic modern organization of spheres of governance within the nation-state, but rather use those categories of organization as a means to mobilize resistance to a particular strategy or tactic of governance. Though not elaborated, within the context of Foucault's own thought, it is possible to categorize these kinds of counter-conduct as three general strategies and tactics in order to establish conduct by others to other ends, not as strategies for undermining the ultimate goal of governing. Counter-conducts seek simply to govern others in different ways, not to dispense with governance altogether.

At this point it may appear as if this analysis is also headed down a state-centred, structuralist approach of my own. In fact, the focus on the state here does not interpret the state as being central at all. Rather, the state happens to be the machination over which continentalists and protectionists are doing battle in this particular narrative. As such, portions of the state enter prominently into this thesis. This does not mean that other sources of authority did not exist. It is quite possible to write a history of counter-conduct within any organization that seeks to control the conduct of conduct. As such, churches, Non-Governmental Organizations, labour unions and corporations, to name but a few examples, are all open to interrogations from this perspective. Rather, as will become apparent in subsequent chapters, several diverse and diffuse sources of authority dialogued with the Macdonaldian project of rule. This project, it must be stated, was not hegemonic, but rather was in the process of struggling for dominance within a particular field of governance, namely the establishment of congruency between the territorial and biopolitical definitions of nation. It sought to ensure that the means of the populations 
subsistence - the economy - coincided with the juridical boundaries of the nation-state. It was a particular project which itself was state-centred. As such, much of the resistance to it took the form of a criticism of the efficacy and legitimacy of the state fulfilling this objective.

In studying continentalism, we are studying not only a discourse which uses the various strategies to undermine the state outlined by Foucault above, but also a movement which emerged from and generated its legitimacy from actual counter-conducts at the very borders of institutions, in this case the Canadian state and the National Policy tariff. Thus, the choice of this theory is justified by the schema it provides for linking discourse and values with action and the impact of each upon the other. The empirical evidence that will be presented throughout this thesis depicts a movement that was both marginal in the sense of its alienation from the existing Macdonaldian order, and central in its refusal to reject the role of political economy as the ultimate tool for directing the conduct of others. Thus, we are dealing with the very thing Foucault had in mind when he came up with the concept of counter-conduct. That is, something which, while opposing the exercise of power and authority in particular fashion or in a particular context (in this case attempts by the state to regulate economic life) is articulated as something firmly rooted in practices and discourses which are part and parcel of the process of the governmentalization of the state.

The response of political parties to the introduction of the National Policy tariff is well documented, but how did individual Ontarians react to the daily imposition of a new apparatus of discipline and security? The tariff schedule is only a tip of the iceberg from 
the perspective of governmentality. Instead, analysis must look at the actual deployment of power by the ministries and individuals responsible for implementing the tariff. Our attention is drawn away from John A. Macdonald and instead, for instance, towards the various Customs Houses that dotted the Canadian border.

Post-structuralist concepts such as governmentality and counter-conduct allow us to investigate how the nearly one-fifth of the Canadian population - most of whom were from Ontario and Quebec - who lived in the United States, responded to the vision embodied in the National Policy: a vision of the Canadian population, society and economy which stopped at the Canadian border. It also allows us to try to analyze the connection between the counter-conduct of the everyday explained in the preceding paragraph and the discourses of counter-conduct put forward by the continentalist intellectuals such as Goldwin Smith, Erastus Wiman and Edward Farrer. Finally, by analysing power from the perspective of strategies, tactics and apparatuses, it can shed light on how the counter-conduct of continentalism was eventually undermined not by an election, but by various actions undertaken by the Liberal-Conservatives and the Liberal party between 1891-1896.

Rather than beginning with the political elite, this thesis will begin with the responses of a myriad of sometimes amorphous individuals to the introduction of a radical new economic policy in 1879 . Chapter two will analyze the initial responses of the people of Ontario to the National Policy; that is, the increase and the changed meaning of smuggling and emigration under the National Policy. Particular focus will be on the exercise of disciplinary power through the National Policy tariff as the chief apparatus of 
the government of populations introduced by the Dominion government. Analysis of the tariff from the perspective of governmentality will show how the tariff sought to remake the meaning of population, economy and society in order to solve the problem of authority inherent in the governance of a "new" nation. It will show how the attempts at incorporating Canada and Ontario through the National Policy were ineffectual and disruptive for the first decade of its operation, thus creating space for the emergence of informal counter-conduct. It was these haphazard moments of resistance that provided a receptive audience to the governmental order proposed by the continentalists which drew upon republican themes in creating legitimacy for its new program of rule.

Chapter three will examine the rich discourse of continentalism to identify and contrast its governmental project with that of the Liberal-Conservative Party. In the end, this line of argument will show that civic republicanism provided the narrative tropes which the continentalist intellectuals drew upon to construct their alternative project of rule. Furthermore, it will examine how this discourse morphed in its dissemination through the Liberal Party press and agricultural publications.

Chapter four will explore the politics of continentalism between 1887 and 1891 with special attention to the Liberal Party's adoption of unrestricted reciprocity at the urging of a loosely-organized, but politically active agrarian movement. The focus will be on practices and performances of continentalism.

Finally, chapter five will trace the demise of continentalism as a counter-conduct through a series of events, strategies and tactics which undermined the movement, including the Macdonald's death, the emergence of a significant loyalty discourse and its 
accompanying moral panic, the abandonment of the movement by the Liberal party at the convention of 1893 and ending with the establishment of the Tariff Commission of 1896 signifying the triumph of the Liberal-Conservative project of territory-population congruency over a more expansive definition of the Canadian nation.

In the end, what will become clear is that, by 1896 , the basic contours of the governmentalization of the state as it related to the management of territory and the daily material conditions of the population had been agreed upon by the Canadian political elite. By 1896 it was evident, that much like Farrer's grave, continentalism would become an object of shame in the narrative of national history - a forgotten belief of another time in need of some dusting off. 


\section{Chapter 2: \\ Informal Counter-Conduct: The National Policy, Smuggling \& Emigration}

Solomon White was an oddity in Ontario politics, especially those of the Conservative variety. White was the son of a Wyandot chief and a Franco-Ontarian mother. ${ }^{69}$ When he married in 1867 and again in 1898 it was not to a fellow native, francophone, or even someone from this side of the Canadian border. Rather his first and second wives were both white American women from Detroit. ${ }^{70}$ Despite White's less than typical story, the Windsor resident found himself politically successful, serving as M.P.P. for Essex North from 1878-1886 and 1890-1894. He was also elected Mayor of Windsor in 1890 running as a continentalist, and later, as Mayor of Cobalt in 1911, shortly before his death. ${ }^{71}$ White made his reputation in politics not so much for the idiosyncrasies of his personal life, but as a strong supporter of French language rights in Ontario, native voting rights and land rights as well as his predilection for annexation to the United States. ${ }^{72}$ His peculiar views on the political destiny of Canada made him as much an embarrassment as an asset for the Conservative establishment. White's unapologetic defence of his views on annexation resulted in his censure on more than one occasion by the party leadership.

Though it goes unmentioned in his entry in the Dictionary of Canadian Biography, Solomon White was also a smuggler. Newspaper clippings and Department of

\footnotetext{
${ }^{69}$ Peter E. Paul Dembski, "Solomon White," The Dictionary of Canadian Biography Online, http://www.biographi.ca/EN/ShowBio.asp?Biold $=41890 \&$ query $=$ solomon\%20AND $\% 20$ White, 5 April 2008.

${ }^{70}$ Ibid.

${ }^{71}$ Ibid.

${ }^{72}$ Ibid.
} 
Agriculture files attest to White's disregard for both the letter and spirit of federal customs law. In October of 1879, a few months after the new National Policy protective tariff had come into effect, White was caught red handed by customs officials attempting to smuggle cattle across the border from Detroit, Michigan. The official seizure notice filled out by William Benson, Collector of Customs at Windsor and the officer who made the seizure, called White's violation "flagrant". ${ }^{73}$

Also included in the file was a newspaper clipping from the Detroit Free Press accusing White of forging a permission form granting him special permission to import the cattle. The form was readily seen to be forged since there was a quarantine on cattle imports from the United States. ${ }^{74}$ The paper concluded that since the introduction of the National Policy tariff of 1879 , smuggling had been on the rise. ${ }^{75}$ The article went so far as to claim that the customs officials at Windsor had recorded 29 seizures on the preceding Monday alone. ${ }^{76}$ Yet the most interesting commentary was that of Mr. William Benson, on the Solomon White case and smuggling in general:

In many cases [of smuggling]...the people are extremely poor and some of the instances are very sad: one case yesterday of a poor woman brought tears to my eyes; but, of course we have no alternative but to enforce the law, and it is not likely that a rich and powerful smuggler is to escape while these poor creatures are punished. ${ }^{77}$

The themes touched upon by Benson - of power and corruption, the material suffering under the National Policy, the uncompassionate rule of law, and the

\footnotetext{
${ }^{73}$ William Benson, Customs Department Seizure Notice \# 122, Department of Agriculture Fonds, RG-17 Vol. 263 File 27236.

${ }^{74}$ Detroit Free Press, Clipping, 22 October 1879, 1 in Department of Agriculture Fonds, RG-17 Vol. 263 File 27236.

${ }^{75}$ Ibid.

${ }^{76}$ Ibid.

${ }^{77}$ Ibid.
} 
dehumanization of the smugglers - were to become recurrent throughout the first decade of the National Policy. Smuggling had been a common feature of Upper Canadian society, a habit well established before confederation and before the introduction of the National Policy. What had changed under the "protective" system established by the National Policy was the discursive positioning of smuggling and trade with the Americans as an activity that went against the national interest. Smuggling became not only illegal, but immoral and unpatriotic for any self-identified Canadian. The new political categorization of what had been a typical part of Canadian material life prompted a variety of informal political responses. As Foucault reminds us, counter-conducts emerge on the borders of institutions as seeming apolitical acts, before they become linked to particular political discourses. ${ }^{78}$ Responses to the National Policy were no exception and followed this general pattern. The smuggling discussed above was one example of a major form of counter-conduct which began in response to the National Policy.

The other major counter-conduct, as the title of this chapter suggests, was the massive emigration of nearly one million Canadians leaving for the United States following the introduction of the National Policy. Upon their arrival on the other side of the line, many of these self-proclaimed Canadian-Americans, created their own hybrid sense of Canadian identity, rather than assimilating to American society. As such, the fully one fifth of the Canadian population living beyond the sovereign jurisdiction of the Canadian nation-state posed a serious impediment to the objective of population-territory congruency.

\footnotetext{
${ }^{78}$ Foucault, Security Territory Population, 198.
} 
As this chapter will argue, the emergence of continentalism as an organized movement in the late 1880 s can be traced back to these seemingly apolitical beginnings in the early 1880 s as everyday resistance to the National Policy. Rather than the traditional depiction of continentalism as a competing ideology which materialized out of an intellectual opposition to the tariff by committed free traders, continentalism may instead be understood first and foremost as a counter-conduct to the National Policy. Hence, Solomon White's herd of illegal bovine immigrants might constitute more than a quick, cross border deal and instead may be seen as a symptom of a broader resistance to a state imposed policy. Similarly, the one million or so Canadians who left for the United States and the subsequent lives they built for themselves as Canadians in those new lands qualifies as another counter-conduct to the National Policy. Hence, these two seemingly apolitical movements are related as they both constitute counter-conducts that inspired the development of the formal continentalism of the likes of Goldwin Smith, Edward Farrer and Erastus Wiman. It is essential to understand how the National Policy was central to creating not only an electorate of potential supporters, but also to creating the proper preconditions - a physical and ideational political space - for the establishment of a counter-conduct of continentalism. In short, the qualitative effects of the tariff on the day to day lives of Canadians and informal resistance to the tariff formed the basis for a discourse of reform linked to a formal counter-conduct which challenged the rhetorical claims made by tariff supporters. It is essential to remember that this was the age of political-economy not pure economics, and as such concerns like efficiency were often secondary to the socio-political implications of economic policy. This was the age of 
explicitly ideological economics, rather than the self-proclaimed "pragmatic" economics

of neo-liberal management.

Yet, in attempting to shed new light, not only on continentalism, but also on the National Policy, it is hard to find furrow that has been left unplowed by the substantial scholarship on the topic and the many constructions of the "National Policy". That is perhaps why, with very few exceptions, historians have remained silent on the topic for the last 25 years. Recent interest in the National Policy has been driven only by attempts to dismiss the National Policy-continentalism debate as interesting, but not essential to understanding Canadian history. ${ }^{79}$

Of the historical writing claiming the National Policy as central to Canadian history, much of it has focused on the importance of the National Policy to the process of nation building in Canada, or on the class conflict the tariff inspired.$^{80} \mathrm{~A}$ third and much more minor group has focused on the origins of the National Policy. ${ }^{81}$ Histories of the National Policy have remained the domain of political historians and economic historians. The rhetoric of these analyses has focused on ex post facto cost-benefit analyses of the policy and political cohesion. The debate has often ranged between those who see the National Policy as a particularly beneficial undertaking for the construction and economic development of a transcontinental nation and the defence thereof; ${ }^{82}$ and a much smaller

\footnotetext{
${ }^{79}$ McKay, Rebels, Reds, Radicals, 58.

${ }^{80}$ As the focus of this thesis is not the history of the National Policy the historiographical section will be appropriately short so as to provide only a basic overview and the issues that emerge from this writing which are central to the thesis. What this section does however hope to indicate is the desperate need for a new history of the National Policy focused on its social impacts and its administrative rationality rather than its rhetoric or results.

${ }^{81}$ Most notably see John Jakub Benjamin Forster, Tariffs and Politics: The Genesis of the National Policy, 1842-1879, (PhD Thesis: University of Toronto, 1982).

${ }^{82}$ See most notably Donald Creighton, John A. Macdonald, (Toronto: Macmillan, 1952-55); R.C. Browne, Canada's National Policy, (Princeton UP: Princeton, NJ, 1964.) \& "The Nationalism of the National Policy" in Peter Russell (ed.), Nationalism in Canada, (McGraw-Hill: Toronto, 1966), 155-163.
} 
group that has suggested that the National Policy was not responsible for Canadian development. Instead, the growth of the Canadian economy was due to longer run trends and external factors leading to the conclusion that the National Policy in fact retarded growth. $^{83}$

As mentioned above, the interest of this thesis is not with the orthodox tensions of this debate. Rather, there is a side-debate attached to these controversies, which is of relevance for the contemplation of how one can approach writing the history of the National Policy. The two sides of the prevailing debate differ on the effects of the National Policy largely because they differ on what the National Policy actually was.

For those who look upon the National Policy favourably, it is simply the "national policy" - an ideological approach to governing Canada. For Brown, and those other historians who embrace the metanarrative of defensive expansionism, the National Policy does not reflect simply the tripartite construction of railways, immigration and tariff protection identified first by H.A. Innis, but rather “...the spirit of the national policy went much deeper than railways, immigrants and tariffs. Beneath these external manifestations was the will to build and maintain a separate Canadian nation on the North American continent." ${ }^{94}$ It was a policy, these analysts argue, that was ideally suited to the materialistic ethos of the age.

Conversely, critics of the National Policy such as J.H. Dales who chose to write the term with capitalization as I have chosen to do above, seek to identify the National Policy in its nineteenth century terms as a protective tariff. Dales contends that the

\footnotetext{
${ }^{83}$ See most notably J.H. Dales, The Protective Tariff in Canada's Development, (University of Toronto Press: Toronto, 1966) \& "Protection, Immigration and Canadian Nationalism", in Peter Russell (ed.), Nationalism in Canada, (McGraw-Hill: Toronto, 1966), 164-177.

${ }^{84}$ R.C. Bown, Canada's National Policy, 11-12.
} 
inclusion of the other "planks" of the National Policy and, even more egregious, its inflation into an ideology, are the fanciful work of the imagination of political historians which ignores the everyday understanding most Canadians held of the National Policy as a protective tariff. ${ }^{85}$

The choice made above in using capitalization throughout the chapter to identify the National Policy identifies this thesis as one favouring the more modest definition of the National Policy as a tariff, no more and no less. Even if the dubious claim that a conception of the National Policy existed which encompassed more than simply a protective tariff that this was the conception of a very few of the ruling elite of Canadian society. The historical record indicates that the vast majority of Canadians understood the National Policy as a tariff, not a tripartite strategy for development and certainly not the official ideology of the Canadian state. ${ }^{86}$ As such, this thesis will operate from Dales' definition with one small, yet important, modification. While Dales has tended to emphasize the macro-economic in evaluating the success or failure of the National Policy, this thesis will take a more organic approach by examining the institutional structure and day-to-day functions of the tariff through the Ministry of Customs and Excise - the ministry responsible for implementing and administering the tariff schedule set by the Finance Department. Also, this thesis will seek to understand popular responses to the National Policy in its first decade of operation. There will be no mention of the number of factories built, or periods of economic boom and bust. ${ }^{87}$ This decision has the added

\footnotetext{
${ }^{85}$ J.H. Dales, "National Policy Myths, Past and Present", 92-94.

${ }^{86}$ To check the validity of this claim it is as simple a scrolling through the letters sent by ordinary Canadians to their politicians. It would seem that while the political elite were aware of the rhetoric of national development much of the population either did not care or was blissfully ignorant.

${ }^{87}$ The late nineteenth century saw many such booms and busts. Rather than seeing these as evidence that the National Policy was working or failing it is important to note that the frequent oscilation between boom
} 
implication that the National Policy will be studied from the perspective of its effect on the day-to-day lives of Canadians as a strategy and tactic of governance. The intent is, as much as possible, to move considerations of the National Policy down from the level of elite rhetoric to the daily lived experience of Canadians.

This thesis argues that the old National Policy controversy in Canada can be revitalized by construing it in terms of attempts to constitute and govern a population, a a social body (nation) and a public (civil society) which was to see itself and be seen as "Canadian". As such, the National Policy is central to the process of governing the Canadian population not only in terms of its economic relationship with outsiders, but also in terms of ensuring congruency between the territory of the state and the spatial location of the population and nation. Our primary interest is how this twofold attempt at governing Canadians led to the emergence of counter-conducts which, in turn, led to the genesis of a politically-assertive, continentalist movement.

The sources for such a history of institutional power and resistance are the departmental circulars, the letters of concern sent to the Department by individual Canadians, and the rhetoric of governance employed by the Department of Customs and Excise, in its efforts to oversee the day- to-day operations of the tariff and ensure its proper administration. Furthermore, not only will the goods smuggled from the United States to Canada be a topic of intense interest, but also the flow of people from Canada to the United States and the meaning such a movement took on for those who participated in

and bust was a sign rather of structural problems within the economy. This is not surprising given that the whole purpose of the National Policy was to control the Canadian economy and restructure its capital and good flows. As such, both boom and bust which characterized the period are the result of the general disruption caused by the National Policy. This disruption will be outlined in detail throughout this chapter. Suffice it to say though that the result was a bifurcation of Canadian economic life between the flows of Canadian economic trade and the state constructed hot-house economy. 
it and those family members who were left behind. It may be noted that these sources were largely catalogued, maintained, and mostly generated by the bureaucratic, journalistic and political elite of society; in some ways, an even greater indictment of the National Policy. As shall soon become clear, criticisms and difficulties associated with the actual daily operations of the tariff are prevalent throughout the official records. If the ministry itself was aware of how problematic the tariff was, it was no doubt quite obvious to many of those who came face to face with the customs house or who crossed the line in hopes of finding greener pastures.

\section{The Minister and His Ministry}

For the moment, Solomon White and his fellow smugglers must be left to the side. If the relationship of the National Policy and the emergence of continentalism is to be understood, it is necessary first to refocus our attention on those men who ran the day-today affairs of the Department of Customs and Excise, rather than on its political creators. Thus, this story of the National Policy is of a different variety. It is a story that does not begin with John A. Macdonald or the business lobby, but rather with the Minister and Deputy Minister of Customs and Excise: Mackenzie Bowell and James Johnston, respectively. Their perspective of the National Policy was not predominantly shaped by the ballot-box, but instead by the day-to-day realities of attempting to make the commercial policy of the Conservative government work, in the face of budgetary shortfalls, administrative incompetence and the limited administrative capacity of an only semi-professional civil service. 
Atop the Department of Customs and Excise stood Mackenzie Bowell. Bowell is perhaps one of the least well-known and least understood of Canada's nineteenth century prime ministers. This is largely due to the very short period in which he occupied the post. Yet, Bowell was an extremely important minister under Macdonald, Abbott, Thompson, and Tilley, acting as the Minister of Customs and Excise from 1878 until the Conservative defeat in the election of 1896 . Despite the 157 volumes of Mackenzie Bowell's private and political papers at the Library and Archives Canada, there is no academic biography of the former prime minister. Bowell was seen by many as a somewhat drab character. Ever the administrator, he was not the kind of politician to offer grand national visions, or celebrated speeches on the issues of the day. Rather, Bowell was an often understated figure who considered himself to be practical above all else. In a response to criticism about the accounting methods of the department in the House of Commons, Bowell once said that:

The Hon. Gentleman is too philosophical and metaphysical for me. I admit that I was not brought up in that particular school [of thought] and I yield the palm to him...in desiring that these positions should be occupied by men of more aristocratic minds and more aristocratic experience. ${ }^{88}$

Bowell's commitment to practicality was developed long before his entrance into Parliament in 1867. Before being elected, Bowell was a pillar of the Belleville, Ontario community. He first worked with his father as a cabinet maker, but soon found himself drawn to the newspaper business where he became a partner in the Belleville Intelligencer in 1848 and had become its sole proprietor by $1850{ }^{89}$ Bowell had also ${ }^{88}$ Mackenzie Bowell, (18 June 1887), House of Commons Debates, Vol. 24, (Ottawa: Queen's Printer, 1887), 1133.

${ }^{89}$ P.B. Waite, "Sir Mackenzie Bowell," The Dictionary of Canadian Biography Online. http://www.biographi.ca/EN/ShowBio.asp?BioId=41353\&query=MacKenzie\%20AND\%20Bowell, 5 April 
turned the paper from a weekly into a successful daily by 1867 and became active in journalism on the national stage as a founding member of the Canadian Press Association..$^{90}$

Bowell's managerial and administrative interests extended well beyond the newspaper business. He was an active officer in the militia up to the 1870 s, mastering the art of military discipline and leadership. ${ }^{91}$ He was a proprietor of several other businesses, a member of the school board and an active member of the Orange Order, being elected grand master for British North America from 1870-1878. ${ }^{92}$ From his perch on the Bay of Quinte, starring across the short expanse of Lake Ontario to the American side, Bowell became intimately connected to the borderlands economy of the young Confederation and its dependence on trade up and down and across the St. Lawrence and Great Lakes into the United States; an economic rhythm that he would eventually be charged with subverting as the architect of the National Policy.

Bowell's "practicality" was not his only ministerial attribute. Bowell was a detailoriented person with a strong affection for organization and structure. He kept detailed and accurate letter books of a private and official nature, as was the nineteenth century business custom. Each correspondence was copied into the letter books before being sent off. Bowell also kept topical item files on issues relevant to the day: files which included clippings, memos and so forth. Where originals could not be found, copies were laboriously made into the book. While in office, Bowell was also a major voice favouring the 1882 Civil Service Act which introduced qualifying examinations aimed at supplanting 2008.

${ }^{90}$ Ibid.

${ }^{91}$ Ibid.

${ }^{92}$ Ibid. 
the naked patronage system with some measure of merit in the making of appointments.

Bowell enjoyed creating and implementing administrative strategies and tactics to achieve his desired ends. He was the principal architect of the administrative apparatus of the National Policy and, consequently, of how it would govern the day-to-day economic conduct of the Canadian population. While Macdonald and Tilley were left the job of defending the National Policy and determining the tariff schedule, it was Bowell's administrative choices that would determine how this tariff schedule would impinge upon the everyday lives of Canadians.

But for all Bowell's administrative strengths he had as many weaknesses. He was an unimaginative though consistent minister. He lacked accommodating vision and was an unforgiving and rigid superior who preferred a paternalistic defence of the letter of the law against any public claims of injustice inflicted by the tariff. When faced with resistance to the National Policy in the North-West, Bowell's response was simple and to the point:

I am quite convinced that the policy of the government in retaining the trade of the North-West as much as possible for the old provinces... is the correct one; and though there may be temporary inconvenience arising therefrom, it will ultimately result in the benefit of the whole... the people of Manitoba appear to me very much like spoilt children. ${ }^{93}$

It was Bowell's administrative personality with all its particularities, strengths and shortcomings that would come to shape the operation of the National Policy, both in terms of his own enforcement of the tariff system and those engagements mediated through his Deputy-Minister James Johnson. Thus, Bowell became the firewall of the National

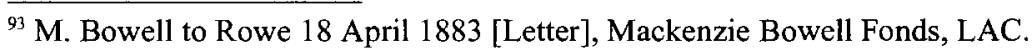


Policy; his attitudes and administrative rigidity supplanted the old informality which had hitherto allowed a loose, casually administered tariff system which sought only revenue, not the re-orientation of Canadian economic life, to co-exist with smuggling all along the Canadian border.

Little is known about Bowell's assistant, James Johnson. From the files which do exist in the Customs and Excise papers at Library and Archives Canada and in Bowell's personal papers, it seems that Johnson and his minister were in agreement over the best way to manage a ministry as complex and important as Customs and Excise - rigidly and diligently. There is no evidence of disagreement between the two. Instead, Johnson behaved as a loyal dog, barking and biting when it would be impolitic for the minister to do so himself. When absenteeism became a problem too big to ignore, it was Johnson who was charged with ensuring that "....in all such cases [of absenteeism collectors must] deduct from the salary of each such absentee the full pay for each day of such absence." 94 It was these two men who plotted the daily course of the National Policy. While Macdonald would often speak eloquently in its defence in terms cloaked with political nationalism, Macdonald rarely interfered in Bowell's activities unless it was an issue of patronage and even then it seems that Bowell was more than able to say no to Sir John without fear of consequence or censure. Smugglers, Macdonald seemed to recognize, were also Conservative voters and he often succumbed to the temptation of allowing politics to trump commercial policy. In the 1884 case of the schooner Andora seized for smuggling, Macdonald pleaded for Bowell to “...have mercy upon the owner of the

\footnotetext{
94 J. Johnson, Circular No. 324-15 30 July 1883, Customs Scrapbook \#2, Customs and Excise Sous-Fonds, Vol. 898. LAC.
} 
schooner and let him off as easily as your conscience will allow."95 Bowell's reply convinced Sir John that the best course of action was actually "...to condemn the vessel and to bring all the parties possible to justice." 96 Bowell got his way and the smugglers were prosecuted. The National Policy was Bowell's show, rarely to be interfered with by anyone from beyond the walls of Customs and Excise.

From Taxation to Protection: The Border and the N.P.

Bowell assumed the position of Minister of Customs and Excise in 1878 with his sole objective of implementing the new National Policy tariff, unveiled early in 1879 . Canadians had lived under tariffs for years up to the development of the National Policy tariff. While the Galt tariff of 1859 created a situation of incidental protection for the Canadian economy, the National Policy represented something new and radical in Canadian politics not because it was a tariff, but because it claimed to be so much more.

Tariffs were understood by Canadians to be a legitimate form of taxation. That is to say, they were the method by which the government could raise revenue to make expenditures. As Bowell himself put it, this accepted rationality, while still pervasive, was no longer of primary concern to the department: "I beg to state that it is not the amount that the government expect to attain that is of any consequence, but it is absolutely necessary that an example should be made... of such wholesale frauds."97 Thus, the National Policy must be understood as a kind of socio-political conditioning

\footnotetext{
${ }^{95}$ J.A. Macdonald to M. Bowell [Letter] 18 July 1884, Mackenzie Bowell Fonds. LAC.

${ }^{96}$ J.A. Macdonald to M. Bowell [Letter] 29 July 1884, Mackenzie Bowell Fonds. LAC.

${ }^{97}$ M. Bowell to P.L. McHally [Letter], 6 January 1881, M. Bowell Fonds, LAC.
} 
aimed at imbuing the population with a sense of belonging to, and forming a part of, the Canadian social body as defined by the juridical boundaries of the state.

This quotation indicates that the National Policy, though, was not a tariff as tax alone, but also - and in some ways contradictorily - a strategy for establishing and governing the Canadian population. It sought to do so in two distinct yet interconnected ways. The tariff was to become both the border and a tool in regulating the day-to-day material relationships between members of the population.

Turning first to the tariff as border, evidence of a new rationality regarding the tariff is everywhere in speeches. That the National Policy is about sovereignty should come as nothing new, as traditionally the National Policy has been linked by historians of the Laurentian school to what they have identified as a rationality of defensive expansionism. This chapter argues that the National Policy invested the border with a new, more rigorous administrative reality, making it a central feature of the definition of Canadianness.

It is all too easy to look at a map and assume that borders somehow exist. Certainly maps are central to creating borders discursively, and act to some degree as a technology for teaching the population to see the border as real. Yet, once a map is folded up, the border simply melts into the creases. It becomes a kind of border which is easily forgettable as one pulls a sleigh across the winter ice of the upper St. Lawrence to the other side of the "line". While this line was guarded in places or at points by military and police units, their objective was to maintain the territorial integrity of the state, to manage threats form outside and sometimes to expel threats from within. While the map sketched 
the border in the minds of Ontarians, it was the police and military apparatus that inscribed this line in their movements and in the physical space around them. Yet, even the military and police apparatus ensured the border was visible only when one chose to transgress it. The border also intruded into Ontarians' daily life in terms of communication - postal and telegraph services - but here again it was an arm's-length relationship.

The National Policy was designed to make the border present in the daily lives of those who never went near the frontier with the United States. Ideally, it would make the border visible in the price of goods and in the individuals with whom Canadians were able to engage in economic transactions. In short, it would incorporate Canada into a nation by making the border visible everywhere to everyone at all times; everywhere Ontarians and other Canadians would be made to feel that the frontier was all around, binding them as one people. Its goal was to create what literary critic Northrop Frye would describe as a kind of "garrison mentality".98 As Bowell eloquently put it in 1883:

A national protective policy means the encouragement of all industries in all sections of the country, and situated as we are, with our diversified interests extending from the Atlantic to the Pacific, we must learn this important fact, that if we desire to prosper and become a great people we must have sufficient forethought and breadth of intellect to learn to "give and take;"... [it is not the objective of this policy]...to give it [Canada] over to the Yankees... [or] to build up this country for the benefit of our neighbours. ${ }^{99}$

The last three lines are especially significant as they imply that to behave counter to the policy, to refuse to "give and take" materially is to deny the existence of Canada; to

\footnotetext{
${ }^{98}$ See Northrop Frye, "Conclusion to a Literary History of Canada." The Bush Garden: Essays on the Canadian Imagination. (Toronto: Anansi, 1975).

${ }^{99} \mathrm{M}$. Bowell to Rowe [Letter] 18 April 1883, Mackenzie Bowell Fonds, LAC.
} 
behave in such a way as symbolically to cross over the line to the United States and to surrender to behaviours that were antithetical to Macdonald's national vision. Solomon White's smuggled herd was by this definition not just a defiance of the letter of the law, but also an act that defied national aspirations.

Later, Bowell would strengthen his claim that to question the N.P. and its construction of the border amounted to a denial of Canada:

If the National Policy has not accomplished all for Canada that it might, it is because of the uncertainty that has accompanied it...Let the people by their coming vote determine that whatever may be their opinion upon other matters the future rulers must, above all things, be Canadians with a Canadian policy and no man will have course to complain what that policy will do. ${ }^{100}$

The policy then became synonymous - both administratively and metaphysically with the boundaries of Canada itself. To deny the National Policy's cartography, in the mind of Bowell and other Liberal-Conservative administrators, was to deny the presence of Canada as a nation.

A primary objective of the National Policy was to establish the border as a customs line. Through its control of the price of goods, the National Policy could extend its power and consequently the legitimacy of the state and its protectionist definition of the nation from the customs house back into the hinterland of the country. ${ }^{101}$

As Foucault reminds us, the ascendant governmental regime that began in the eighteenth century relied heavily upon the establishing of sovereignty not just over

\footnotetext{
${ }^{100}$ M. Bowell [Speech], n.d. (1890?) Mackenzie Bowell Fonds. LAC.

${ }^{101}$ Though beyond the time period of this thesis, it is noteworthy that others studying the border around the turn of the century have identified that the border was seen by administrators in the Canadian state as a customs line. See James Macdonald, A Genealogy of the Undefended Border: Denaturalizing current conceptions of the Canada-U.S. border through the use of Foucault's concepts of Genealogy and Governmentality. (Ottawa: Carleton University, M.A. Thesis, 2003).
} 
territory, as has been discussed above, but also over the population. The National Policy also looked to manage the population by tracking its movements across the border, and more importantly, by governing its material relations internally and with other populations, particularly that of the United States, in order to ensure congruency between the boundaries of nation, the activities of the population and the territorial jurisdiction of the state. Market statistics as well as the tariff schedule became central technologies of power in the implementation of this second and related objective of the National Policy: to make visible and manage the socio-economic relationships of the Canadian population.

Just as the census sought to accumulate information on the vital statistics of population to make it visible and open to biopolitical management, ${ }^{102}$ the National Policy - in some ways a rational consequence of the emergence of statistical knowledge - used the accumulation of economic statistics in order to make visible the daily material and social existence of the population. The tariff schedule and customs house were central to this endeavour. In the Library and Archives of Canada, tariff schedules are retained from the years 1877-1893. An examination of these schedules put to use by customs officials in applying the tariff shows the increasing complexity and invasiveness of the National Policy as it sought to gain more knowledge of the material life of Canadian society.

The tariff schedule from 1877 was a thin volume, and represents the last volume produced before the introduction of the National Policy. Included in the thin volume of a mere 20 pages were a handful of specific duties; the goods that were charged the standard revenue tariff rates of $5 \%, 10 \%$, and $25 \%$ took up only two pages and a list of free goods

\footnotetext{
${ }^{102}$ Bruce Curtis, The Politics of Population: State Formation, Statistics and the Census of Canada, 1840 1875, (Toronto: University of Toronto Press, 2002), 306.
} 
extended for six pages. The goods listed were general, such as "iron" or "books or "semifinished goods." 103 All in all, the tariff schedule of 1877 has the appearance of a reference book designed to aid customs officials in making decisions regarding imports. There was little to recommend the pre-National Policy tariff as a strategy for managing the economic life of Canadians. Rather, as the schedule reveals, the pre-National Policy tariff was only interested in generating sufficient revenue to allow the state to meet its financial obligations.

Only a year later, with the introduction of the National Policy, the book had doubled in length. ${ }^{104}$ The detailed vision of Tilley and Bowell is present in the earliest volume where different duties begin to be specified for products as similar as billiard tables with or without pockets or for coco-paste, sweetened or unsweetened. ${ }^{105}$ Perhaps the most significant development for our purposes was the introduction of differential duties based on the intended use of imports. Cordage for ships was dutiable at $10 \%$ while cordage for any other purpose was dutiable at $20 \%$. While this does reflect an attempt to stimulate ship building, it also indicates an attempt on the part of the state to measure and regulate how goods were being used by the population. To this end, all entries of goods were recorded in books and submitted to the Department complete with folding instructions for the accompanying invoices. ${ }^{106}$

${ }^{103}$ Customs and Excise, Vol. 808 RG 16 A-3 Tariff or Customs of the Dominion of Canada, Feb. 20, 1877, LAC. 8-9

${ }^{104}$ Customs and Excise, Tariff or Customs of the Dominion of Canada, 1878. Customs and Excise Fonds, RG 16 A-3.

${ }^{105}$ Ibid. 6 \& 8.

${ }^{106}$ J. Johnson, Circular 328-19, 15 October 1883. Customs and Excise Fonds (Customs Scrapbook \#2) Vol. 898. LAC. 
Subsequent issues of the tariff schedule contained more and more details of goods and a more complex tariff schedule. It is important to remember that, along with the tariff schedule, memos and circulars were issued by James Johnson on behalf of Bowell constantly changing duties to make them more complex and allow for the division of material goods into more specific categories based on size, composition, type and end use of the good. The tariff had become, at least in intent if not in practice, a precise instrument for state measurement and regulation of the economy. An order in council of 25 May 1883 is a fine example of the new tariff rationality: "Hoop iron not exceeding three eighths of an inch in width and being No. 25 gauge or thinner, used for the manufacture of tubular rivets," was declared duty free. ${ }^{107}$ At times, memos, circulars and orders in council were used to assist customs officials in employing various tests to determine the quality or type of good being imported. In 1883, Coal dust had to be defined as “...such screening or fine coal as is capable of being passed through a screen the meshes of which do not exceed one-half inch in diameter." 108 In 1882, customs officials were instructed to stir a sample of the good into water in order to distinguish between yellow cotton seed foot grease and soft soap. ${ }^{109}$ The management of such a complex tariff schedule required a rigid commitment to empiricism on the part of customs officials. Instruments of measurement, quick experimentation, and sensory observation became central techniques for implementing the tariff. The border had become a strategy of governance which utilized various disciplinary technologies to move beyond the

\footnotetext{
${ }^{107}$ Minister of Customs and Excise, Order in Council 25 May 1883, Customs and Excise Fonds (Customs Scrapbook \#2) Vol. 898. LAC.

${ }^{108}$ J. Johnson, Memo 96, 11 June 1883, Customs and Excise Fonds (Customs Scrapbook \#2) Vol. 898. LAC. ${ }^{109}$ J. Johnson, Memo 6526 Dec. 1882, Customs and Excise Fonds (Customs Scrapbook \#2) Vol. 898. LAC.
} 
rationality of revenue that prevailed in 1877 to invest the concept of Canadian with a new and more rigid meaning.

The new tariff regime demanded not just rigourous enforcement, but also necessitated new methodologies of determining the value of imported goods. To this end a new pricing regime was introduced for imported goods. Under the pre-National Policy tariff, duties had been charged ad valorem on imports based on the price stated on the invoice. Partly as an attempt to reduce fraudulent invoices that understated the actual value paid for goods, and partly to extend scientific management to pricing, the new regime was based on the awkward concept of "fair market value".

Fair market value was defined as the price that the good would fetch in its home market for consumption there. In effect this meant that the value of a hammer, for example, was not necessarily how much the Canadian importer was charged for the good, but rather how much a hardware store owner in the United States would pay for the hammer were he buying it for resale in the United States. Thus, the prices printed on invoices were no longer taken to reflect the true value of goods. Instead, the Department of Customs and Excise relied upon disclosures from foreign businesses regarding their prices as well as investigation by their officers. Not surprisingly, determining the fair market price of goods proved much more difficult in practice than in theory.

The problems with this system of valuing imported goods were substantial. As one revealing memo from Johnson to the Port Hope collector of customs attests: "I beg to state that it is impossible for me to give you prices of locomotives as they have been 
fluctuating for some time..." ${ }^{110}$ Common changes in prices that were detected were sent on the Customs Houses through memos. However, sometimes the changes in price were not clear and customs officers were left on their own to determine if a good was "undervalued" or not. ${ }^{11}$ When Bowell and the government were accused of "immorality" in the affairs of trade Bowell responded by declaring that;

There is but one law to guide customs officers, and that is to charge duty apon [sic] the fair market value of the article in the country in which it was purchased, when used there for home consumption...All the government desires to do is to place every importer on an equality. It matters not to the customs what you pay for the goods, or whether they are given to you. ${ }^{112}$

Thus, the pricing regime that came into effect with the National Policy was aimed at reinforcing the modern art of government by establishing a uniformity and regularity of conduct on the part of Canadians engaged in imports and by extension their clients. As the last sentence above indicates, the pricing regime aimed to ignore the realities of economic activity and market based pricing and instead aimed at establishing an abstract and fanciful pricing regime defined by non-Canadian markets. It sought to eradicate market-responsive pricing in favour of a politically-created, predictable and stable calibration of prices. Economic behaviour as conceived by the new pricing regime of the National Policy was rooted in idealism rather than market realities. The effect of this pricing based on other markets was to highlight the "otherness" of imported goods. The "true" price was hidden rather than manifest in the invoice, unlike Canadian made goods

\footnotetext{
11024 March 1883 J. Johnson to Port Hope Collector of Customs, Customs and Excise Fonds (Port Hope Received letters), RG-16 A-2 Vol. 607. LAC.

${ }^{11 \prime}$ J. Johnson, Memo No. 78, 15 March 1883. Customs and Excise Fonds (Customs Scrapbook \#2) Vol. 898. LAC.

${ }^{112}$ M. Bowell to Cuthbert [Letter] 5 December 1882, Mackenzie Bowell Fonds, LAC.
} 
where the price was the invoice price. As such, products that were imported became foreign and untrustworthy due to the assumption that the price they were sold to Canadians for were not reflective of "reality" or "fairness".

Bowell and Johnson were uncompromising in the commitment to the detail they expected from customs officials. In September of 1882, Johnson complained of “...a gross slovenliness and carelessness of filling and examination of invoices...it would appear...that they [the memoranda and circulars] must be thrown aside almost without perusal, certainly without careful consideration," at the customs house in Fort Erie. ${ }^{113}$ The problem was not localized, nor did it subside. Three years later, a memo written to Bowell in 1885 by the department regarding the "Cost of the Inside Service" - the branch of Customs and Excise responsible for monitoring and ensuring uniformity between all customs houses - complained that “...the volume of work has greatly increased, and the tariff has gradually grown more complex and difficult to administer, requiring a more intelligent and better equipped staff than was necessary under the [comparatively simple] Tariff of Reform days."114

The complexity of the National Policy created more than just administrative headaches for Mackenzie Bowell and Johnson. The effect of such complexity was felt more acutely by those Canadians who sought to engage in any economic activity outside the Canadian market. As economist J.H. Dales has pointed out, these exporters and importers became a wider and wider group of individuals as trade increased with the

\footnotetext{
${ }^{113}$ J. Jhonson to T.C. Mewburn Letter, RG-16 Vol. 469 pt. 2 Fort erie Collectors correspondence 1881-1891. ${ }^{114}$ J. Johnson, Memo Cost of Inside Service 1885, Mackenzie Bowell Fonds, Vol. 98 File 6.
} 
United States in spite of the high tariffs. ${ }^{115}$ The confusion accompanying the tariff affected those importing goods or purchasing goods in many ways.

A common complaint was that incorrect duties were applied to imported goods, or that different ports often charged different rates of duty. These errors were typically the result of the complexity of the system in place and the volume of information confronting Customs Officers. Johnson complained that " $[\mathrm{t}]$ his department is continually harassed by quotations in letters from collectors... from the above circular [224-10 of 9 July 1879] which they appear to think overrides the tariff changes adopted by parliament."116 On 28 April 1881, Johnson complained to Mr. Burton, the Collector of Customs at Port Hope, that the customs house was charging the wrong duty. ${ }^{117}$ On 17 June 1884 , a further letter to Burton pointed out his failure to collect duties on manufactured goods, goods which he subsequently entered as duty free. ${ }^{118}$ These problems did not go unnoticed by the general population. J.J. Reemer, in a letter of 19 December 1885, complained of differing duties on sugar being charged at different ports. ${ }^{119}$ Such incompetence and inconsistency tended to reduce the legitimacy of the National Policy.

General confusion, as well as what would seem to be a lapse in supervision, also created delays for some at the customs house. Circular 241-6 of the 25 of February 1880 reminded customs officials that the custom house was to be opened no later than $9 \mathrm{am} .{ }^{120}$ The implication was not only that customs officials were failing to open the customs

\footnotetext{
${ }^{115}$ Dales, "National Policy Myths, Past and Present," 92-94

${ }^{116}$ J. Johnson, Memo 94, 8 June 1883, Customs and Excise Fonds (Customs Scrapbook \#2) Vol. 898. LAC.

117 J. Johnson to Burton [Letter], 28 April 1881, Customs and Excise Fonds, RG-16 A-2 (Vol. 697 Port Hope Received letters), LAC.

${ }^{118}$ J. Johnson to Burton [Letter], 17 June 1884, Customs and Excise Fonds, RG-16 A-2 (Vol. 697 Port Hope Received letters), LAC.

${ }^{119}$ Reemer to McLean [Letter], 19 December 1885, Mackenzie Bowell Fonds, LAC.

${ }^{120}$ J. Johnson, Circular 241-6, 25 February 1880, Customs and Excise Fonds, RG-19 E-4-5 Vol. 3719. LAC.
} 
houses on time, but that customs houses, and consequently the border, ceased to exist during the night! $!^{121}$ Thus, despite the rigid administration found during daylight hours, the National Policy failed to assert itself when the sun went down. This no doubt seriously undermined its efficacy and legitimacy when all a would-be smuggler need do was wait until after dark.

The tariff further invaded the lives of the people of Ontario and Canada in other important ways. Bowell created the Special Agents Branch in 1880, which was responsible for policing the areas away from the customs house to detect frauds that had escaped the front line officials. They were often busy, as a circular of 1886 commented that "Numerous seizures have been made by officers of the Special Agents Branch... which with other evidence in the possession of the department goes to show that great laxity exists on the part of collectors and other customs officers." ${ }^{922}$ Faced with a completely unworkable system and either too much or too little information, customs houses were apt to simply "laissez-faire; laissez-passer" in cases that were not obvious.

This kind of covert surveillance of trade coupled with gross administrative shortcomings and inconsistencies was at once more invasive, more disruptive, and just as easily circumvented as what had come before. It projected the power of the Customs House back from the frontier and to the shop window of the local store in an almost arbitrary manner. The tariff had thus become an intrusive feature of Canadian social and economic life; ever present, but in an inconsistent and unpredictable fashion.

\footnotetext{
$\overline{121}$ U.S. Customs to Bowell [Letter] 14 October 1880. Mackenzie Bowell Fonds, LAC.

${ }_{122}$ J. Johnson, Circular 373, 14 August 1886, Customs and Excise Fonds. (Customs Scrapbook \#2) Vol. 898. LAC.
} 
The National Policy, along with its expected punishments of heavy fines and imprisonment, also placed the burden of proof upon the importer rather than the state. If the importer disagreed with the decisions of Customs officials, trials could get expensive. Given that, as the Collector of Customs at Windsor testified above, that it was often the poorer members of society who were guilty of customs fraud, such appeals were rare. ${ }^{123}$

Cumulatively, the National Policy was not just another tariff, but rather a completely new strategy for managing the population through both the exercise of techniques of sovereignty through the establishment of a centralized fiscal power economic border and also through techniques of security and discipline in the management of material interaction within the population. The National Policy aimed greatly to reduce the old porosity of the border. It sought to problematize and criminalize many forms of economic and social behaviour that reflected a continental rather than nationalist bent through its rhetoric and its political rationality. Yet, the exploration of how certain behaviours were problematized in speech and within the administrative structure of the National Policy does not in itself explain how the people of Ontario reacted to this new rationality.

While the foregoing analysis of the National Policy in terms of the aspirations of its creators is useful for helping us to pin down the administrative rationality of the tariff and the expectations of those in charge of the National Policy had of both their staff and the Canadian population, it does not help us to understand how individuals experienced the National Policy on a daily basis, or how it impinged upon their sense of the relationship between economic life and citizenship. Rather, our attention must now turn

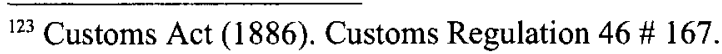


towards how this administrative rationality and these expectations were put into action, and resisted on a daily basis. As such, our gaze will move from the ministry headquarters in Ottawa to the customs houses that dotted the Ontario-America frontier. It is here that it will become increasingly apparent how the above rationalities and strategies fostered the development of a counter-conduct to the National Policy. On the surface the National Policy looked impressive, but in the context of its everyday management, one could not help but wonder if it was in part the inspiration behind the classic Monty Python sketch about the "Ministry of Silly Walks."

\section{The Counter-Conduct of Smuggling}

One of the most obvious forms of resistance to the National Policy was the act of smuggling. Smuggling was conducted in many ways, from sneaking across the border for which Solomon White provides an excellent example - to more sophisticated tactics such as the undervaluing of goods on invoices, to the misrepresentation of the kind, or amount of a good being imported. Smuggling was a complex activity and, as the evidence below will demonstrate, from the very beginning it was a continental effort.

Solomon White's attempt to avoid customs by sneaking cows across the border was not uncommon. However, it is nearly impossible to guess exactly how common this simple kind of smuggling was, as it most likely happened at night or away from ports of entry when the Customs Houses were closed or absent to avoid the notice of officials. Furthermore, statistical records and methodologies are notoriously imprecise in gauging this kind of behaviour. 
Nonetheless, well-documented cases of smuggling include those using tactics like undervaluation. Undervaluation is interesting in that it required the participation of the merchant selling the wares either in the United States or elsewhere. It worked by having the seller draw up a faulty invoice for the benefit of the customs officials which would price the good well below what it was actually sold for, allowing those importing goods into Canada to pay a much reduced duty. H.D. Thatcher and Co. of Potsdam, New York, for instance, was in the habit of sending blank invoices along with their goods so that the importer could simply enter the price they wished to pay at customs. ${ }^{124}$ H.D. Thatcher and Co. was not alone as memos were issued frequently by the Customs department identifying such practices undertaken by manufacturers at Boston and Detroit as well. ${ }^{125}$ The approach was typically used by W.H. Pepper from Lake Village, New Hampshire, who would write to one of his Canadian customers: "You will see I have made $10 \%$ off from $\$ 125.00$. My price in the States is $\$ 130.00$." Consequently, the machine was invoiced for import at $\$ 112.50 .{ }^{126}$ How this letter and others like it came into the hands of the Customs Officials is not clear, but it at least implies a substantial degree of surveillance that went so far as to access the private correspondences of individuals. Colgate \& Co. of New York had the process down to a science. They used two price lists, one for domestic purchases and one for export purchases in foreign markets which offered a reduced rate. Furthermore, any orders of $\$ 500.00$ or more were given an additional $25 \%$ discount and at other times free "gifts" were included with the order and excluded

\footnotetext{
${ }_{124}$ J. JohnsonMemo No. 57, 7 Nov. 1882. Customs and Excise Fonds. (Customs Scrapbook \#2) Vol. 898. LAC.

${ }_{125}$ J. Johnson, Memo No. 814 April 1883. Customs and Excise Fonds. (Customs Scrapbook \#2) Vol. 898. LAC

${ }^{126}$ J. Johnson Memo No. 84. 17 Apirl 1883. Customs and Excise Fonds. (Customs Scrapbook \#2) Vol. 898. LAC.
} 
from the invoice. ${ }^{127}$ The Colgate example is particularly interesting, as under the old tariff regime, as would be the case today, this would be understood as a competitive pricing tactic and as efforts to stimulate bulk ordering. Yet under the tariff regime of the National Policy, these business practices were deemed illegal.

Another related approach was to misrepresent the contents of packages. With differential duties being assigned to goods based on the appearance, or stated use of products under the National Policy, it was easy for manufacturers to avoid the tariff by claiming that goods were of another type or for another purpose and thereby receive a lighter duty. Sherwood Harness Co. of Syracuse New York, for instance, was in the habit of shipping harnesses as horse yokes in order to receive a lesser rate of duty on the product. ${ }^{128}$ Coated cloth was commonly entered as patent leather in order to take advantage of the lesser rate of duty on the later. ${ }^{129}$

A less common but equally sophisticated tactic involved changing the name of the product for export in order to claim that the different price was a result of a different quality of product, and thus to conceal the process of undervaluation. ${ }^{130}$ An approach common among British manufacturers was to misrepresent delivery costs as a portion of the price in order to enter the good at a lower rate. ${ }^{131}$

\footnotetext{
${ }^{127}$ J. Johnson, Memo No. 124. 23 August 1883. Customs and Excise Fonds. (Customs Scrapbook \#2) Vol. 898. LAC

${ }^{128}$ J. Johnson, Memo No. 466, 7 October 1885. Customs and Excise Fonds. (Customs Scrapbook \#2) Vol. 898. LAC.

${ }^{129}$ J. Johnson, Memo 417, 15 June 1885. Customs and Excise Fonds. (Customs Scrapbook \#2) Vol. 898. LAC.

${ }^{130}$ J. Johnson, Circular 332-2, 7 Jan 1884. Customs and Excise Fonds. (Customs Scrapbook \#2) Vol. 898. LAC.

${ }^{131}$ J. Johnson, Memo No. 50, 9 Oct 1882. Customs and Excise Fonds. (Customs Scrapbook \#2) Vol. 898. LAC.
} 
This illicit trade tended to drift towards the spots where the border was most porous and supervision was lax. If Bowell is to be believed, it was in small communities, particularly those who had their own "outport" - a subsidiary customs house - where smuggling was most rampant. As late as 13 January, 1887 Bowell declared that, “...the opening of these small ports tends to increase smuggling, from the fact that the parties appointed are not paid sufficient to enable them to give their whole attention to Customs business." 132 Smugglers, thus, appear to have worked out their own strategies and tactics to counter the customs wall of the National Policy.

The continuation and escalation of smuggling came despite attempts by the department at deterrence by increasing penalties in cases of fraudulent invoices and by requiring multiple copies and more detailed invoices from importers. ${ }^{133}$ Bowell's frustration with the continued prevalence of smuggling under the National Policy was acute:

I have come to the conclusion that the people living on the frontier [with the United States] are in their views of the customs laws very much like boys at a certain age when they visit their neighbours orchards and melon patches, think it no harm to smuggle or steal fruit. ${ }^{134}$

The National Policy aimed to vilify those who bucked its rationality as unpatriotic. Bowell's frustration was only increased by the extra-legal status of smuggling amongst the general population: "I do not understand how men who in any other vocation of life

\footnotetext{
${ }^{132} \mathrm{M}$. Bowell to Cochrane [Letter] 13 January 1887. Mackenzie Bowell Fonds. LAC.

${ }^{133}$ J. Johnson, Circular 327-10, 12 June 1883. Customs and Excise Fonds. (Customs Scrapbook \#2) Vol. 898. LAC.

${ }^{134}$ M. Bowell to Scriver [Letter], 7 November 1882, Mackezie Bowell Papers. LAC.
} 
would shudder at the thought of declaring falsely... would swallow a libellous oath [regarding customs declarations] without the slightest qualm of conscience."135

Bowell's quote captures the degree to which he was aware that smuggling, despite its forbidden nature under the National Policy, had taken on the appearance of being a kind of informal resistance to the Conservative policy. This view was not held by Bowell alone. Liberal papers were all too happy to link what they perceived as a great increase in smuggling to the introduction of the National Policy.

As early as 1876, following Macdonald's National Policy speech, the Globe launched an attack on the introduction of what it called a "hostile tariff". The article argued that the introduction of the National Policy would result in a situation where "... there would be no legitimate commercial intercourse, with, consequentially, no Customs' revenue, but universal smuggling and general demoralization." ${ }^{136}$ With the Liberal papers' melodramatic warnings going unheeded, the dire predictions and interpretations of smuggling behaviour only intensified after the introduction of the National Policy in 1879. The Globe staff repeatedly referred to the National Policy as "... an unmitigated robbery and fraud..." insinuating that to violate the tariff was the same as resisting criminal behaviour. ${ }^{137}$ Briefs were common such as those of 5 and 29 of November 1879 which declared that "...smuggling is very prevalent in the Maritime Provinces," and that "[a] great deal of smuggling is carried out along the New Brunswick border,"

\footnotetext{
${ }^{135}$ M. Bowell to Carling [Letter] April 5, 1881. Mackenzie Bowell Fonds. LAC.

${ }^{136}$ Globe, 13 March 1876, 2.

${ }^{137}$ Globe, 26 March 1879, 2.
} 
respectively. ${ }^{138}$ This, of course, was because high tariffs like the National Policy “... offered great inducements to smugglers." 139

As the 1880s proceeded, the Globe became more bold: "Smuggling is looked upon by the feminine part of the community as...the evasion of an unjust law."140 A law which was implied to be unjust because of increased price of subsistence. On one occasion the Globe uncovered a story at Kingston of Landing Waiter Murphy and Preventive Officer Briggs participating in smuggling rings. ${ }^{141}$ Throughout the 1880 s and 1890 s the Globe jumped at every opportunity to show the "immoral" effect of the National Policy on economic life through its promotion of smuggling: "With such a frontier as ours it must be impossible to prevent smuggling altogether, but smuggling never was carried on so openly and extensively as it has been since the present high tariff went into operation."142 Comments like the above small selection served only to legitimize and formalize the behaviour of smuggling as a legitimate way of expressing displeasure with the National Policy. Yet the narrative common to all these places was one of nostalgia for the revenue tariff of the pre-National Policy period, rather than an endorsement of a continentalist solution. However, the Globe's decision to hold the Conservatives responsible for smuggling rather than placing responsibility on individuals to adhere to the Custom's law created a new space in which alternative visions of Canadian economic life could be articulated; a discursive space that continentalism would soon occupy, along with ideas like imperial federation.

\footnotetext{
${ }^{138}$ Globe, 5 November 1879,3 \& 29 November 1879,1

${ }^{139}$ Globe, 5 December 1879, 2.

${ }^{140}$ Globe, 16 July 1880,3 .

${ }^{141}$ Globe, 4 November 1881, 7.

${ }^{142}$ Globe, 11 August 1883, 8.
} 


\section{The Counter-Conduct of Emigration}

While much of the above discussion has centred around smuggling, there is another response to the National Policy which falls under the definition of counterconduct. While smuggling challenged the economic claims of the National Policy for managing the material well-being of the population, it was migration that challenged the claims of the National Policy that the border was congruent with the boundaries of the nation. As many as 2.5 million Canadians between 1860 and 1900 pored across the border to the United States. ${ }^{143}$ While this exodus was substantial, it became an absolute flood with somewhere between 1.2 and 1.5 million Canadians leaving for the United States between 1878 and $1896 .{ }^{144}$ Bowell unofficially took notice of this phenomenon in a few quiet requests to his collectors of customs asking for numbers on those who had emigrated from Ontario. Dail Fergusson's letter from the Chatham Customs House identified 12 people who had left. Yet in reading further, excluded from his official numbers were the 100 labourers, 30 servant women and 35 "girls" who had also departed for the greener fields of the republic! ${ }^{145}$ Often times the Customs officials were clueless as to the movement of individuals across the border. After 1880, the documentary evidence suggests that Bowell simply stopped inquiring as to the numbers of individuals quitting Canada, and Ontario in particular, for the United States. Many of these

\footnotetext{
${ }^{143}$ Randy William Widdis, With Scarcely a Ripple: Anglo Canadian Migration to the United States and Western Canada, 1880-1920. (Montreal: McGill-Queen's University Press, 1998), 3. ${ }^{144}$ Ibid., 64-65.

${ }^{145}$ Fergusson to Bowell [Letter], 17 Nov. 1880. Mackenzie Bowell Fonds. LAC.
} 
departures were from the rural areas of eastern and south-western Ontario, the future heartland of continentalism. ${ }^{146}$

In challenging the claims of the National Policy to define the spatial limits of Canadianess, it undermined the political authority of the Dominion government first implicitly, and, as we shall see in our forthcoming examination of the activities of this expatriot community, it also came actively and explicitly to undermine the Dominion government's definition of Canadianess.

The existence of a Canadian expatriate community in the United States was nothing new in the $1880 \mathrm{~s}$. As has been shown above, migration was a common feature of relations between the two countries. What was different about the 1880 s was the escalating volume of young Canadians seeking homes in the United States and the way that experience was narrated by the migrants. In an attempt to capture this initial counterconduct our attention will now turn towards two interrelated spaces where the experiences of being a "Canadian-American" was articulated and made manifest.

The first such space was the columns of the newspaper the Canadian-American. The Canadian-American began publishing in 1882 and survived for more than 20 years as a source of information on the comings and goings of Canadians who lived "across the line." 147 The paper was edited and published by the Jaffray brothers simultaneously from offices in Chicago and Minneapolis. Furthermore, the paper had an office in New York in order to stay abreast of the active Canadian-American population there. ${ }^{148}$ No circulation statistics survive, but some announcements contained within the paper show that some

\footnotetext{
${ }^{146}$ Widdis, 64-67.

${ }^{147}$ The Canadian-American, 9 March 1888, Vol. 6, Iss. 259.

${ }^{148}$ Ibid.
} 
3,000 subscribers were in arrears in 1890 , yet the paper still had sufficient income to continue publishing in its weekly form for more than a decade, suggesting that its readership was substantial amongst ex-patriots. ${ }^{149}$ Though no early issues survive, a nearly complete run of the paper exists from 1890-1891, a limited selection of issues survive from 1892-1894, and a small number of issues from the early twentieth century are also available.

The paper was consistent in following several themes throughout the years of its publication. Along with highlighting the activities of notable Canadian-Americans such as the New York financier Erastus Wiman, the paper also kept tabs on the activities of more modest members of the Canadian population in the United States. Similarly, the paper followed events in Canada, especially politics, being sure to compare and contrast Canadian policy and politics with American wherever possible. Also, and perhaps most significantly, the paper contested the border by emphasizing not only its fictitious nature, but also, the similarities between Canadians and Americans.

In its survey of the activities of Canadian-Americans, the paper relied on several tropes in order to construct a sense of cohesion among the group. One trope which was applied in many of the stories was the increased personal success and prosperity experienced by Canadians who came to live in the great Republic. In this vein, Erastus Wiman was a favoured topic of discussion in the paper. Wiman, having made a name for himself at the credit rating agency of R.G. Dunn \& Co. in Montreal, had moved to the New York office where he subsequently became involved with the Union Telegraph

${ }^{149}$ The Canadian-American, 28 February 1890, Vol. 7, Iss. 351. 
Company and in the development of Staten Island. ${ }^{150}$ The paper loved to remark upon Wiman's talents. The Canadian-American once declared that Wiman was “...well qualified...to act as leader of the Canadian colony in New York." ${ }^{151}$ What is more fascinating than their interest though in the personal and professional life of Erastus Wiman was the paper's interest in the successes of other less noteworthy CanadianAmericans. The "Personal Section" of the paper would often contain detailed information on the successes of individual Canadians. A report on J.H. Detlor, formerly of Ontario, stated that he was "prospering in his new western home." The article went on to describe how Detlor “...purchased a fine farm in Wisconsin and is at present engaged as a foreman for the Pennsylvania Lumber Company..."152

W.H. Hastings, a young lawyer from Seaforth, ON, was reportedly on route to Grand Rapids, Michigan. The Canadian-American reported that Hastings was "a clever young lawyer and will no doubt make his mark in the larger sphere he has chosen." ${ }^{153}$ In the same issue announcements about the sucess in California of John Balkwill, originally of Exter, ON, and his prodigal return, as well as a new Minnesota based partnership between two Canadian born and trained doctors were also reported on. ${ }^{154}$ Two weeks later, the Canadian-American reported that a Mr. Bethune of Cornwall and brother to a well known Queen's Counsellor had been appointed the first State Geologist of Washington. ${ }^{155}$ In the section "About Canadians," A "Dr. Paton", "born and educated in

\footnotetext{
${ }^{150}$ One could note that both of Wiman's business callings - credit and telegraph - had clear continental implications.

${ }^{151}$ Ibid.

152 Ibid.

${ }^{153}$ Canadian-American, 11 April 1890, Vol. 8, Iss. 357.

154 Ibid.

${ }^{155}$ Canadian-American, 25 April 1890, Vol. 8, Iss. 359.
} 
Canada", despite in fact being of Bermudian birth, was a source of celebration for the paper as he was on the verge of being inaugurated as the President of Princeton University. ${ }^{156}$ Canadian success stories were not merely for their close friends and relatives back home, but were to be celebrated by the whole Canadian nation living in exile. As one Canadian-American wedding announcement put it "As there are many Canadians here and one is about to take the greatest step of his life [marriage]...all his friends out here wish him every success and no doubt his Chicago and eastern friends will also be pleased...". 157

The narrative of Canadian success, which at times included a story of a celebrated return to Canada, tended to emphasize pride in fellow Canadians among the million or so Canadians in the United States. It also had the effect of creating national heroes for a nation which existed beyond the boundaries of the Canadian state. Placing disparate stories beside one another on the pages of the newspaper tended to create the illusion for the readership that they were part of this singular though successful national community. ${ }^{158}$ At the same time, the continued maintenance of such a large national community beyond the jurisdiction of the Canadian nation-state served to undermine that state's authority to govern. While the Canadian state was able to maintain the integrity of its territory, it could not claim a congruency between that territory and the nation for which it was to be sacrosanct. As was mentioned in chapter one, Foucault has argued that the nation versus the state is one of the three major forms of counter-conduct in the modern period. Just as smuggling challenged the Canadian state's claims to effectively

\footnotetext{
${ }^{156}$ Canadian-American, 9 March 1888, Vol. 6, Iss. 259.

${ }^{157}$ The Canadian-American, 25 April 1890, Vol. 7, Iss. 359.

${ }^{158}$ For a discussion of the effects of print-capitalism on the making of national communities see Benedict Anderson, Imagined Communities, (London: Verso, 2006), 37-65.
} 
manage the population, emigration challenged its claims to manage the nation effectively. Rather, it is asserted the imagined community of Canadian-Americans, was by its very existence, a challenge to the authority of the Canadian state and its aspiration to convincingly separate American and Canadian socio-economic life.

What helped to undermine the authority of the Canadian state further was the Canadian-American's constant criticism and analysis of Canadian politics. By continually comparing American and Canadian policy, usually to the advantage of the former, the paper undermined the authority of the Canadian state to govern effectively. For example, in a racist attack on the Canadian policy towards indigenous peoples, the Canadian-American argued that it "...costs the Canadians too much to keep their Indians..." preferring instead the American policy of extermination. ${ }^{159}$ In the same issue the paper was happy to reveal the "unpleasant" truth that "...American national bank notes are the safest and hardiest money for Canadian travellers, even in their own country."160 Criticisms of the imperialist leaning of the Toronto Empire were common, with the Canadian-American advocating that it pay more attention "...to those [interests] that are strictly Canadian."161 In commercial relations, the inability of Canadians to achieve free exchange with their American counterparts was due to its position as a "beggarly dependent" of Great Britain. ${ }^{162}$

Yet, not all the commentary was negative. The paper often lamented the ignorance of Americans regarding Canada. On one occasion the paper criticized American papers for referring to Newfoundland as a Canadian province despite "...

\footnotetext{
${ }^{159}$ Canadian-American, 9 March 1888, Vol. 6, Iss. 259

${ }^{160}$ Ibid.

${ }^{161}$ The Canadian-American, 7 March 1890, Vol. 7, Iss. 352.

162 The Canadian-American, 21 March 1890, Vol. 7, Iss. 354.
} 
compulsory education..." in the United States. Often the paper attempted to synthesize what was best from both political experiments in North America. In an article comparing the Canadian and American constitutions the paper remarked that "...the articles of confederation...contain more desirable provisions than the constitution of any republic in the world...". 163

Comments like the last suggest that rather than promoting the United States as a model to emulate, the paper rather sought to use the examples of each country to critique the efficacy of governance in Canada.

While the frequent mention of the celebrated return home by Canadian-Americans suggests the porosity of the border, other statements were more explicit in their condemnation of the line between the two halves of the continent. In this vein, the Canadian-American loved to stress the similarities between Canadians and Americans and their ability to co-operate. In commenting on Canadian-American participation in politics in the North Dakota Legislature, the paper had this to say:

...despite the fact that in the Legislature of North Dakota there are twenty-two Canadians there is no CanadianAmerican party...Such a thing is unknown where the Canadian population is strongest... In politics our countrymen here are like Americans. ${ }^{164}$

As the above quote suggests, Canadian-Americans were portrayed as effective allies in combating faction in the political communities of the United States. In a handful of commentaries on Canadian history, connections between Canada and the United States were often stressed. One such example was the mention that Vermont almost joined

\footnotetext{
${ }^{163}$ The Canadian-American, 18 April 1890, Vol. 6, Iss. 358.

${ }^{164}$ The Canadian-American, 4 April 1890, Vol. 7, Iss. 356.
} 
Canada. ${ }^{165}$ In commentary written by an army Major from the American civil war, reprinted from the Boston Globe, the author praised Canadians as they "...made the best soldiers...physically..."166 Any conflict between Canada and the United States was deemed by the Canadian-American to be "...as bad as a civil war."167

Also, the paper tended to stress the irrelevance of the line. They often published sports results on cross-border lacrosse competitions. ${ }^{168}$ Similarly, the paper reported on how easy it was to simply "skip across the line" into Canada. ${ }^{169}$ The Canadian-American often referred to the border as an "imaginary line" in articles in order to highlight its insignificance. ${ }^{170}$ This was especially true for lacrosse and baseball clubs in the United States and Canada. Several lacrosse and baseball clubs were created by CanadianAmericans, such as the Maple Leaf Lacrosse Club of Philadelphia. ${ }^{171}$ Furthermore, these sporting teams participated in cross-border leagues, making the line less significant than the Macdonald government seemed to claim.

This line of argument further undermined the pretension indulged in by the Canadian state of nation-territory congruency. The effect was to undermine the Canadian state and its authority to delineate and maintain the boundaries of nation effectively. As one editorial put it: "Canadian colonies in the United States are so numerous that if the exodus goes on, Canada will be in the position of ancient Greece..."172

\footnotetext{
${ }^{165}$ The Canadian-American, 6 June 1890, Vol. 7, Iss. 365.

${ }^{166}$ The Canadian-American, 9 January 1891, Vol. 8, Iss. 396.

${ }^{167}$ The Canadian-American, 13 June 1890, Vol. 7, Iss. 366.

${ }^{168}$ Ibid.

${ }^{169}$ The Canadian-American, 9 March 1888, Vol. 6, Iss. 259.

${ }^{170}$ The Canadian-American, 13 June 1890, Vol. 7, Iss. 366.

171 The Canadian-American, 9 March 1888, Vol. 6, Iss. 259.

172 The Canadian-American, 27 February 1891, Vol. 8, Iss. 402.
} 
The effect of all this was to create a construct of nation which violated the juridical boundaries of the Canadian state. In doing so it was a direct challenge not just to the National Policy system, but to the entire state structure in Canada. This kind of withering critique was received not merely in the United States, but was also well known to the likes of Erastus Wiman and other continentalists who would come to dominate the intellectual content of that movement. As we shall come to see, the narrative of the experience of the ex-patriot community provided a potent theme within the intellectual discourse of continentalism that will be explored in chapter three.

However, before moving on to a discussion of the discourse of continentalism, it is necessary to understand not only how this community narrated its experience, but how it aimed to govern its existence as Canadians once it found itself south of the line.

Similarly, it is also necessary to understand the institutional structures it erected in order to encourage and reinforce the common social life of the community. As such, it is necessary to turn our attention to the major institution in the United States of Canadian cultural citizenship: the Canadian Club.

Canadian Clubs and Canadian-American Leagues could be found across the United States. From the pages of the Canadian American it is clear that by the 1890 s such organizations could be found in Detroit, Chicago, Cambridge, Massachusetts, Princeton, New Jersey, and most notably, New York. ${ }^{173}$ The official history of the Canadian Club of New York, the self-proclaimed original Canadian Club, reveals that it was initially founded at a meeting held at 3 North Washington Square, New York City on 30 April

${ }^{173}$ It is important to note that from the pages of the Canadian-American some groups of Canadians were active in the St. George's Society where they promoted a message of Anglo-Saxon unity. Unfortunately I did not have the time or space to offer an in-depth discussion of this less adamant group of CanadianAmericans. 
1885. ${ }^{174}$ The Club opened its doors on Dominion Day in the hopes of attracting the over 6000 Canadian residents of New York City as members. ${ }^{175}$ Though the first meeting was held at the Hotel Brunswick, the Club eventually found itself a permanent home at 12 East $29^{\text {th }}$ Street in "...one of the few ornate buildings in that part of New York." 176 Within two years of its founding, the Club had attained a membership of $400^{177}$ Canadian-born males "... of good moral character...". 178

As is clear from the above, the Canadian Club of New York was able to attract a significant membership of Canadian ex-patriots who still wished to define themselves as being "Canadian" in some way. It could be argued that gentlemen's clubs, like the one being discussed here, served networking functions in order to establish and reinforce business ties. Certainly this is one aspect of the club which saw its calling in part as one to "...guide and direct those who hereafter may join us in the pursuit of a career of usefulness...". ${ }^{179}$ Also, the club saw its role as promoting improved social relations among Canadians, “...to bring together those who would otherwise not come together." 180 As Benedict Anderson has argued, the construction of communities, particularly national ones, is intimately tied up with the growth of capitalism. ${ }^{181}$ So whether it was a calculated business manoeuvre or genuine amore patrie which brought individuals to the doors of the Canadian Club, what happened there was unmistakable. Inside the club house, the

\footnotetext{
${ }^{174}$ G.M. Fairchild, Canadian Leaves: History, Art, Science, Literature, Commerce. A series of papers read before the Canadian Club of New York, (New York: Napoleon Thompson \& Co., 1887), 284.

${ }^{175}$ Ibid.

${ }^{176}$ Ibid, 288.

${ }^{177}$ Ibid.

${ }^{178}$ Constitution and By-Laws of the Canadian Club of New York, (1885), 8.

${ }^{179}$ Fairchild, 285.

${ }^{180}$ Ibid., 286.

${ }^{181}$ Anderson, 37.
} 
members of the Canadian Club busied themselves constructing a nation along civic republican lines which denied the primacy of the Canadian state in defining the spatial boundaries of that nation.

The model of governance adopted by the Canadian Club of New York was firmly and significantly republican. The club's executive consisted of a president, five vice presidents, a treasurer and secretary. ${ }^{182}$ The executive was to have strict limits on their power in the fields of membership and affairs related to the management of the club house. The membership committee was made up of one representative from each province, not unlike a triple-E senate. ${ }^{183}$ The membership committee was free to act in secret to determine the acceptability of candidates for admission into the community of the Canadian Club. ${ }^{184}$ The committee acted as a kind of committee of elders to ensure congruency between the values of the community and the individuals who would enter it. This preoccupation with ensuring a base level of shared interest harkens back to civic republican concerns with interdependence and the maintenance of civic virtue.

The house committee, on the other hand, was to be made up of general members. It was required to meet twice a month to decide on matters such as pricing, purchases, the hiring or dismissal of employees and to redress complaints by the membership. It also had the power to suspend members from the club for misconduct with a $2 / 3$ vote. ${ }^{185}$ All persons holding such posts, from Erastus Wiman, the president, down to the members of the house committee had to be elected by the membership. ${ }^{186}$ In its separation of powers

${ }^{182}$ Constitution, 5.

${ }^{183}$ Ibid, 7.

${ }^{184}$ Ibid.

185 Ibid.

186 Ibid. 
and its tripartite structure, the Club functioned on a republican model of governance. The republican leanings went further, though, in the emphasis on morality and virtue as prerequisites for membership in the club. ${ }^{187}$ To this end, gambling was forbidden. ${ }^{188}$ Thus, the choice to govern through a republican system and to regulate inclusion and exclusion in the community along the lines of virtue all pointed to a civic republican concept of tight community being prevalent within the organizational culture.

Furthermore, as the volume Canadian Leaves attests, a common form of entertainment for the club was to invite speakers to present papers that the club could then discuss and debate. In short, deliberation was central to the conduct within the Club. As we shall see in chapter four, deliberation and republican notions of civic virtue became central to the political behaviours associated with the continentalism movement in Ontario. Furthermore, the implicit political activities undertaken at the Club created an affinity between continental migrants and the civic republican political tradition. By inviting speakers from across the line, the club also in a sense trivialized the border as a marker of Canadianess. With individuals such as Liberal leader Edward Blake, Prime Minister John A. Macdonald, former Liberal leader Alexander Mackenzie, and Ontario Liberal Premier Oliver Mowat forming a portion of the membership, it suggested that the state even recognized the validity of the claims of these émigrés as legitimate members of the Canadian national community in violation of its territorial integrity. Also significant, aside from the presidency of the continentalist Erastus Wiman, is the visits and membership of those who would become sympathetic to the continentalist cause, namely

\footnotetext{
${ }^{187}$ Ibid, 8 .

${ }^{188}$ Ibid, 9 .
} 
Goldwin Smith.

In short, the Canadian Club of New York and similar organizations across the line enjoyed access to and recognition by the Canadian state elite and a flourishing civic republican community culture. This elite-sanctioned culture served to undermine the expanded claims of authority and legitimacy made by the Canadian state to define the boundaries of nation on associational terms through the new instrument of the National Policy. As such, two definitions of Canadian nation can be said to have existed. One was already fully articulated, which envisioned the nation ending at the customs house, and another, beginning to be articulated, saw the boundaries of community defined by shared practices, civic participation and virtue. It was these two definitions of national community, liberal and civic republican, which came to shape the content and trajectory of the continentalist movement in the late-1880s and early $1890 \mathrm{~s}$.

\section{Coding the Behaviour}

Smuggling and emigration represented the first and most obvious signs of resistance to the emerging Macdonaldian political-economic system. Smuggling represented a major challenge to the claims of the state, articulated and enforced through the National Policy, to the right to define the economy - or the realm of legitimate material relationships one could have as a member of the Canadian population. Similarly, emigration served to challenge the ability of the state to fulfill its mandate to protect and maintain the integrity of the Canadian nation against threats to its survival. 
While the above documentation of the responses of the Ontario population to the new political-economic demands of the National Policy provides some insight into the gestation of the continentalist agitation, it is not the sole cause of the development of a politically self-aware continentalist movement. What is present a set of shared strategies for circumventing the National Policy. While these strategies provide a basis for a shared experience they do not of themselves provide a complete narrative of that experience necessary for the expression of the positive political claims made by continentalism from 1886-1893. Rather, actions of smuggling and of emigration are only smuggling and emigration, no more and no less, until they are framed otherwise. In the Liberal press, as was demonstrated above, smuggling became framed as a conduct of resistance to the National Policy. Similarly, the Canadian-American, by reporting on and narrating the conduct and experience of the one million Canadian immigrants in the United States, was instrumental in articulating a notion of national community which defied the categorization of the Canadian state and questioned its very authority and ability to provide for the maintenance of the Canadian nation.

Central to the coding of behaviour is discourse, and a fully articulated discourse of continentalist counter-conduct had not taken definite shape until the mid-1880s. Without a discourse, that is a common narrative that gives the acts of smuggling and emigration a definitive political objective other than resistance, there is no way for individuals to imagine themselves as part of political movement aiming at achieving a particular political end. 
As such, it is necessary to turn to the increasingly intense development of the discourse of continentalism between 1878 and 1893 in the next chapter in the hopes that its exploration will help to elucidate the relationship between the formal counter-conduct of continentalism and the everyday acts of resistance to the National Policy. 


\section{Chapter 3: The Language of Continentalism}

While the National Policy was the unexpected catalyst for the emergence of unorganized practices of resistance that were continentalist in orientation, continentalism was no narrow reaction to a specific government policy. Rather, these unorganized practices were soon recast as a part of a more sophisticated and self-confident movement for a continental policy. It was thinkers such as Erastus Wiman, Goldwin Smith, Edward Farrer, Thomas Shaw and Vallancey Fuller, among others - who, through the development and dissemination of their ideas, remade what was a disorganized borderland resistance into a formal political opposition to the National Policy and the Macdonaldian order.

The first hint at the possible depth and breadth of this discourse can be found in an essay on Canada which appeared in the British periodical The Fortnightly Review on the eve of the 1878 election. Goldwin Smith, the Toronto-based gadfly of the later half of the nineteenth century, published his appraisal of the first decade of Canadian confederation. In his elegant prose, Smith argued that Confederation had been a failure. Canadians had failed to embrace their new nationality or even develop a patriotic sensibility. ${ }^{189}$ Furthermore, the political corruption, jostling for "better terms" amongst the provinces and the failure to renegotiate a reciprocity agreement with the U.S. in 1874 all indicated as far as Smith was concerned - that Canada would soon disintegrate, first economically and then politically into the United States. ${ }^{190}$ As Smith would later remark in commenting

${ }^{189}$ Goldwin Smith, The Political Destiny of Canada [microform], (Toronto: Willing and Williamson; London: Chapman \& Hall 1878), 16.

${ }^{190}$ Ibid., 16-18. 
on his own essay, the entry of the Canadian provinces as a part of the United States was certain as even “...nature puts her vote upon [it]." ${ }^{\text {9191 }}$ Smith, a professor at both Cornell and Oxford and a well known transatlantic man of letters, republished his essay in 1878 after the Macdonald election victory in the National Policy election of 1878.

Ironically, Smith shared the prime minister's initial argument that the so-called National Policy tariff was merely a temporary recourse to protectionism. While it erected a tariff, counterbalancing the tariff erected by Americans, it also included a clause for the automatic removal of duties when the Americans allowed any Canadian good across the border duty free. ${ }^{192}$ Both initially saw the tariff as a dynamic policy designed to force open the American market, not to isolate Canada from the rest of the continent. As Smith and other continentalists saw it, there was nothing to object to this pry-bar policy as it was initially conceived. Reciprocity of tariffs in the eventual hope of reciprocity of trade made sense. Yet, as the Liberal press and everyday Canadians increasingly resisted the tariff regime through smuggling and emigration to the United States, Smith and other continentalist thinkers would gradually make common cause with the smugglers and other groups in Canadian society against the tariff and the very shape of post-Confederation governance in Canada. ${ }^{193}$ By 1879 , as Macdonald and Tilley emphasized that the National Policy was a "permanent" policy, not simply a ruse to force Americans to the negotiating table, Smith and others began to look askance at the tariff wall and its isolating effect on the young country.

${ }^{191}$ Goldwin Smith to G.W. Curtis, 10August 1879, [Letter], Goldwin Smith Fonds, Library and Archives Canada, Ottawa, ON.

${ }^{192}$ Pennanen, Gary. "Goldwin Smith, Wharton Barker and Erastus Wiman: Architects of Commercial Union."Journal of Canadian Studies 1979 14(3), 50.

193 Ibid., 50. 
While Macdonald's government busied itself in Ottawa constructing the technocratic skeleton of an isolated Canada from sea to sea, Goldwin Smith busied himself in Toronto establishing a journal called The Bystander in order to promote commercial union as an alternative to the protectionist system of the National Policy. ${ }^{194}$ In 1881, the Annexation Manifesto of 1849 was reprinted with the corresponding signatories, some of whom were now leading elder statesmen of the Conservative cabinet. ${ }^{195}$ Here was evidence of the hypocrisy of the Ottawa protectionists.

With the persistent depression in the 1880 s, continued unrest in the North-West and the intensification of linguistic, religious and regional conflict, the individuals within the young Dominion were inclined to entertain alternatives to Macdonald's fortress-like vision of Canada was easily aroused. Consequently, interest in the possibilities of a continental solution to the economic and political woes of life in Canada was on the rise. Commercial union and political union both became viable options in Ontario politics. Smith was no longer alone and found himself joined by groups from varied classes on both sides of the border. ${ }^{196}$

Though continentalist thought began maturing under Smith's leadership in the late 1870 s, it was in the late 1880 s and early 1890 s that it began to reach its most articulate and inventive phase. By the late 1880 s, continentalism had rooted itself among certain groups. The smugglers took a back seat in a movement now driven by Commercial Union Clubs and Farmer's Institutes and Clubs across Ontario. Unveiled in 1888, the new Liberal Party policy of "unrestricted reciprocity" - a term coined by the

\footnotetext{
194 Ibid, 52.

${ }^{195}$ Annexation Association of Montreal. The annexation manifesto of 1849 [microform] :reprinted from the original pamphlet, with the names of the signers. (Montreal? : s.n., 1881), 1.

196 Ibid.
} 
continentalist and annexationist editor of The Daily Mail and later The Globe, Edward Farrer - was simply "commercial union" by another name. New spokesmen emerged for the movement. The main spokesmen of the group included the financier Erastus Wiman, politicians like Richard Cartwright and John Charlton, and farmers like Vallancey Fuller and Thomas Shaw. Others would subsequently join the refrain for a continental economic, or political policy. Hard times had increased the allure of alternative visions of Canadian political destiny.

Continentalist sentiments may not ever have captured majority opinion, but the economic and political union wings of the movement both enjoyed strong and often overlapping support until 1893. Understanding the appeal of continentalism is no simple task. Certainly, as Christopher Pennington has pointed out, its popularity was in part the result of a desire to ameliorate Canadian-American relations. ${ }^{197}$ However, it was never simply an economic or political nostrum, nor was it an outright rejection of the governmentalization of the state; it was a way of looking at, and indeed, of critiquing, the effectiveness of the tactics being employed by Macdonald and the Conservatives for securing the ultimate objective of the governmentalization of the Canadian state. Support for the movement was driven not only by concerns for material security, but also by deeply-held concerns about the ability of the Conservatives to construct an effective governmental order through protection in Canada and Ontario. Continentalism, along with raising some important questions, offered some creative answers to the question begged by the events of 1867: What was the Dominion of Canada? While the term "Dominion" may have meant something specific to the middle-aged, white men who

${ }^{197}$ Pennington, 65. 
drafted the British North America Act and who subsequently sat in the legislatures of the confederation, it is likely that its meaning was far more contentious outside the realm of high politics. For the vast majority of Canadians its meaning was nebulous and could have indicated a loose aggregation of colonies or a more centralized colonial or national legislature in some lumber town named after a military engineer. Continentalism emerged as an assertive political movement logically and legitimately out of this striving for a more precise definition of The Dominion of Canada.

Along with engaging in the question of what Canada was and what its future was to hold, continentalists were also remarkably consistent and well organized in their approach to disseminating their message. It is evident from an analysis of the content of sources as diverse as the Liberal press, farm journals, pamphlets and Canadian ex-patriot newspapers, ${ }^{198}$ that the message of continentalism was repeated frequently and consistently for a wide audience of readers and thinkers. Historian Ben Foster has argued that the protectionist inclinations of Canada's would-be manufacturing class were stamped all over the National Policy. ${ }^{199}$ This research suggests that continentalist opinion had clear and organized support from other groups in Canadian society.

What will become clear after a detailed analysis of the discourse of continentalism and its dissemination is that continentalism often filled the role of providing a viable alternative to the organization of governance under the Macdonaldian system, of which

\footnotetext{
${ }^{198}$ Hansard also contains some brilliant examples of the continentalist discourse. However, aside from those political speeches that were published, many of them would not have been available except for the handful of politicians present at its exposition. As such, a discussion of the stuff of high politics, of which these speeches constitute one portion, will be left for the end of chapter four which deals with the relationship between the Liberal Party and the continentalist movement.

${ }^{199}$ See John Jakub Benjamin Forster, Tariffs and Politics: The Genesis of the National Policy, 1842-1879, (PhD Thesis: University of Toronto, 1982).
} 
the National Policy represented the chief instrument. Continentalists not only offered new ways of seeing and "imagining" Canada economically, politically and socially, but offered sometimes valid and insightful criticisms about the strategies and tactics employed by the Canadian state. As has been previously argued, the National Policy tariff was the central institution for the creation of a sense of social cohesion between the disparate populations of the new Dominion. As Bruce Curtis has argued, the census made the Canadian population, and thereby rendered it governable. ${ }^{200}$ When the united colony of Canada East and Canada West expanded in 1867 with Confederation, the population generated by the Canada census of the 1850 s and early 1860 s was no longer valid. Rather, the Canadian population as an object of expert knowledge came up against other similarly defined populations in the Maritimes and elsewhere. The multiple populations that Confederation was forced to contend with needed to understand their membership in a national population as superior to their membership in their provincial population. One strategy for securing this end was the National Policy as discussed in chapter two. Establishing economic interdependence and generating congruency between territory and nation was a seemingly viable way to educate and convince members of Canadian society about the validity of the new social imaginary of the Canadian state. Yet, as we have already seen in chapter two, resistance to this project was almost immediate and was sanctified by certain parts of the Liberal press.

What began as a simple unorganized counter-conduct to the new protectionist measures of the state was effectively remade into a sophisticated, discursively anchored counter-conduct rooted in the civic republican political tradition. This discourse of

\footnotetext{
${ }^{200}$ Curtis, 24.
} 
continentalism did not deny the need for the governance of the population, nation or civil society, but rather posited a different objective that required different strategies and tactics rooted in the use of the market and a shared ethnic-racial heritage between North Americans for inculcating the body politic with civic republican values. The language of civic republicanism - of faction, civic virtue and community - became the language of continentalism and as such the political tradition from which continentalism was narrated as a counter-conduct. These were values that echoed from early nineteenth century Ontario. They drew their legitimacy from the Jeffersonian and Jacksonian-inspired Upper Canadian politics, politics that had opposed the early Tory oligarchy. ${ }^{201}$ Furthermore, as continentalism became more robust, its attacks on the governmental order came to focus on criticisms concerning the management of the population, the nation and of civil society. The three types of counter-conduct - by the population against the state, by civil society against the state, and by the nation against the state - became couched in civic republican values long familiar to the agricultural interests in Ontario. ${ }^{202}$ By fusing the initial counter-conducts of smuggling and emigration with the explicit language of the civic republican tradition, continentalism was rendered politically intelligible within the context of Ontario political culture. This led to its ascendance as a viable governmental alternative. Exploring each of these three categories of counter-conduct as they appear in the discourse of continentalism will help to explain the second phase of the evolution of the continentalist movement as it moved from an unorganized resistance led by the merchant class and the diverse Canadian diaspora in the early $1880 \mathrm{~s}$, to one that was

\footnotetext{
${ }^{201}$ Janet Azjenstat \& Peter J. Smith, "Liberal-Republicanism: The Revisionist Picture of Canada's Founding" in Janet Azjenstat \& Peter J. Smith (ed.) Canada's Origin: Liberal, Tory, or Republican?, (Ottawa: Carleton University Press, 1995), 1.

${ }^{202}$ See Foucault, Security Territory Population, 357.
} 
politically organized and dominated by agrarian interests in the province of Ontario by the late $1880 \mathrm{~s}$.

In exploring these questions, there is a rich and overwhelming body of continentalist literature to draw from. Rather than casting the net too widely and seeking out every shred of continentalist literature, the approach here will be to focus on works which were not only articulate and sophisticated, but also widely circulated and used in disseminating the gospel of continentalism. With this in mind, our attention will be directed primarily towards the work of Goldwin Smith, the speeches of Erastus Wiman and the collection of speeches published by the Commercial Union Club in The Handbook of Commercial Union. Published in 1887, The Handbook was not merely a piece of published material for politicians and elites, but was intended as a concise and comprehensive statement of the objectives of continentalism and as a tool for the promotion of continentalism. With this last end in mind, speeches were included from many of the important continentalist speakers already mentioned and targeted at a variety of audiences including farmers, labourers, and manufacturers to name but a few. Consequently, The Handbook represents the most comprehensive and strategic collection of continentalist thought available.

Since our interest is not merely in what continentalists said but how that message was disseminated and - as we shall see in chapter four - received, much of the analysis of this chapter is focused on the content of The Handbook and other popular incarnations of continentalist discourse. 
Bio-power and the Market: The Population against the State

In using the term population it is essential to provide a clear definition. This thesis adopts the Foucauldian definition of population, specifically as it is developed in the Canadian context by Bruce Curtis. In Curtis' The Politics of Population the population is explained as;

...a theoretical, not an empirical entity. Population is not an observable object, but a way of organizing social observations. The concept emerges out of projects that seek to configure social relations so that they may be known and mastered...[and so that social life may be invested] in governmental and administrative forms. ${ }^{203}$

The purpose of organizing and administering these social relations is to fulfil what Foucault identifies as the major state function in the modern era: the governance of life and death, or bio-power. Bio-power, Foucault has argued, is central to the way that the modern state governs. In Security, Territory, Population, Foucault makes the case that by the nineteenth century bio-power - the governance of the biological functions of the population: of life and death, of reproduction, of health and illness - had become the chief focus of state action, overshadowing concerns with territorial sovereignty. ${ }^{204}$ A central part and precondition of this governance is ensuring the material subsistence of the population. As such, debates about economics are ultimately debates about the proper governance of the population in two fundamental ways. They are debates about the proper social relationships members of any constituted population may have on a daily basis through the exchange of goods and services as well as debates about how to best ensure the legitimacy and establish the authority of the state by ensuring control over the

\footnotetext{
${ }^{203}$ Curtis, 24.

${ }^{204}$ Foucault, Security, Territory, Population, 1
} 
processes of life in general and material subsistence in particular. Material subsistence is connected to Foucault's concept of biopolitics in an important way. While biopolitics is defined as the maintenance over birth, death, marriage and other organic functions, material security is central as a precondition and strategy for ensuring the proper maintenance of the biological functions of the constituted population. What makes the "economy" different as a social imaginary from "population" is that, while population is a strategy for creating and inserting the state in the social relations of a "free" society, the economy is a tactic aimed at regulating those social and subsistence relations on a daily basis, thereby providing the state with legitimacy in the particular field of the biopolitical. Thus, it is the specific way that those involved in the governmentalization of the state, chose to legitimize the modern art of government and enhance the new political rationalities grip on the various members of the expert-constructed population.

This lengthy discussion is relevant for the purposes of this thesis because continentalists frequently deployed language which spoke of the security and well-being of the population. The allegations against the National Policy and the system of governance promoted by the Liberal-Conservatives centred, in part, around criticisms of their ability to manage and provide for the security and maintenance of the population effectively. Claims like those of the continentalists discussed below, of the population against the state, were not disavowals of governance of the population as a political objective, but rather critiques of the efficacy of the tactics and strategies being deployed by the state, tactics and strategies like the National Policy. These claims of the population 
against the state manifested themselves in several discursive forms within continentalist thought.

First, continentalists emphasized that theirs was not a political question, but rather one focused on purely economic matters. ${ }^{205}$ That is, they focused on the material health and well-being of the population. As Wiman put it, political union was a question for another time. ${ }^{206}$ T.D. Ledyard, a mine owner and operator, put it more subtly when he said "our commercial interests are identical, and the fact of our having different political arrangements should not make trade between us less profitable."207 Thomas Shaw, the secretary of the Ontario Farmer's Institute, editor of The Livestock and Farm Journal, and later a professor at the Guelph Agricultural College, framed it as a question about "consumer rights." "208

By emphasizing the supremacy of the economic sphere over the political, the continentalists were denying the efficacy of the Macdonaldian system, of which the National Policy was the chief instrument, to ensure the material security of the population. While Macdonald's National Policy sought to make the economy and population visible and subject to the power of the state, continentalism by denying the "political" nature of the question, was attempting to de-centre the National Policy and the state in the process of governing the population, favouring instead the free market as the chief tactic of

\footnotetext{
${ }^{205}$ Goldwin Smith, Speech of Mr. Goldwin Smith, at the banquet of the Chamber of Commerce of the State of New-York [microform] : November 20, 1888. New York : Press of the Chamber of Commerce, 1888, 7. ${ }^{206}$ Erastus Wiman, The Capture of Canada, (New York: s.n., 1890), 10.

${ }^{207}$ G. Mercer Adam (ed.), Handbook for Commercial Union: a collection of papers read before the Commercial Union Club, Toronto : with speeches, letters and other documents in favour of unrestricted reciprocity with the United States, (Toronto: Hunter Rose, 1888), 84.

${ }^{208}$ Ibid., 72.
} 
governance. ${ }^{209}$ Therefore, continentalism was not an anti-national prescription. Rather, continentalism questioned the efficacy of the explicit imposition of the state in the economic imaginary. Continentalists preferred an approach which stressed the market as the most effective strategy for ensuring social harmony and the maintenance of the population's biological functions.

By placing the economy first, continentalists were not just pursuing a narrow policy of self-interest or stating that they were only interested in the economy. Rather, this was a coterie of people who read and understood economics as "political economy". As such, they understood that the free market economy was not only a mode of exchange but also a way of governing the material and moral existence of the population. The "invisible hand" became a metaphor for the proper governance of the population. Wiman even uses the image of the hand to describe the North American continent. The palm is the United States, while the fingers are the regions of Canada from the maritimes, as represented by the little finger, over to British Columbia represented by the thumb. The tariff wall becomes the barrier at the base of the fingers restricting the proper operation of the economic "hand". ${ }^{210}$ Protection then restricted and disrupted the natural social circulation that the market created. It was a tactical criticism, not one of overall strategy or objective.

This image of the hand given to us by Wiman is but one example of the way in which the economy was imagined as impeded by the explicit projection of the Canadian

\footnotetext{
${ }^{209}$ See Mitchell Dean, Governmentality: Power and Rule in Modern Society, (London: Sage, 1999), 114115. For a discussion of the process of governmentalization of the state as it relates to the economic sphere. ${ }^{210}$ Erastus Wiman, Closest trade relations between the United States and Canada [microform]. (Toronto: National Pub. Co., 1892), 10.
} 
state into matters of social relations. It also suggested that the hand's natural and long existing predisposition was to unimpeded action, action that was interrupted by the state. Claims about the improper functioning of the economy served as metaphors that emphasized the ineffectiveness of the National Policy as an apparatus of security. The continentalist imagery tended to suggest to Canadians that the hand that fed them was being mangled by an unnatural constraint: the National Policy.

Critiques which centred on the inability of the Macdonaldian system to provide for the security and well being of the population were also rooted in discussions about Canada's potential and actual wealth. Echoing this theme were declarations such as those made by Wiman that Canada was "the greater half of the continent". ${ }^{211}$ By this, Wiman meant that Canada was a "treasure house" for the continent full of potential to grow and prosper; a place where it was possible to sustain and provide for the material security of a population. $^{212}$ T.D. Ledyard felt that the Canadian market did not count for much, but what did count was Canadian ore and its convenient location near the American manufacturing centres. ${ }^{213}$ Ledyard reasoned that if American capital could only be brought to develop the mines, Canada's destiny could be achieved. W.H. Lockhart Gordon, a British politician, echoed this sentiment, arguing that Canada was rich in natural resources and had been retarded from its potential by current commercial policy. ${ }^{214}$ For Thomas Shaw, nature not only intended trade to run North-South, but the American

${ }^{211}$ Erastus Wiman, Canada and Great Britain [microform] : report of Erastus Wiman on the Congress of the Chambers of Commerce of the British Empire, held in London, June, 1892. (S.1.: s.n., 1892), 5.

${ }^{212}$ Erastus Wiman, Union between the United States and Canada [microform] : political or commercial : which is desireable and which is presently possible? (New York: s.n., 1891), 7.

${ }^{213}$ Adam, Handbook of Commercial Union, 75.

${ }^{214}$ Ibid., 101. 
market was the nearest and as such must be the cheapest and best market. ${ }^{215}$ For John Charlton, a Liberal MP and lumber baron, "it would be half a century before our market would be in a condition like that of the American market at the present moment."216 Goldwin Smith put it best in Canada and the Canadian Question when he said "Canada is rich by nature and poor by policy." ${ }^{917}$ By concentrating on the absence of a Canadian market free from explicit state involvement, and the Canadian economy as underdeveloped, the continentalists were critiquing the ability of the Dominion government to provide for and ensure the material security of the population: to fulfill their biopolitical mandate. It was, therefore, the inability of the Macdonaldian system to provide material security to the population that was at issue, and which stemmed from, according to continentalists, a disregard for the market economy as a tactic of governance. ${ }^{218}$ By focusing on the management of the population by invoking the economic dimensions of the question as well as the failure of the Canadian market to provide security independently of other markets, it undermined the claims of the Macdonaldian system of effective management of the population and also recast Canada as an entity whose juridical boundaries did not coincide with the socio-economic boundaries necessary to sustain the population.

Continentalists often used statistics effectively to undermine the National Policy and press the claims against the tactics employed by the state to manage the population. That statistics codified social relations, including economic ones, is true, but by reconfiguring raw data, the meaning and consequently the power relationship within these

\footnotetext{
${ }^{215}$ Ibid., 55-56.

${ }^{216}$ John Charlton, Speeches and addresses: political, literary and religious. Toronto: Morang, 1905, 123.

${ }^{217}$ Goldwin Smith, Canada and the Canadian Question, 278-279.

${ }^{218}$ Dean, 105.
} 
codified interactions could be reorganized. This tactic was commonly employed by continentalists. Their writing included detailed analyses of statistics on population, emigration to the United States from Canada, immigration to Canada, trade with the United States and Great Britain. Such uses, while reinforcing the Canadian state's exercise of bio-power on the population in the general sense, in fact undermined the particular tactics employed by Macdonald and the Conservatives. Continentalists used statistics to identify the missing population: the million or so Canadians who had crossed the border to make new homes for themselves in the United States. Those members of the missing population, in their exodus, had moved beyond the jurisdiction of the Canadian state. However, the continentalists were acutely aware that these individuals often participated in the social life of the Dominion, bringing into question the utility of a national census as an effective imaginary for social relations. Instead, the possibility of their continued inclusion as part of the social imaginary of Canadian life could be brought about by an unfettered market economy. The continentalist prescription for free trade or political union undermined the Conservative approach to regulating and normalizing the population. Using the state's own tools against it, statistics were used to predict the effects of commercial union. Furthermore, the continentalists considered such statistical information to be "accurate."219 Thomas Shaw used statistics to suggest that greater opportunities for farmers would lie with continental union. ${ }^{220}$ James Pearson of the Almont Gazette stressed that economic questions must be treated in "...a calm and deliberate manner, relying upon cold facts to bear us in our contentions."221 The editor of

\footnotetext{
${ }^{219}$ Adam, 3.

${ }^{220}$ Ibid., 65.

${ }^{221}$ Ibid., 122.
} 
The Daily Mail, Edward Farrer, felt that statistics were essential to his editorials which advocated for commercial union and even annexation. ${ }^{222}$ Statistics, according to continentalists, seemed to indicate that official trade was equal with Great Britain and U.S. ${ }^{223}$ The continentalists saw this as evidence that the "natural" market for Canada was the United States, and therefore, the natural socio-economic boundary was continental. Statistics, in the mind of the continentalist opposition did not deny the bio-political objectives of the state, but rather attacked the particular strategy of protection for achieving that end.

As such, it is clear that in using statistics and invoking the unfettered market as an alternative tactic for governing the population, the continentalists were not directly opposing the governmentalization of the state, but rather promoting an alternative strategy for managing the population. Their approach relied more on the implicit rather than explicit involvement of the state in social life through the imaginary of the free market economy. The alternative strategy of free trade was drawn in part from the free market liberalism of Smithian bent, but also, and more significantly, from civic republican sources that imagined the community as free from arbitrary political authority. As such, continentalists viewed the actual material relations of the population generated under the free market as superseding state-based attempts at establishing the community through imposed socio-economic interdependence, and instead stressed the interdependence generated by a free market system. Thus, their vision of Canadian society was no less

${ }^{222}$ Ibid., 278

${ }^{223}$ Ibid., 272. 
patriotic and no less interested in the proper functioning of the Canadian state than Macdonald's.

Faction, Corruption and Degeneration: Civil Society against the State

While the opposition of the population to the state was central to many of the critiques developed by the continentalists against the Macdonaldian system, the other forms of counter-conduct were instrumental in establishing explicitly not just what continentalism opposed, but also what it stood for. The case of the opposition of civilsociety against the state must be understood - much as with the case of the population discussed above - not as a critique of the governance of the public sphere and citizenship per se, but rather as a critique of the efficacy of the tactics deployed by the state to that end. Thus, continentalists were concerned with the effect of the Macdonaldian system on political morality and, by extension, the ability of citizens to govern themselves properly and thereby to participate fully in the political community. It is perhaps prescient to remind ourselves that in the civic republican tradition, participation in the political community was the highest expression of freedom, yet this freedom required a commitment to govern oneself correctly so as to be able to participate fully in the freedom granted by civic participation. It is in this kind of thinking that echoes of Jeffersonian and Jacksonian themes as well as the Clear Grit movement in Ontario are easily heard. As such, this variant of counter-conduct is where the civic republican values are most strongly articulated. Terms like "faction", "corruption" and "dependence" are contrasted with "community," "virtue," and "independence" in order to highlight the presence of 
disorder and the absence of order within civil society as a result of the Macdonaldian system.

Attacks on the tariff often reflected concerns about dependency and corruption within the political community. Farrer captures the idea of the tariff as an impediment to independence and political virtue when he called it "... an engine of far reaching oppression." ${ }^{224}$ Cartwright later claimed, in his forceful Reminiscences, that the National Policy was a perversion of the British North American Act. ${ }^{225}$ In Canada, the rule was "government by organized corruption" and "bribery."226 Invoking the language of imperial racism and the implied hierarchy associated with it, Cartwright determined that even with all the bribery they could not "wash the political Ethiopians [of Macdonald's party] white."227 The association of corruption with the National Policy and the Macdonaldian system was used to show the degradation of virtue that particular order was visiting upon the political community.

Complaints against the politicized economy of the National Policy were not limited to allegations of corruption. Goldwin Smith echoed the republican themes of faction when he stated that the tariff, a product of the federal government, reflected narrow class interests rather than the national interest. ${ }^{228}$ This demonstrates the attempt by continentalists to derogate the Macdonaldian system on the grounds that it created faction within society. This "class" that the continentalists felt was being privileged

\footnotetext{
${ }^{224}$ Ibid., 292.

${ }^{225}$ Sir Richard Cartwright, Speech of Sir Richard Cartwright at Ingersoll, Now. 14th, 1889. (S.1.: s.n., 1889), 17.

${ }^{226}$ Ibid., 5.

${ }^{227}$ Sir Richard Cartwright, Canada go bragh [microform] : being an inaugural address to the Young Liberal Club, of Seaforth, Ont., on the 27th October, 1886. (Toronto: Hunter Rose, 1886.), 31.

${ }^{228}$ Adam, 195
} 
above all others, were the "artificial" manufacturers who were friends of Macdonald's Liberal-Conservative Party. Manufacturers were seen as a small selfish group who lacked "vigour" - a Darwinian term implying in part the inability to survive independently - as a result of living under the protective system. This special treatment violated the civic republican rationale of equality and, as such, acted as a source of faction within the community. ${ }^{229}$ W.H. Lockhart Gordon reasoned that "anything threatening the manufacturers" would be deemed disloyal by Macdonald's government. The great fear, in continentalist minds, was the tendency of the tariff to produce monopolies which, as Thomas Shaw reminded his contemporaries, was not a question of the size of the business, but a question of “... ethical degeneracy in business" resulting in harm to consumers. ${ }^{230}$ As such, the tariff had not just interrupted the natural development of Canada, but it degraded the moral development of the Canadian state, and visited the evil of faction and special interest upon Canadian civil society.

Continentalists tended to place this narrow class of manufacturers, and their middle men and legal counsels, in an antagonistic relationship with the rights and interests of "19/20ths of the whole population." "231 These other classes were divided not into middle, upper, and lower categories, but rather by industry, that is by their role within the economic community. Whether owner or worker, one's class identity was based on the economic sector one belonged to. For continentalists, the most important of these were the fishermen, farmers, lumbermen, miners, railroad owners, and the producing classes, or natural manufacturers. ${ }^{232}$ The emphasis was upon understanding each as a participating

\footnotetext{
${ }^{229}$ Ibid., 96.

${ }^{230}$ Ibid., 62.

${ }^{231}$ Ibid., 26.

${ }^{232}$ Ibid.
} 
with an identifiable role to play within the interdependent community generated by the market economy. The continentalists organic definition of class within society harkened back to the producerism of H.H. Carrey and Isaac Buchanan, without the corresponding protectionist prescription. The emphasis on productive labour as the cornerstone of community can be traced back to the early republican economics of Quesnay's Tableau which saw agricultural labour and production as the foundation of all other wealth. Furthermore, in keeping with civic republican values, the extension of privilege to one class along with promoting faction also deprived those minorities of the privilege of being considered a legitimate part of "the people" or the political community. As such, Macdonald and his supporters lacked political authority due to the tendency of their policies to undermine political virtue.

As the quotations above suggest, several of the articles in the Handbook of Commercial Union are directed specifically at the "corrupt manufacturers", as defined by the continentalists. Several tracts encourage the majority of Canadians to oppose the special interests of manufacturers. Civic republicanism envisioned the need for equality of virtue and procedure among members of any political community in order to insulate that community from faction and corruption. It offered an organic model of society in place of the technocratic one then being constructed by the Conservatives.

Continentalism was heralded as the best economic policy to ensure material well being for farmers, natural manufacturers and even factory workers and artisans. In the latter case, this improvement can thankfully be achieved without resorting to unionization to achieve higher wages; another source of faction and dependence in the community according to 
continentalists. ${ }^{233}$ In civic republican thought, independence and equality are preconditions for political participation and, consequently, freedom rather than the product of limited government as is the case in liberalism.

Arguments that the independence of members of the Canadian society, defined in Jeffersonian terms as the freedom from being bought off and materially subjugated, had been compromised also came in the form of arguments about social control.

Continentalists argued that manufacturers and the Liberal-Conservative Party exercised a kind of social control over the other classes in society through the use of media and language. Lockhart Gordon argued that one tactic was that the manufacturers and the government declared anything that opposed the National Policy as disloyal:

I imagine I already see the man with the loyalist fad pointing his finger of scorn at me...not because of his extreme attachment to good old England, but because he thinks his petted and pampered industry is in danger, and in his utter dearth of argument he resorts to ridicule..$^{234}$

Smith delivered three lectures to the Young Liberals in order to stir up their passions for the ensuing election campaign in the first months of 1891. In two of the lectures, Goldwin Smith spoke about loyalty and jingoism. Smith called loyalty a "mask for corruption." ${ }^{235}$ For Smith, those who professed loyalty to the crown often acted in a disloyal manner towards the "commonwealth" and Canada. ${ }^{236}$ And finally, pointing his finger directly at Macdonald, Smith declared that all corruption and sectionalism was disloyalty. ${ }^{237}$ It was not only the language of Canada's incumbent politicians that the

\footnotetext{
233 Ibid., 142.

${ }^{234}$ Ibid., 99.

${ }^{235}$ Goldwin Smith, Loyalty, Aristocracy and Jingoism: three lectures delivered before the Young Men's Liberal Club Toronto, (Toronto: Hunter Rose, 1891), 6.

${ }^{236}$ Ibid., 11-12.

${ }^{237}$ Ibid., 15-16.
} 
continentalists attacked. In jingoism, Smith also claimed that the school system was being used to teach hatred of Americans to children. ${ }^{238}$ Smith went even further: "The real sentiment of the people is greatly hidden beneath the conventional sentiment which the official class labours with every engine of moral coercion to maintain." 239 Richard Cartwright even accused Macdonald of bribing the newspapers. ${ }^{240}$ For Smith and the continentalists, it was the whole state, institutions, elite classes and newspapers that were engaged in controlling the mass of society; denying society its independence and corrupting the political community. Evident here is not only a resistance to the Macdonald's particular strategies and tactics for the governmentalization of the Canadian, but also a concerted attempt to reorganize this process around a civic republican moral order where the moral economy of the market would take the leading role in the governmentalized state rather than a disciplinary protective tariff.

The continentalists also prescribed "manly" values for Canadian society. This gendered discourse stemmed from continentalist concerns about the lack of independence of Canadian citizens, and thereby their suitability for participation in a political community. ${ }^{241}$ Several of the continentalist thinkers also entertained anti-feminist beliefs. Smith, for example, opposed granting equal rights to women. ${ }^{242}$ During this period, republicans on both sides of the border were particularly concerned with "overcivilization" amongst the white male population. In many cases, la doue commerce was

\footnotetext{
238 Ibid., 24.

${ }^{239}$ Goldwin Smith. Political relations of Canada to Great Britain and the United States: an address delivered to the Nineteenth Century Club, New York, on the 31st January, 1890. (Toronto: Hunter Rose, 1890), 20.

${ }^{240}$ Cartwright, Speech at Ingersoll, 12.

${ }^{241}$ Cartwright, Speech at Ingersoll, 26

${ }^{242}$ Goldwin Smith, Women's Place in the State [microform], (S.1: s.n., 1890), 526-527.
} 
thought to be one of the main causes of men's emasculation. ${ }^{243}$ Returning to nature or the performance of physical labour was often seen as a way to reconnect with one's masculinity and thereby reclaim the independence demanded of citizens. ${ }^{244}$ What the continentalists proposed to do was to use the free continental market in order to regenerate Canadian society and to restore the economy from its current "feminine" state.

This connection becomes evident in the language of gender as it was attached to the structure of the economy by the continentalists. The current system of the National Policy and the ideas of the Imperial Federationists were always described as "sensitive". Those who resorted to the loyalty cry, according to Lockhart Gordon, did so in part because they were "super-sensitive". ${ }^{245}$ As early as 1881 , Wiman argued that it was "sentiment" and the "loyalist myth" that led to a fear of American domination. ${ }^{246}$ Goldwin Smith called the preference for English goods a kind of "naïve sentimentality."247 Richard Cartwright went so far as to call conservatism the "feminine element" in Canadian society and subsequently declared that liberalism was the "masculine element."248 The explicit implication was that the Liberal-Conservative party was the "neutered" gender and as such both infertile and impotent. ${ }^{249}$ The biological bent of the language clearly betrays concerns about the efficacy of the National Policy to both

\footnotetext{
${ }^{243}$ See Gail Biederman, Manliness and Civilization: A Cultural History of Gender and Race in the United States, 1880-1917, (Chicago: University of Chicago Press, 1996).

${ }^{244}$ Tina Loo, "Making a Modern Wilderness: Conserving Wildlife in Twentieth Century Canada," in Canadian Historical Review 82(1), March 1 2001, 96.

${ }^{245}$ Adam, 99.

${ }^{246}$ Erastus Wiman, The union of telegraph interests in Canada [microform]: a letter to the shareholders of the Montreal Telegraph Company. (New York?: s.n., 1881), 5.

${ }^{247}$ Goldwin Smith, Canada and the Canadian Question, 193.

${ }^{248}$ Cartwright, Speech to Young Liberal Club of Seaforth,7.

${ }^{249}$ Ibid.
} 
provide for the material well being of the population, as discussed above and also to ensure the continuation of the manly, independent element in Canadian society.

This construction of the existing economic order as feminine and consequently weak found further expression in the language of independence and dependence. Legally and politically speaking, men, in the nineteenth century, were the independent members of the household while children and women all constituted dependants. Thus, the claim that Canada behaved as a "dependency" rather than an independent country was a reflection of Canada's youth, but for continentalists it also served as a reflection of its weakened, feminine status. For Goldwin Smith, continued promotion of Imperial Federation or other products of sentimentalism moved Canada in the direction of a colony, or "dependency."250 The only way to avoid dependency, according to Smith, was "to develop in the hearts of the Canadian people that national spirit... of independence which must some day permit Canada to take its place among the great nations." ${ }^{251}$ W.H. Lockhart Gordon said that the loyalty cry made Canada a "colony and dependency."252 For Wiman, the achievement of reciprocity would be a sign that Canada had grown independent and self-reliant. ${ }^{253}$ Smith also felt those who favoured commercial union or a continental policy would thereby display a sense of self-reliance..$^{254}$

The references to "self-reliance" were not coincidental. Not only did it speak to a desire to masculinize economic activity and Canadian society, but it was an allusion to the essay by Ralph Waldo Emerson of the same title. In Self-Reliance, Emerson argued for

\footnotetext{
${ }^{250}$ Goldwin Smith, Political Relation of Canada to Great Britain and the United States, 8.

${ }^{251}$ Goldwin Smith, Canada and the Canadian Question, 108.

${ }^{252}$ Adam, Handbook of Commercial Union, 101.

${ }^{253}$ Erastus Wiman, Commercial union between the United States and Canada [microform]: some letters, papers and speeches. (New York: E. Wiman, 1887), 19.

${ }^{254}$ Adam, Handbook of Commercial Union, xii.
} 
self-regulation and independence in economic affairs as a sign of maturity and masculinity. Wiman even quotes Emerson regularly in his writings. ${ }^{255}$ Thus, it is clear that references to independence were targeted not just at the whole of civil society, but also at its individual members as an implied injunction to govern themselves properly and effectively in order to avoid becoming dependent. What is even more fascinating is that this rhetoric was also used by protectionists to justify their policies. Thus, it is clear that there was little real disagreement between the Macdonaldian protectionists and the continentalists over the actual objectives of the Canadian governmental project; rather, what they diverged on was the matter of strategies and tactics.

While the continentalists often pointed with enthusiasm to the closer ties between Americans and Canadians that had emerged as a result of the one million Canadians who had emigrated to the United States since 1867 , there was a fear that underlay this excitement. ${ }^{256}$ Goldwin Smith felt that the National Policy, by retarding Canadian economic development, was forcing individual Canadians into "economic and social annexation" to the United States. The term annexation had negative connotations for many continentalists as to them it implied a surrender of independence. That is why they preferred the term "political union" in many of their writings. ${ }^{257}$ Cartwright worried continually about the outflow of population as an economic cost to the Canadian community and as a degradation of the Canadian bloodline. ${ }^{258}$ Cartwright's concern was heightened because "everyone who pays attention to the character of that emigration

\footnotetext{
${ }^{255}$ Erastus Wiman, Chances of success: episodes and Observations in the Life of a Busy Man, (Toronto: W. Briggs, 1893), 11

${ }^{256}$ Goldwin Smith, Canada and Canadian Question, 45-47.

${ }^{257}$ Adam, Handbook of Commercial Union, xvii.

${ }^{258}$ Ibid., 8-10.
} 
knows...that in a most unusual proportion they are the very pick and choicest portion of our population."259 S.H. James echoed Cartwright by saying that the emigrants were the “...most robust, energetic and intelligent of our young men who now remove to the states." ${ }^{260}$ Cartwright also pointed out that the emigrants were mostly male. ${ }^{261}$ For Wiman, Canadians were busy engaging in "personal annexation" while political annexation was being debated. ${ }^{262}$

The concern was about the number of quality men leaving the country. The continentalists were worried, certainly, about a sufficient labour supply, but on a cultural level they were concerned about the degeneration of Canadian economic activity into more "feminine" or "sentimental" state. If this kind of economic behaviour persisted, the fear was that Canada would become a country full of dependent rather than independent citizens. Economic "flunkeyism" would dominate Canadian economic culture and the process of state governmentalization would fail due to the absence of strong masculine sons and fathers to continue the process of biologically strengthening the Canadian population and instilling values of independence among its members. ${ }^{263}$ Here also is the implication that not only the whole of civil society, but the individual as well, must work to govern itself in order to avoid degenerate political and socio-economic behaviour.

Historical writing would seem to indicate that the fears of continentalists regarding the economic price of Canadian emigration were well founded. According to Permeable Border by John Bukowczyk published in 2005, the Great Lakes basin was a cultural

\footnotetext{
${ }^{259}$ Ibid., 14.

${ }^{260}$ Ibid., 91.

${ }^{261}$ Sir Richard Cartwright, Speech at Ingersoll, 3.

${ }^{262}$ Erastus Wiman, Closest Trade Relations, 13.

${ }^{263}$ Goldwin Smith, Loyalty, Aristocracy and Jingoism, 22.
} 
middle ground between Canada and the United States. ${ }^{264}$ This border experienced a huge $\mathrm{ebb}$ and flow of humans during the nineteenth century. ${ }^{265}$ As was mentioned in chapter two, between 1880 and $1900,22 \%$ of the Canadian population voted with their feet and annexed themselves to the United States. ${ }^{266}$ However, it was the choice to gender this debate in terms of dependence and independence which reveals the more deeply rooted social anxiety on which continentalism drew in order to critique the governmental tactics of the Macdonaldian system.

Despite repeated allegations, especially during the election of 1891 , that continentalism was treason, it is clear, based on the above evidence, that what continentalism aimed at was a change in the tactics used by the Canadian state to organize and supervise socio-economic relations. It opposed the supposed corrupt practices of patronage and favouritism prevalent in the Macdonald administration. Macdonald and his party were even referred to by Cartwright as "carrion-devouring vultures". ${ }^{267}$ In all likelihood it was these wider republican promises of political regeneration and anti-elitism that resonated with Ontarians, especially those engaged in farming who, as we shall see, in chapter four, were already well versed in the language of civic republicanism.

\section{The Nation and the State}

Turning now to our third branch of counter-conduct, that of the nation against the state, it must be understood as a counter-conduct focused on opposition to the claims of

\footnotetext{
${ }^{264}$ John J. Bukowczyk et al., Permeable Border: The Great Lakes Basin as Transnational Region, 16501990, (Pittsburgh: University of Pittsburgh Press, 2005), 2

${ }^{265}$ Ibid., 7.

${ }^{266}$ Ibid., 110-111.

${ }^{267}$ Cartwright, Speech to the Young Liberal Club of Seaforth, 8.
} 
sovereignty made by the state. Sovereignty denotes the authority of the state to define the semi-sacral national territory, and effectively to ensure that those living inside it identify themselves as members of the particular nation and that those outside do not. As has already been shown in chapter two, the large community of Canadian immigrants in the United States represented the first challenge of the nation against the state as a result of its very existence and definition as Canadian. This transgression of the national territorial boundaries brought into question the authority of the state, as organized by the Conservatives, to speak for and define the nation. Just as the counter-conducts of the population and civil society implied a mismanagement of the well-being of the population and the moral character of Canadians, respectively, the counter-conduct of the nation implied a failure by the state to properly establish its sovereignty against outside influences as well as its ability to establish internal sovereignty over the maintenance of identity.

One of the most effective arguments put forward by the continentalists in this respect was the juxtaposition of the physical and ethnic boundaries of the nation to the juridical boundaries established by the Macdonaldian system of governance. To this end, continentalists were fond of pointing out the inconsistency between the physical and political map of North America. As one interview with Wiman and Smith, published in the Pall Mall Gazette of London, England reminds us, physical geography was considered central, if not decisive, to the continentalist argument. "Every Unionist has a huge map hanging on the wall."268 What these "unionists" did to the maps was another matter.

\footnotetext{
${ }^{268}$ Sir Henry Norman, Commercial union as photographed by an intelligent English visitor to Canada $1888), 5$. [microform] : imperial interviews, number ten, in the Pall Mall gazette. (New York: E. Wiman,
} 
Rather than using them to draw the boundaries of Canada, they were drawing four (sometimes five) distinct north-south blocks separated from each other. ${ }^{269}$ These, according to continentalists, were the real economies of North America shaped by the physical geography of the continent and not the "absurd imaginary line" that lead to "the customs house nuisance." 270

Continentalists had other unflattering names for the political-cum-economic boundary of Canada, including the "barbed wire fence," an image borrowed from Ralph Waldo Emerson. ${ }^{271}$ Thomas Shaw was more focused: "Take a map of the North American continent, examine it carefully, note well the physical conditions of the two countries and you cannot but be convinced of the short-sightedness of the men who are trying to keep Canada and the United States apart for purposes of trade."272 As Goldwin Smith summed it up: "The economy takes no notice of political lines."273

Remembering that the economy is no real thing, but rather, an imaginary for explaining and governing everyday social relations amongst the members of a society, the continentalists were using the prevalence of economic relations as dictated by the physical geography of the continent to question the juridical border of the Canadian state. They accomplished this by highlighting that a significant portion of the nation and its social relations were beyond its jurisdiction. As Smith succinctly put it: "Few have fought against geography and prevailed."274 The continentalists confronted the Macdonaldian

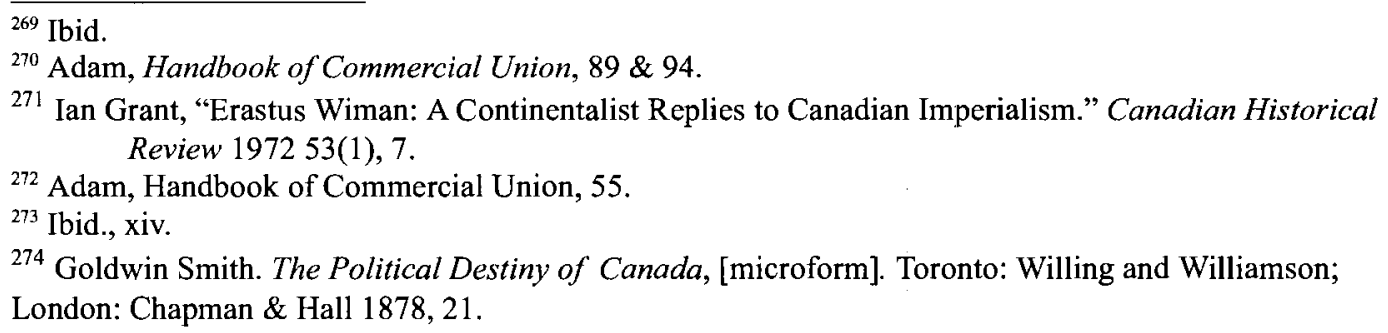


definition of the nation with the definition implied by physical geography and what they perceived as the natural flows of economic and social life, flows reflected in the age-old movement of people identifying themselves as Canadian across the Canadian-American border. In short, they saw the nation as pre-dating, independent and in direct conflict with the authority of the state. Furthermore, they placed geography and the market economy - along with the nation made by these two forces - prior to and outside the existing political structures of the North American continent. As the following quote illustrates, this line of argument surely undermined claims by the state to define the nation along juridical lines:

Did nature ever intend that artificial barriers should be placed where only an imaginary line separates us? I would suggest that the Commercial Union Club hang on its walls a map of North America, on which there should be a black line, drawn broad and deep along the boundary line between Canada and the United States, so that the absurdity may clearly appear of trying to keep apart two portions of the same continent which nature intended to be commercially one. Then if you like, run a red line round the outside boundary of both showing the vastness of the country we should have to trade in were the boundaries thrown down, and on the heading of the map place this motto which should also be the motto of our Club, 'Let us have free trade with our own continent, our natural market!'275

The statement about the naturalness of the economic and, by extension, political community is also a central tenet of the civic republican tradition. According to civic republicanism, the political community takes its form from its historical attachments, in this case to the continent, rather than from the attempts by modern fiat to render it separate and independent of that history. ${ }^{276}$

${ }^{275}$ Adam, Handbook of Commercial Union, 85

${ }^{276}$ Smith, Politics and Rememberance, 6 . 
This reinforcement of a definition of nation that defied the juridical boundaries set by the Canadian state was not the only continentalist definition of nation entertained. Continentalists also established a continental and trans-atlantic definition of nation along the lines of ethnicity and historical lineage. Anglo-Saxonism was used to undermine claims made by the Canadian state that the nation was separate from either the United States or Great Britain. This expression of ethnic nationalism found its roots in part in the philosophy of Social Darwinism. Social Darwinism was an ascendant feature of the nineteenth century. As an adjunct to empire, it envisioned certain races to have predetermined biological capacities and traits which established them in a hierarchical relationship with other races. Social Darwinists like Herbert Spencer were also harsh critics of the modern corporation and the bureaucratization of society. ${ }^{277}$ In most respects, the contemporary world power relationships became the proof of one racial group position in the hierarchy in relation to another. It was common for most Social Darwinists to place the Europeans at the top of the hierarchy in general and, for English writers, the "Anglo-Saxon race" at the very apex of civilization. ${ }^{278}$

Social Darwinism was a strong current among most of the continentalists. Goldwin Smith, in "The Greatness of England" written in 1879, argued that the greatness of England was due to the prevalence of Teutonic blood in the English part of Great Britain. ${ }^{279}$ The other regions lagged in development due to the imperfect assimilation of the "lazier" Celtic blood, which for Smith included the Irish, Welsh and Scottish

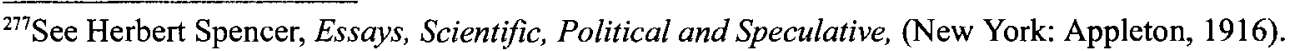
${ }^{278}$ Edward P. Kohn, This Kindred People: Canadian-American relations and the Anglo-Saxon idea, $1895-$ 1903, (Montreal: McGill-Queen's University Press, 2004), 3-4

${ }^{279}$ Goldwin Smith, The greatness of England [microform]. (S.1: s.n., 1879), 2-3
} 
highlanders. ${ }^{280}$ In commenting on imperial federation, Smith wrote that such a federation of the British Empire would "violate the racial hierarchy." 281 He went on to make distinctions between white colonies capable of self-government and other dependencies, like India, which due to their lack of Anglo-Saxon heritage could never be trusted to govern themselves. ${ }^{282}$ The French were equally problematic for Smith as they were a “... relic of the historical past, preserved by isolation as Siberian mammoths are preserved in ice." 283 While continentalists differed as to their explicit endorsement of the kind of racial and ethnic exclusivity ${ }^{284}$, they tended to agree with Smith's assessment that Canada and the United States represented "One people, under two governments with a customs line drawn across it." 285

Anglo-Saxonism was a convincing reply to the Imperial Federationists and Macdonaldian nationalists alike. Anglo-Saxonism envisioned a Canada that shared with both the United States and Great Britain a kind of common past, and in the case of the former, a common future. Despite accusations by Imperial Federationists that continentalism was anti-imperial, it was in fact an implied racial and cultural imperialism, rather than an explicit economic and political arrangement. Despite Carl Berger's fondness for polarizing the debate between continentalism and imperial federationism, it is clear that in many ways, both shared an ethnic exclusivity in response to the ethnic pluralism of the Macdonaldian nation. ${ }^{286}$

\footnotetext{
${ }^{280}$ Ibid., 10.

${ }^{281}$ Goldwin Smith, The political relations of Canada to Great Britain and the United States, 11.

282 Ibid, 8.

${ }^{283}$ Goldwin Smith, The Political Destiny of Canada, 10.

${ }^{284}$ Erastus Wiman tended to see French Canadians as racially different but also as important members of society. This was perhaps a result of his early career in Montreal.

${ }^{285}$ Goldwin Smith, The Political relations of Canada to Great Britain and the United States, 14.

${ }^{286}$ See Carl Berger, The Sense of Power.
} 
Continentalists often lamented that the National Policy "alienated" Canada from the British Empire because it erected duties against British goods as well. ${ }^{287}$ Similarly, it was Anglo-Saxonism that was used to justify Canada's "birtluright" to decide its own destiny in line with "patriotism" and English freedom. ${ }^{288}$ Also, it was reasoned that Anglo-Saxons wanted good relationships between the "two branches" of the Anglo-Saxon family and that it was the duty of Canada to draw England and the U.S. together. ${ }^{289}$ Furthermore, achieving free trade would allow "Nature's inexorable law, 'The survival of the fittest," to operate. ${ }^{290}$ It provided Canada not only with a continental, but also an international and national mission: something almost identical to the supposedly "nationalistic" implications of the imperialist ideas during this period. ${ }^{291}$ Furthermore, many felt that capital and trade in general had a racial or cultural component to it. As Lockhart Gordon argued, there was no point in going all over the world looking for trade when Canadians could trade with those who had similar laws, institutions, language and customs. ${ }^{292}$ T.D. Ledyard asked "why the inhabitants of this great continent, who are the same race, the same language, the same religion, and the same interests, should interpose hostile tariffs against each other."293 Thus, Anglo-Saxonism, by invoking a transnational ethno-cultural identity, further undermined the claims of rational government to ultimate authority in defining the boundaries of the nation.

\footnotetext{
${ }^{287}$ Adam, Handbook of Commercial Union, 34.

${ }^{288}$ Ibid., 99 .

${ }^{289}$ Ibid., 140.

${ }^{290}$ Ibid., 99.

${ }^{291}$ See Carl Berger, The Sense of Power.

${ }^{292}$ Adam, Handbook of Commercial Union, 108-9

${ }^{293}$ Ibid.,85.
} 
Just as Anglo-Saxonism pointed towards shared interest and shared destiny amongst Canada, Britain and the United States, which predated state authority, it provided a framework to explore Canadian Anglo-Saxon identity in relation to the two other major "branches" of the Anglo-Saxon family. As such, it also fulfilled the role of encouraging Canadians to govern themselves in a particular way. Continentalists defined Canadian economic characteristics in juxtaposition to the economic characteristics of Americans as a means of stressing the corrupting effects wealth could have on civic virtue as well as the need for self-governance amongst members of a political community.

The continentalist image of Americans was often one that emphasized their economic characteristics. To borrow from Cartwright, Americans were the adept consumers who would "... buy the apple off the tree, the crop off the ground, and the unborne [sic] foal." ${ }^{9294}$ For Lockhart Gordon, the explanation was that greater wealth inevitably leads to greater consumption, implying that to be American was also to be wealthy. ${ }^{295}$ For Smith, America had the money and manufacturing that was necessary. ${ }^{296}$ This would seem on the surface to contradict the continentalist opposition, rooted in civic republican thought, to artificially supported manufacturing in Canada. However, American manufacturing was seen as a "natural" occurrence, resulting from their large "national" market. Furthermore, this line of argument also became an avenue by which to underscore the gulf between the civic republican ideal and the actual republicanism that operated in America.

\footnotetext{
${ }^{294}$ Ibid., 24.

${ }^{295}$ Ibid., 106.

${ }^{296}$ Goldwin Smith, Speech of Mr. Goldwin Smith, at the banquet of the Chamber of Commerce of the State of New-York, 5.
} 
For Wiman, Americans and Canadians represented two brothers sharing the same language and same lineage. ${ }^{297}$ Yet, he was adamant about pointing out their economically different, yet complementary, roles. For Wiman, nothing could compare with the "extravagance and liberality" of American tourists. ${ }^{298}$ This was contrasted with the Canadians possession of the traits of "sobriety and intelligence." ${ }^{299}$ Furthermore, unlike Americans who were often the employers, Wiman held that Canadians were "employees" who practiced frugality and were "...reliable, steady, and honest..." which made them particularly suited to "...positions of very great trust and responsibility..."300 Canadian were also more "...assertive, self-sufficient and political..." than Americans. ${ }^{301}$ In short, Canadians made better republicans, tied more closely to their land and less corrupted by the effects of wealth, themes that were firmly rooted in the civic republican tradition.

Thus, the continentalists placed Canadians into a mutually beneficial economic relationship with the United States based on shared language and heritage, but also rather ingeniously as a result of differences in economic identity. Significantly, this characterization of Canadians was limited only to those Canadians of Anglo-Saxon descent. Continentalists were articulating a notion of Canadianess, which critiqued the pluralism of liberal individualism, insisting instead upon the necessity of being ancestrally tied to the political community. In many respects, Quebec, the Irish, and other groups fell outside continentalist vision of the ethnic nation. There was at this time a parallel movement for continentalism in Quebec. However, this movement, though similar in

\footnotetext{
${ }^{297}$ Wiman, Capture of Canada, 7.

${ }^{298}$ Wiman, Closets Trade Relations Between Canada and the United States, 8.

${ }^{299}$ Erastus Wiman, The Canadian Club, its purpose and policy [microform] : as set forth in the speech of Erastus Wiman, president, Dominion Day dinner, July 1, 1885. (New York: s.n., 1885), 6-7

${ }^{300}$ Ibid., 7\&9.

${ }^{301}$ Wiman, Closest Trade Relations between Canada and the United States, 36.
} 
some ways, employed a different discourse in the realm of the nation than the AngloSaxonism of the Ontario movement.

Aside from the traits held to be "Canadian" by Wiman, what was the overall shape of this new trans-national economic relationship? The continentalists believed that too much competition was destructive and wasteful, while monopoly was held to be immoral. ${ }^{302}$ As such, Wiman puts forward a third option called the economics of "cooperation". Canada had certain naturally occurring advantages in both its people and its land. By sharing them with other countries which had different advantages, but similar interests based on heritage and culture, continentalists believed the best possible economic outcome could be achieved by both countries. ${ }^{303}$ Smith agreed in principle, stating that one could not hurt another nation without hurting their own. ${ }^{304}$ It was this cooperative principle which underscored the continentalists' economic beliefs and their commitment to civic republicanism's emphasis on the common good and the interdependence of individuals rather than the autonomy of the individual. For the continentalists, the imaginary of the economy, rather than implying the autonomy of individuals, became a metaphor for their interconnectedness across political lines. That this co-operative principle could operate between classes as well inspired Wiman's declaration that commercial union was the economic solution most in accordance with social justice. ${ }^{305}$ The co-operative principle also invoked images of community as central to the proper conduct of life: a further theme from civic republican political thought.

\footnotetext{
${ }^{302}$ Michael Bliss A Living Profit: Studies in the Social History of Canadian Business, 1883-1911 (Toronto: McCLelland and Stewart, 1974), 33-35.

${ }^{303}$ Wiman Chances at Success, 336-337.

${ }^{304}$ Smith, Loyalty, Aristocracy \& Jingoism, 67.

${ }^{305}$ Wiman, Chances at Success, 338.
} 
Therefore, it is clear that it was not only natural factors that continentalists saw unifying the interests of Americans and Canadians, but also cultural ones. Goldwin Smith was not making a simple passing observation when he pointed out that Canadians and Americans shared the same institutions and even read the same magazines. ${ }^{306}$ He was articulating the broadly conceived counter-conduct of the nation by stating that trade no longer followed the flag, but instead it followed the people. ${ }^{307}$ By disassociating the economy from the state even further through the creation of a trans-national identity of Anglo-Saxonism and an accompanying ethnocentric historical mission to promote economic co-operation and reconciliation between the two great "branches" of the family, continentalists were further undermining the Macdonaldian system of governance and promoting in its place an alternative governmental order rooted firmly in a civic republican value system. This was essential for their overall governmentalizing vision which aimed not simply at improving the material circumstances of Canadian society, but also at governmentalizing the state along different lines.

While the above three sections provide a window into the deeper concerns of continentalist thought at its most articulate and most elite, the question remains whether the discourse persists along similar lines in more popular sources. As such, the attention of this thesis is drawn down the ladder of intellectual virtue to the popular press and its particular rhetoric and discourse of continentalism.

\footnotetext{
${ }^{306}$ Goldwin Smith, Canada and the Canadian Question, 26-41

${ }^{307}$ Adam, Handbook of Commercial Union, 20.
} 
Getting the Word Out: Continentalism and Popular Audiences

Before delving into an analysis of the language of popular continental sources, it is necessary to discuss the tactics used by the intellectual elite of the movement to disseminate its message. It must be stressed that, as complex and rich as many of the arguments are in the Handbook for Commercial Union and the other documents referenced above, such documents above were designed not only to be read, but used by those seeking to further the aims of the movement. While no internal documentation survives detailing the activities of the Commercial Union Club (C.U.C.), established in the later half of 1887 in Toronto by Smith and the eclectic band of intellectuals discussed above, the documents from its successor, the Continental Union Association of Ontario (C.U.A.O.) established in 1892 , as well as some news reports of the activities of the likes of Smith and Wiman, do survive. Based on the continuity of membership among the members and officers of both institutions, it may be reasoned that the methods for disseminating the ideas of continentalism were similar.

What is clear from the historical record is that both the C.U.C. and the C.U.A.O. believed that the success of their movement would depend, in the words of one member, on "organization and open discussion conducted in a friendly manner." 308 Between 1887 and the 1891 election, Wiman, Farrer, Smith and others all kept busy speaking schedules throughout Canada and the United States in an effort to build support for the movement. ${ }^{309}$ Many of the speeches given were modified versions of those included in the Handbook. However, speeches were not the only method. Just as the C.U.A. offered copies of the

\footnotetext{
${ }^{308}$ J.E. Ewen to Walter Dymond Gregory [letter], 25 October 1892, Walter Dymond Gregory Papers, Box 1, Queen's University Archives (QUA), Kingston, ON.

${ }^{309}$ Pennington, 108.
} 
Handbook to interested parties, the C.U.A.O. offered free mailings of literature to those who either identified themselves as being interested or identified others as being sympathetic to the cause. An 1892 letter from E.A. Brickman, a recent convert to the movement for political union, showed the usual process. After describing himself as sympathetic to political union, Brickman offered a list of those in his local community he thought would be favourable to political union and requested mailings on their behalf. ${ }^{310}$ Sometimes the responses were favourable, such as that of William Anderson, who declared in a thank you letter to T.M. White, the Secretary of the C.U.A.O., that "I have read the papers you sent carefully and I heartily endorse this movement." ${ }^{\text {111 }}$ Anderson closed his letter with a list of eleven names to whom he encouraged the Association to send mailings. The hope of those committed to the movement was that, where enough men could be brought over to the cause, branches of the C.U.A.O. could be set up..$^{312}$

The dissemination of missionary documents like the Handbook of Commercial Union was central to the continentalist cause. However, it must be remembered that missionary documents like The Handbook represented the most sophisticated embodiment of continentalist thought. It was newspaper and magazine editorials and speeches across rural Ontario and the urban centres of the United States that were the main mode of spreading the discourse to a popular audience and engaging the popular audiences in a debate about the merits of continentalism.

\footnotetext{
${ }^{310}$ E.A. Brickman to T.M. White [letter], 3 November 1892, Walter Dymond Gregory Papers, Box 1, Queen's University Archives (QUA), Kingston, ON.

${ }^{311}$ William Anderson to T.M. White [letter], 30 May 1892, Walter Dymond Gregory Papers, Box 1, Queen's University Archives (QUA), Kingston, ON.

${ }^{312}$ Robert Baker to Goldwin Smith [letter], 9 December 1892, Walter Dymond Gregory Papers, Box 1, Queen's University Archives (QUA), Kingston, ON.
} 
It is important to note that the Handbook was itself partly comprised of edited articles by Goldwin Smith, and Edward Farrer's editorials. Smith's own magazine The Bystander was also instrumental in disseminating the ideas of continentalism. Under the slogan "Not Party but the People," Smith explained to his readers as early as 1880 that there were two commercial policies, the continental and the anti-continental. ${ }^{313}$ According to Smith the anti-continental policy amounted to "commercial jingoism." 314 For Smith, the continental policy that regarded "the American republic as friend and neighbour" made sense because "a sixth of the Canadian nation is already on the south of the line." ${ }^{315}$ When The Bystander was revived in 1889 , Smith was sure to celebrate the fact that Commercial Union literature had been circulating, much to the benefit of the farmer. ${ }^{316}$ The Globe was similarly supportive. When commenting on the establishment of the Central Farmer's Institute for the province of Ontario, which will be discussed in depth in the next chapter, The Globe declared that the farmers had too long agreed to be the "lawful prey" of manufacturers. ${ }^{317}$ Furthermore, it must be remembered that Farrer had worked in favour of the movement while editor of the Daily Mail, as the earlier mention of his editorials indicates. By 1890 he took over the editor's desk at the Globe, signalling for Unionists of all stripes a clear victory and acceptance of continentalism by the Liberal Party. ${ }^{318}$ Certainly, this line of argument presented both in The Daily Mail and

${ }^{313}$ Goldwin Smith, The Bystander, Vol. 1 Iss. 6 June 1880, 278.

${ }^{314}$ Ibid.

${ }^{315}$ Ibid., 280-281.

${ }^{316}$ Goldwin Smith, The Bystander, February 1890, 147 \& December 1889, 81.

${ }^{317}$ The Globe, 30 May 1887, 4.

${ }^{318}$ Ibid., 164. 
later in The Globe was attacked mercilessly by Conservative organs like The Empire as treasonous. ${ }^{319}$

Yet, urban newspapers and magazines were not the major mode of dissemination for a movement that found much of its base among the agrarian population. Another of the continentalists, Thomas Shaw, was central to the dissemination of the discourse. As mentioned above, Shaw had begun as a farmer and quickly moved into journalism. He not only helped found and manage the Farmers' Institute system in 1887 in Ontario with Vallancey Fuller, but acted as its secretary, concurrently editing The Canadian Livestock and Farm Journal before joining the faculty at the Ontario Agricultural College in Guelph in 1888 . The Canadian Livestock and Farm Journal was a monthly publication from Hamilton with a wide Canadian readership, particularly in Ontario. At the time, it was the closest thing to a "national" farm journal publishing advice for farmers on farming and livestock techniques, business practices and, significantly, politics.

Shaw's credentials as a continentalist have been well established above through the excerpts of his contribution to the Handbook and other speeches. As editor of the Canadian Livestock and Farm Journal, Shaw deplored the "lax notions of political morality..." that persisted in Canadian society that resulted in "duty to the state [being] left undone." ${ }^{320}$ Two months later, Shaw made reference to the National Policy system declaring that the farmers should "organize to defend their commercial rights... when [they are]...fleeced by the manufacturer, robbed by the professional man." ${ }^{321}$

\footnotetext{
${ }^{319}$ Carman Cumming, Secret Craft, 154-158.

${ }^{320}$ Canadian Livestock and Farm Journal, Vol. 2 Iss. 1, January 1885, 21.

${ }^{321}$ Canadian Livestock and Farm Journal, Vol. 2 Iss. 3, March 1885, 72.
} 
When useful, Shaw would also resort to language that reflected not only civic republican values, but also referenced the ethnocentric and gendered language of continentalism. In his interpretation of Roman history, for instance, Shaw declared that farmers were the cause of Rome's greatness: "it was when this ceased to be the case, when the better born gave way to the effeminate luxury and idleness of the orient, that the glory of Rome dwindled and her empire died." 322 Avoiding this fate for Canada, according to Shaw, called upon farmers to be “...sober, honest, industrious, [and] judicious..." while displaying "... an unselfish devotion to public duties."

In 1887, the language became more militant and pointed:

...the various interests of the state who have fattened on the oppression imposed upon...the farmer, was on that day placed in the farmer's forge...it will soon be placed on his anvil and smashed in a thousand pieces by the sledge hammer of his unity. ${ }^{324}$

Along with the new militancy, continentalism also came to the foreground of the discussion. As Shaw declared in 1888, "I am persuaded...it is the common interest of consumers and producers to favour a policy of Unrestricted Reciprocity with our neighbours." ${ }^{25}$ A letter appearing in 1890 signed by "A Yeoman" saw that the farmer was "crushed between the two burdens of a protective tariff and the manufacturers of farm implements." ${ }^{326}$

The other major Canadian farm publication, The Farmers' Advocate and Home Journal published by William Weld in London, $\mathrm{ON}$, was equally dissatisfied with the

\footnotetext{
${ }^{322}$ Canadian Livestock and Farm Journal, Vol. 3 Iss. 3, March 1886, 96-97.

${ }^{323}$ Ibid., 97.

${ }^{324}$ Canadian Livestock and Farm Journal, Vol. 4 Iss. 6, June 1887, 520.

${ }^{325}$ Canadian Livestock and Farm Journal, Vol. 5 Iss. 52, February 1888, 55

${ }^{326}$ Canadian Livestock and Farm Journal, Vol. 6 Iss. 71, September 1889, 230.
} 
present economic and political system and, while refusing to endorse any one solution, its use of language to attack faction is telling: "The root to the evil lies in our party system, and nothing short of a revolutionary change can bring about the desired state of affairs." 327 It was not the party system alone that was subject to attacks. The National Policy also came under fire due to the effect "price[s] fixed by rings and combinations" were having on the people. ${ }^{328}$

Thus, in adopting the language of civic republicanism in their attack on faction, corruption and political immorality, the agricultural journals cited here tended to reinforce a couter-conduct of civil society against the state. As we shall see in the next chapter, this particular tradition was instrumental in establishing and broadening the popularity of continentalism and thereby determining the shape of its practices among the agrarian class. Thus, while the intellectual and popular movement both borrowed from the civic republican tradition, they also operated somewhat independently of each other. While the intellectual group stressed continentalism as a panacea to all the ills of Canadian political life, the agrarian populist branch of the movement focused more on the special duty of farmers as the guardians of the republic. As will become evident in chapter four, this distinction had substantial significance for the shape and long-term viability of the movement in Ontario.

Turning our gaze back to our Canadian-American community, newspapers serving the nearly one million former Canadians living in the United States, discussed earlier in chapter two, also adopted the continentalist discourse for their readers. The previously

\footnotetext{
${ }^{327}$ H. George, Farmers 'Advocate and Home Journal, No. 252, December 1886, 354.

${ }^{328}$ Ibid., No. 253, January 1887, 4.
} 
mentioned Canadian-American, published out of Chicago and Minneapolis and distributed throughout the United States, reported on the activities of Canadians living in the United States and delivered updates on happenings from north of the border. The paper was fond of underscoring the similarity between Americans and Canadians: "Not a discordant note was heard during the evening. It was a meeting of men who speak the same language; who come from the same stock; who have much in common..., 329 According to the Canadian-American, Americans were “....ready to do more for the greater half of the American continent, just as soon as tariff laws are made a little more liberal...". ${ }^{330}$ According to the paper, the ties between Canada and the United States were undeniable: "Canada needs our products and we need hers, and both countries put up a tariff wall to prevent interchange...[t] his is worse than stupidity." ${ }^{931}$ The CanadianAmerican even explained how the Canadian population was a benefit to the United States by diluting the scourge of faction in the political community: “....in the Legislature of North Dakota there are twenty-two Canadians. There is no Canadian-American party... Such a thing is unknown where the Canadian population is the strongest." ${ }^{332}$

As is clear from the above, the Canadian-American embodied counter-conducts of the nation, showing how the existence of those declaring themselves Canadian on the American side of the border challenged the juridical boundaries prescribed by both the Canadian and American states. Similarly, the use of Anglo-Saxonism reflects a direct influence of the ethnic dimensions of the national counter-conduct as elucidated by the continentalist thinkers. It is clear from the above that, though removed from the centre of

${ }^{329}$ Canadian American, Vol. 6 Iss. 259, 9 March 1888, 1.

${ }^{330}$ Canadian American, Vol. 8 Iss. 352, 7 March 1890, 4.

${ }^{331}$ Canadian American, Vol. 8 Iss. 253, 14 March 1890, 6.

${ }^{332}$ Canadian American, Vol. 8 Iss. 356, 4 April 1890, 1. 
the Canadian movement for continentalism the Canadian-American adhered closely to the messaging used by the group of intellectuals clustered around Goldwin Smith and Erastus Wiman.

While newspapers did provide a popular medium by which to disseminate the ideas of continentalism widely, the most effective method for encouraging and structuring participation in the movement in Canada was the effort made by several prominent intellectuals, and some others familiar with the arguments of the Handbook and other continentalist literature, to promote the movement through speaking at mass public gatherings. While some of the excerpts above do come from republished speeches, it is the newspapers reports, not just of the content, but of the effect the speeches had that are most interesting. Newspapers of the late nineteenth century were also in the habit of reprinting speeches deemed to be of high quality word for word in their columns. Thus, a speech delivered in front of 400 farmers had the potential to be read by all the subscribers to The Globe.

Among some rural papers, there were interesting examples of this kind of reporting. The Woodstock Sentinel Review, a Liberal paper, reported a speech touching on the themes of Anglo-Saxonism and faction given by Erastus Wiman at the Prince Edward County and Frontenac Farmer's Institute delivered on 7 September 1887. News that Wiman would speak attracted visitors from Belleville, Napanee and as far away as Toronto. ${ }^{333}$ Upon Wiman's arrival at the Picton dock, near the home riding of Mackenzie Bowell, he was greeted by citizens and the Sixteenth Battalion of the militia. ${ }^{334}$ Wiman

\footnotetext{
${ }^{333}$ The Globe, 9 September $1888,1$.

${ }^{334}$ Ibid.
} 
was escorted past the "phalanx" of women lining the streets to the skating rink where he spoke for two hours. ${ }^{335}$ Wiman stated that the United States was Canada's "nearest neighbours and natural allies" and that the plan to open up markets should be supported by "all classes". ${ }^{336}$ Only a day later, Goldwin Smith was echoing Wiman's sentiments at the County of Waterloo Farmer's Institute picnic: “...our interests are closely allied to those of our neighboring states...[who possess] the same tongue and parentage."337

Appearances by the likes of Wiman and Smith were major events in the small communities beyond Toronto. While the speeches were important to the overall popularization of the movement, much of the work of organizing and speaking to the agrarian interests was left to Thomas Shaw, Vallancey Fuller, and Walter Dymond Gregory, a young Toronto-based lawyer and friend of Edward Farrer. Shaw, Fuller and Gregory attended as many agrarian meetings as possible to speak on the issue of commercial union. The detailed analysis of these meetings shall be the focus of the next chapter.

Occasionally, as one Stratford Beacon report shows, those simply familiar with the continentalist literature were more than able to make the case for commercial union. James Trew, at a public meeting in St. Paul, declared that commercial union was "not a political question" and that in many cases the border was "imaginary" and defended by "spoon fed manufacturers." ${ }^{\circ 38}$ Trew's speech received much applause.

What is clear from the tactics, language and efforts outlined above is that not only were the intellectuals responsible for transforming a disorganized resistance movement

\footnotetext{
335 Ibid.

${ }^{336}$ Woodstock Sentinel Review, 9 September 1887.

${ }^{337}$ Woodstock Sentinel Review, 10 September 1887.

${ }^{338}$ Stratford Beacon, 31 January 1888.
} 
into a formal discourse of political protest embracing all three varieties of counterconduct, but that they worked extremely hard to generate grass roots appeal for the movement and participation through the medium of the public meeting. Their success in doing so reflected the prexistence of a broad, inchoate continentalist and civic republican culture in Ontario, one ready to be shaped into a more formal counter-conduct by the affront of the National Policy. Thus, continentalism cannot be understood simply as an irrational outburst at a moment of crisis in Canada's journey from colony to nation. Rather, when examined contextually with an eye to political traditions and the evolving governmentalization of the state, it is clearly a movement concerned with using the tenets of the civic republican political tradition "...conceived in the early moments of the American revolution" to undermine the newly crafted National Policy system as a means to achieve the objectives of the state. ${ }^{339}$ Within the context of nineteenth century Canadian politics, continentalism was the most obvious discourse by which to develop an organized resistance movement to Macdonald's isolationist policies.

While the geneaology of the continentalist movement has been explained, the contours of continentalist thought have been sketched, the contents of their discourse analyzed, and the mode of its dissemination explicated, this is not sufficient to fully grasp the movement and its significance. It is necessary to analyze how this discourse was received and then acted upon by those outside the cabal of continentalist intellectuals. Answering this question will take us into the next chapter where the political practices of continentalism will be examined with a mind to the effectiveness of the discourse in

\footnotetext{
${ }^{339}$ Pennington, 17.
} 
inspiring an active political practice, a true conduct, of continentalism, reaching its climax with the election of 1891 . 


\section{Chapter 4: The Politics of Continentalism}

Ye send our best and brightest forth. our nation's hope and pride More precious to our country's wealth than all her wealth beside; To be the strength of alien states of empire not our own.

And all to "build the nation up" without its corner stone.

Then from the dregs of other lands, the wretched and the weak, Unfit for what before them lies, new sufferings come to seek! Will they give back to Canada the strength she casts away? Will they replace the gallant lads that leave our shores today?

Drag not the generous brave "old flag" into a party cry;

Its folds have waved for freedom oft on many a day gone by; Claim not its name, its grand old fame for tyranny disguised, To hid the need and selfish greed of power and place misprised.

God gave this mighty continent to this our father's race, The north and south He made for all, and crowned them with his grace, That each might fill the other's lack, and love and plenty reign; -What He hath joined together let no man cleave in twain. ${ }^{340}$

"Our Life Blood Ebbs Away: A Plea for Continental Union” in the early 1890s by the enigmatic "Fidelis" is a striking sample of continentalist discourse for several important reasons. First, it is an example of the use of popular literature, in this case poetry, to disseminate the messages of continentalism. The lengthy excerpt quoted above makes reference to the themes of the failure of the Macdonaldian system to provide for the security and well-being of the population. The second and fourth stanzas make reference to the weakness of the Canadian nation as a result of emigration as well as to a divinely sanctioned continental nation, which is the product both of a shared Anglo-Saxon heritage and the contours of physical geography. The third stanza hits upon the themes of

\footnotetext{
${ }^{340}$ Agnes Maule Machar [Fidelis]. "Our Life Blood Ebbs Away: A Plea for Continental Union" [S.I.: S.N., 1890-1892].
} 
corruption, faction and moral degradation in public life, themes often associated with the political tactics of Macdonald's Conservative Party. One notes also that these typical continentalist messages are contained within the unique medium of the poem, not another acrid essay of political commentary.

In short, it is a remarkable example of the consistency of the continentalist discourse among both formal and popular writings. This is especially interesting given the true identity of the author: Agnes Maule Machar. Machar, of Kingston, Ontario was a prolific writer in her time. Her work appeared in many of the very best Canadian publications, including Goldwin Smith's The Week, simultaneously supporting the causes of imperialism, Canadian nationalism and continentalism, while attacking what she saw as "Yankee phobia" among the general population. In her entry in the Dictionary of Canadian Biography, she is defined as an imperialist and nationalist. Yet as the entry goes on to tell us, Machar "...took little interest in the mechanics of nation-building, instead promoting a vision with high moral purpose, purged of sordid party politics and "racial tension," a vision which coincided with the continentalist exaltation of a civic republican governmental order as discussed in the previous chapter. ${ }^{341}$ For Machar, there was no violent contradiction between her imperialism and continentalism; rather, the two represented a way of ending the faction and impurities of party politics in Canada.

Machar's relationship to continentalism is the ideal jumping off point for the exploration of how various state and non-state actors responded to and helped to shape the program outlined by the continentalist intellectuals. Rather than moving from the

${ }^{341}$ Ruth Compton Brouwer, "Agnes Maule Machar", in The Dictionary of Canadian Biography Online, 11 March 2008. http:/www.biographi.ca/EN/ShowBio.asp?BioId=42071\&query=Agnes\%20AND\%20Maule\%20AND\%20 Machar 
discursive formations of continentalism straight to the Liberal policy of unrestricted reciprocity, this chapter will first attempt to highlight the political behaviours and agenda of the agrarian base that made up the bulk of the support for the movement.

While the previous chapter was chiefly concerned with exploring the contours of the discourse of continentalism and its structure as a counter-conduct rooted in the civic republican political tradition, this chapter is interested in tracing the growth of formalized political behaviour. By this is meant explicitly and implicitly political behaviours associated with continentalism. In tracing this evolution, this thesis will move from the editorial offices of newspapers, magazines and the commercial and political union Clubs, to the various meetings held in communities across Ontario in order to generate support for the movement. In short, the focus is on the grass-roots of the continentalist movement. Close attention will be directed not at what was said, as that discussion has already been well documented, but rather at how the meetings were conducted and what they reflected about the effect of continentalism on political behaviour. This is not to say that these practices originated as a result of the discourse of continentalism. Such an assertion, as well as being ridiculously elitist, denies the presence of prior political behaviours among certain groups. Rather, the argument here is that certain political behaviours were complemented and reinforced by the continentalist discourse, particularly those performances which stressed the primacy of community and civil society over the state. The growth of a conduct of continentalism was most robust among groups with a predisposition towards the civic republican tradition: namely, the agrarian class. In keeping with this thesis' commitment to exploring the movement for 
continentalism as a counter-conduct, special attention will be paid to performances that reflect the discourse of continentalism as a counter-conduct.

Performance in this context refers to self-conscious behaviours of individuals and groups which are meant to communicate a particular discourse. Performances then have an element of ritual to them. The implication, is that the location, structure and general conduct is as important as the linguistic portions of a performances discourse. Performances are comprised of several important factors ranging through the spatial location of the performance, the symbols and language employed, the structuring of participation, right down to the organization of their proceedings. For the purposes of exposition, this chapter will cover only those performances up to 1891 . It must be conceded that the discourse, tactics, and even grass-roots performances of the continentalist movement remained consistent and similar in both the political union and commercial union phases of the movement. However, ignoring the chronology of events altogether would result in a misunderstanding of how the movement unfolded. Furthermore, it would skew the relationship between those grass-roots performances and the choice by the Liberal Party to adopt a continentalist policy in 1888 .

Along with tracing the growth of performances of continentalism, the object of this chapter is also to evaluate the effect these performances had on the Liberal Party. In 1888, the Liberal Party adopted a continentalist policy as the main plank of its platform and subsequently fought the election of 1891 on that issue. The assumption by past historians, namely R.C. Brown and I.A. Hodson as discussed in chapter 1, has been that it was the lobbying efforts of the continentalist intellectuals, discussed in the previous 
chapter, that contributed to this shift in Liberal policy. What will be argued here through the evaluation of archival sources is that while such lobbying must have played a guiding role in the ultimate decision, it was in fact the continentalist performances present in agrarian popular culture which played the decisive role in the Liberal Party's adoption of the policy of Unrestricted Reciprocity. Finally, by tracing the campaign of 1891, one should be able to gauge how the counter-conduct of continentalism was changed as the Conservative Party responded to its adoption and promotion by the Liberal Party.

\section{The Farmers' Institutes}

Some of the most important and richest examples of continentalist performances are those of the Farmers' Institutes. Before exploring those performances directly, it is necessary to explain the origins of the Farmers' Institutes in order to understand why they made common cause with the political objectives of continentalism.

There is no historian of the Farmer's Institutes of Ontario. Despite this fact, it is possible to use the few histories on agrarian movements of late-nineteenth century Canada and the United States to develop an account of the roots of the agrarian political agitation of the 1880 s and the Farmers' Institutes. While the Grange movement in the United States was explicitly and aggressively political and republican in its sentiments and outlook, the same could not be said of its Canadian counterpart. ${ }^{342}$ The Grange began as a secret society for farmers which focused not only education for the agrarian classes, but also significantly on the development of voluntary co-operative business endeavours

${ }^{342}$ See D. Sven Nordin, Rich Harvest: A History of the Grange, 1867-1900, (Jackson: University of Mississippi Press, 1974); and Thomas A. Woods, Knights of the Plow: Oliver H. Kelley and the Origins of the Grange in Republican Ideology, (Ames, IW: University of Iowa Press, 1991). 
among farmers. These co-operative ventures held diverse foci from the sale of agricultural products and equipment to banking and insurance. ${ }^{343}$ In the United States, the Grange also became aggressive in the political field, leading a third party movement in the 1880 s and efforts to put pressure on both major political parties to renew their commitment to the ideology of producerism. This ideology had been a foundational theory in the reconciliation between liberal economic and republican concerns about civic virtue and equality. ${ }^{344}$ Producerism, as developed by H.H. Carrey and popularized by the agrarian and labour movements of the nineteenth century United States, held that labour, particularly agricultural labour, was antecedent and superior to capital. In the radical agrarian variant of this more general theory, farmers tended to emphasize the Jeffersonian ideal of the independent yeoman farmer as the backbone of the American political community with their virtue stemming, in part, from a rejection of excessive wealth and their preference for semi-subsistence farming. ${ }^{345}$ The fear of those who advocated the producerist creed was of the tendency for wealth to concentrate, leading to vice and the destruction of equality: necessary components for the maintenance of the republic. ${ }^{346}$ Political efforts on the part of the Grange in the United States were deeply imbued with this republican mission. ${ }^{347}$ What is remarkable and surprising is that unlike their American brethren, the Grangers in Canada refused to become involved in politics in the same way. ${ }^{348}$ While individuals such as Charles A. Drury became involved in the Ontario government, holding the agriculture portfolio throughout the $1880 \mathrm{~s}$, most of the

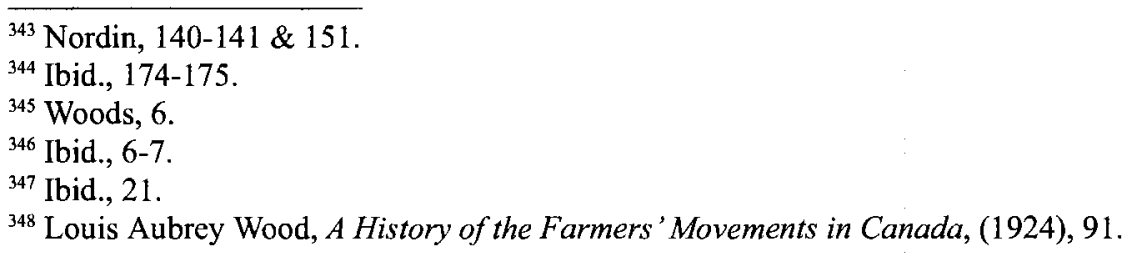


membership remained aloof from party politics. ${ }^{349}$ When the leaders of the Canadian Grange took a stand in the 1870 s in favour of a protective tariff they were surprised by the resistance they received from their own membership, two-thirds of whom would not acquiesce in placing their signatures on petitions in favour of the National Policy. ${ }^{350}$ As early as 1883 , a speech by Master Jabel Robinson attacked the evils of protection before the assembled Dominion Grange. ${ }^{351}$ In spite of widespread suspicion and distrust of protection, the official policy of the Grange did not change until 1895, when it meekly asked for a revenue tariff. ${ }^{352}$ In short, despite the seemingly ambivalent stance of the membership, as an official body, the Dominion Grange tended to shy away from explicit political activities irrespective of its republican institutional heritage.

Rather, most historians who look for agrarian political activism in Canada tend to focus on the Patrons of Industry. While the Patrons of Industry began as an organization in Michigan State and moved into Ontario in the 1890 s, declarations in favour of a revenue tariff were not heard until the fall of $1891 . .^{353}$

The absence of any explicit continentalist declaration from these two high-profile organizations in part led R.C. Brown to conclude that continentalism never enjoyed a significant base of support. ${ }^{354}$ However, most historians neglect the significance of the Farmers' Institutes as a source of agrarian political agitation. Farmers' Institutes were significantly different from organizations like the Grange and the Patrons of Industry in that they were intended to be explicitly apolitical state creations. Farmers' Institutes

\footnotetext{
349 Ibid.

${ }^{350}$ Ibid., 93-94.

${ }^{351}$ Ibid., 94.

${ }^{352}$ Ibid., 94-95.

${ }^{353}$ Ibid., 110 \& 114.

${ }^{354}$ R.C. Brown, 98.
} 
originated out of a desire by agricultural colleges, states and individual farmers to share best practices. ${ }^{355}$ The earliest recorded instances of agrarian organizations that resembled Farmers' Institutes can be found in Massachusetts in 1839. By 1852, the Secretary of Agriculture for the state would make regular speaking tours throughout the state to inform farmers about best agricultural practices. ${ }^{356}$ Similarly, during the winter months in Ontario, farmers would often meet to discuss best practices and methods of conducting different kinds of agriculture in order to maximize profit and increase efficiency. These so-called Farmers' Clubs tended to be unofficial bodies that reflected the rural cohesiveness of mid-nineteenth century Canadian life. ${ }^{357}$ The ethos in favour of transforming these clubs into formal institutes began as early as $1883 .{ }^{358}$ By 1887 in the United States, and a year earlier in Ontario at the urging of the Agricultural College in Guelph, the informal Farmers' Clubs throughout the Province were formally recognized as Farmers' Institutes by Order-in-Council. ${ }^{359}$ The Order-in-Council specified that the Ontario government would offer $\$ 25$ per annum to a Farmers' Institute established in each electoral district where the county council provided matching funds. The guidelines stated that each institute had to have 50 members who paid a fee of $\$ 0.25$ or more. Each institute was to have an executive of nine members, a majority of which had to be farmers. Finally, the institutes had to have a minimum of two meetings each year and submit a report of said meeting to the Secretary of Agriculture for the Province.

${ }^{355}$ Jeffrey W. Moss and Cynthia B. Lass, "A History of Farmers' Institutes", Agricultural History, Vol. 62, Iss. $21988,150$.

356 Ibid., 151.

${ }^{357}$ Annual Report of the County of Brant Farmers 'Institute. 30 June 1886. Annual Report of Farmers' Institutes, Box 1, Archives of Ontario, Toronto, ON. 358 Ibid.

${ }^{359}$ The Permanent Central Farmers' Institute of Ontario, Report of the Proceedings of the First Annual Meeting of the Permanent Central Farmers 'Institute of Ontario, (Hamilton: Griffin \& Kinder, 1888), 5. 
A year later, on 26 March 1887, Vallancey Fuller, President of the Wentworth Farmers' Institute, called for the creation of a Permanent Central Farmers' Institute for the Province of Ontario. ${ }^{360}$ Fuller was the son of a Niagara Bishop and after dabbling in law had found his calling raising pure-bread livestock near Hamilton. ${ }^{361}$ Fuller became successful at his preferred profession, initially selling livestock to the United States and then later by pioneering a new more efficient process for milling flour. ${ }^{362}$ As the Permanent Institute was his idea, it was Fuller who would assume the presidency in the early years of its operation, and along with his Secretary, Thomas Shaw, work to promote continentalism among its membership.

This was despite the official purpose of the Institutes: the professionalization of farming. As far as organizing to defend their collective "commercial rights", Thomas Shaw, the editor for the Canadian Livestock and Farm Journal and Institute Secretary, was seemingly to the point when he declared that the "Institute is not the place for this." 363 Yet, the way that Shaw narrated the development of the Institutes in The Canadian Livestock and Farm Journal and at the first meeting, suggested that in fact the mission of the Institutes was explicitly political and centred around the same kind of agrarian civic republicanism that had led to aggressive political action on the part of Grangers in the United States. Shaw compared the first meeting of the Central Farmers' Institute at Toronto to the first Olympiad of Ancient Greece. ${ }^{364}$ At this first "Olympiad," Shaw explained the mission of the Institutes as ensuring "equal privileges to the yeomen of the

\footnotetext{
${ }^{360}$ Ibid., 5.

${ }^{361}$ I.A. Hodson, Commercial Union, Unrestricted Reciprocity and the Background to the Election of 1891, 89.

362 Ibid.

${ }^{363}$ Canadian Livestock and Farm Journal, vol. 2 Iss. 3, March 1885.

${ }^{364}$ The Canadian Livestock and Farm Journal, June 1887, Vol. 4 Iss. 6.
} 
country," and made specific reference to the Institutes as the proper inheritors of the Grange's mission..$^{365}$

In a paper entitled "The Battle Against the Mighty" that Shaw would commonly read before Farmers' Insitutes, the true vision for the Institutes is revealed. Shaw declared that farmers, unlike their manufacturing brethren, were forced to "...combine for the purposes of deliverance." ${ }^{" 366}$ He argued that the present economic system had led to "... the serfdom of Canadian yeomen...[a group who] never, never, never can be slaves." ${ }^{\prime 367}$ For too long, farmers had "...bowed down and worshiped at the altar of party politics..." ignoring as it were their true "...interests as farmers." ${ }^{\prime 368}$ In practice, it is clear that the Institutes were not the apolitical educational societies they claimed to be. Rather, the Institutes became the centre of an agrarian civic republican agitation which would, as will become clear very shortly, make common cause with the calls for commercial union. This is not surprising given that both movements drew upon and enacted a civic republican counter-conduct. As Honohan reminds us, "republican politics is concerned with enabling interdependent citizens to deliberate on and realize the common goods of a historically evolving political community." ${ }^{\$ 39}$ No more concise statement could be made about what it was the members of the Ontario Farmers' Institutes thought they were doing. Furthermore, by placing the Institutes under state patronage in 1886 , it gave the Institutes legitimacy to speak to political questions on behalf of a large portion of the Canadian electorate. By examining the location of meetings, the process of decision-

\footnotetext{
${ }^{365}$ The Permanent Central Farmers' Institute of Ontario, Report of the Proceedings of the Second Annual Meeting of the Permanent Central Farmers'Institute of Ontario, (Hamilton: Griffin \& Kinder, 1889), 10. ${ }^{366}$ The Canadian Livestock and Farm Journal, April 1888, Vol. 5 Iss. 54.

${ }^{367}$ Ibid.

368 Ibid.

${ }^{369}$ Honohan, 1.
} 
making and the inclusion and exclusion of individuals by the institutes, it will become clear that the themes of community, deliberation and interdependence are reflected strongly in the proceedings of the Farmers' Institutes on the question of commercial union, leading to widespread support for continentalism among the agrarian class.

\section{Inside the Meeting}

The first point worthy of comment regarding the Farmers' Institutes is the venue of many of their meetings. It was common for Farmers' Institutes to gather in buildings like the court house, or town hall to discuss their affairs during the late 1880 s. $^{370}$ Part of the reasoning for the choice of venue may have stemmed from the practical needs of space. However, the farmers also used the official civic architecture of their communities in order to convey not only the legitimacy of their communal aspirations, but the choice of local buildings reinforced the primacy of community and civil society over politicized nationality. When not held in civic buildings, meetings still tended to reinforce the bonds of community. On 8 September 1887, the Waterloo County Farmers' Institute held a picnic to discuss commercial union. ${ }^{371}$ Goldwin Smith was the keynote speaker at the event. ${ }^{372}$ The picnic as an activity was one which tended to reinforce the bonds of community. Furthermore, picnics had long been the preferred venue for discussing political questions. Macdonald used the picnic in his National Policy campaign of the $1870 \mathrm{~s}$ in order to generate support for the new tariff. The choice to come together at civic buildings or in the gathering of a picnic to discuss topics like commercial union was

\footnotetext{
${ }^{370}$ Woodstock Sentinel Review, 2 December 1887 \& Stratford Beacon, 12 March 1888.

${ }^{371}$ Woodstock Sentinel Review, 10 Setember 1887.

${ }^{372}$ Ibid.
} 
evidence of a ritualized performance with blatant civic republican overtones, which emphasized deliberation and the local community as the source of political authority. In both instances, civic republicanism dictated the venue and style of political engagement.

While the location of the meetings is instructive, even more explicit are the general proceedings of meetings. Beginning in 1885 and up to 1888 , almost every Farmers' Institute in Ontario considered a resolution on commercial union. Many of the resolutions debated and passed in local Institutes were based on the "famous" resolution passed by the Wentworth Farmers' Institute. Moved by D.J. Hunter and seconded by D.R. Ellis, the resolution declared:

That in the opinion of this Institute a removal of all restrictions in trade between the Dominion of Canada and the United States is desireable, either by reciprocity or otherwise, as may be agreed upon by the respective countries. ${ }^{373}$

With the generality of the above wording it is no wonder that the wording of resolutions on commercial union often varied greatly from institute to institute. ${ }^{374}$ By the time of the first meeting of the Permanent Central Farmers' Institute from 21-23 February 1888,40 out of 43 of the existing Farmers' Institutes had declared in favour of "unrestricted trade". ${ }^{375}$ The meeting of the North Norfolk Farmers' Institute provides an example of a typical meeting. At the meeting on 4 January 1887 after a speech delivered by Vallancey Fuller, the President and brainchild behind the Permanent Central Farmers'

\footnotetext{
${ }^{373}$ The Permanent Central Farmers' Institute of Ontario (PCFIO), Report of the Proceedings of the First Annual Meeting of the Permanent Central Farmers' Institute of Ontario, (Hamilton: Griffin \& Kinder, $1888), 6$.

${ }^{374}$ Hodson, 98.

${ }^{375}$ The Permanent Central Farmers' Institute of Ontario (PCFIO), Report of the Proceedings of the First Annual Meeting of the Permanent Central Farmers' Institute of Ontario, (Hamilton: Griffin \& Kinder, 1888), 7.
} 
Insitute of Ontario, two local farmers, John Blayney and A.N. Smith, moved and seconded a motion in favour of commercial union or reciprocity with the United States. ${ }^{376}$ Two years earlier at the West Norfolk Institute meeting, a motion was passed in favour of free trade of cattle with the United States. ${ }^{377}$ At the Halton meeting on 9 January 1886 a unanimous resolution was passed favouring the fullest measure of reciprocity with the United States. It is these meetings and the resulting resolutions to which we will now turn. ${ }^{378}$

The great diversity of the language used by the resolutions has been the subject of previous historical inquiry. Historian I.A. Hodson has concluded in Commercial Union, Unrestricted Reciprocity and the Background to the Election of 1891 that farmers did not understand what they were voting for when resolutions on the commercial policy of the Dominion were on the floor. This conclusion is based on a careful analysis of the great variety of motions - some for commercial union, others stressing reciprocity and so forth of which Hodson provides a small sample. ${ }^{379}$ Hodson's conclusion is further enforced by evidence that at some meetings where commercial union motions were passed, the meetings would be concluded with loyal cheers for the Queen. ${ }^{380}$ Even more conclusive in Hodson's mind is the decision by some Institutes to pass motions favouring free trade with both Great Britain and the United States. ${ }^{381}$

\footnotetext{
${ }^{376}$ Annual Report of the North Norfolk Farmers' Institute, 1887. Annual Report of Farmers' Institutes. Box 1, Archives of Ontario, Toronto, ON.

${ }^{377}$ Annual Report of the West Norfolk Farmers' Institute, 1886. Annual Report of Farmers' Institutes, Box 1, Archives of Ontario, Toronto, ON.

${ }^{378}$ Annual Report of the Halton Farmers' Institute, 1886. Annual Report of Farmers' Institutes, Box 1, Archives of Ontario, Toronto, ON.

${ }^{379}$ I.A. Hodson, 98.

${ }^{380}$ Ibid., 129.

${ }^{381}$ Ibid., 102.
} 
The problem with this interpretation is twofold. First, it assumes that the intellectual elite's emphasis on commercial union was the only valid continentalist policy. However, it is the contention of this thesis that farmers and other members of the community could have, and most likely did have, their own views on continentalism. Fuller's use of reciprocity and commercial union interchangeably at least suggests, along with a subtle use of language and the generality of most motions, that the farmers saw the issue in a different light than the intellectual wing. ${ }^{382}$ While related to the intellectual movement, farmers drew more heavily upon the implicit civic republican themes of the intellectual discourse than the literal political prescriptions, emphasizing deliberation and consensus over strong, clearly declared political prescriptions. Discourses are rarely purely literal and one dimensional, but rather are often strategic in both their formulation and their interpretation. Treating them as such turns one's focus away from the words and towards the multiple possible interpretations or reading of those words. In this vein, the literal language of the resolutions is no more important than the way that decisions were made and justified. Just as in our post-modern epoch individuals interpret texts in a multitude of often unintended ways, so too did our distant relatives in the nineteenth century. This thesis will suggest that while the language of the resolutions may have differed, there was a particular process attached to them which shows conscious and deliberate political acts on the part of the agrarian interest. Continentalist agitation was therefore not simply a top-down orchestrated process, but instead the outcome of a dialectic between the bottom-up agitation of the farming class and the intellectual

\footnotetext{
${ }^{382}$ Annual Report of the South Ontario Farmers' Institute, 1887. Annual Report of Farmers' Institutes, Box 1, Archives of Ontario, Toronto.
} 
definition of the issue discussed in chapter three. Furthermore, the variety within the language of the continentalist motions of the Farmers' Institute should be taken not as evidence of ignorance, but rather as evidence of genuine deliberation and the attempt at achieving results not only suitable to a wide majority of the membership, but also a search for genuine consensus on the topic by those at institute meetings, rather than the liberal pursuit of a simple majority.

While Goldwin Smith and the others hoped for the adoption of a continental policy by the state, Fuller and the other more active farming interests, advocated a different approach. At the first meeting of the Permamanent Central Farmers' Institute mentioned previously, Fuller's address offered a contrast to the views held by the movement's intellectuals. Fuller declared "[a]ll motions that in any way savour of, or have any bearing upon, political issues will be carefully excluded from the order paper," and that in this vein further discussions of commercial union would lead to "discord" at a time when "we [farmers] should all be united." 383 By political Fuller meant anything partisan, that is, anything that could lead to faction within the agrarian community. Fuller later moved a motion to end discussion of commercial union within the Farmers' Institutes once it became a party question, fearing that continued discussion after that time would lead to "dissension and wreck to the body." "384 The motion carried 61 to 13 among delegates. The fear of the "wreck" or corruption of the body of farmers' was a reflection to the Institutes blatantly republican roots, as it stressed the virtue of yeoman society and the assumption of interdependence among its members and a resulting need to maintain

\footnotetext{
383 The Permanent Central Farmers' Institute of Ontario, Report of the Proceedings of the First Annual Meeting of the Permanent Central Farmers 'Institute of Ontario, (Hamilton: Griffin \& Kinder, 1888 ), 7. ${ }^{384}$ Ibid, 12.
} 
consensus through debate amongst members of the community, in the face of the constant danger of that debate being hijacked by outsiders who would favour party sentiment over the people.

Turning our attention to the local meetings again shows the depth and strength of this agrarian civic republican ethos. One place where this is evident is in the structure of debate and voting at meetings where continentalism was discussed. The comments of Thomas A. Good, the secretary of the North Brant Farmers' Institute, are typical of descriptions of the decision-making process. Good wrote that “....agricultural subjects are discussed principally sometimes by debate at others by some person preparing a paper to open the subject and he [sic] followed by discussion." Debate and deliberation formed a central part of the decision making process within the farmers' organizations. Prior to voting on the continentalist policy, many Institutes reported a great deal of discussion. ${ }^{385}$ This consensus building process was used not only for the discussion of continentalism, but also deliberation on agricultural concerns, education, railway regulation, margarine manufacturing and so forth.

At a meeting attended by 57 farmers held by the North Norfolk County Farmers' Institute on 23 June 1887, the deliberative process and its relationship to continentalism was made very clear. After John Blayney, the president of the local Institute, introduced a motion in favour of commercial union, it was seconded by another local member, A.N. Smith. Fuller was in attendance and subsequently gave a speech on commercial union. The report of the Institute stated that this motion was carried "after discussion by a large

\footnotetext{
${ }^{385}$ See Annual Report of Farmers' Institutes, Box 1, Toronto, AO.
} 
majority." ${ }^{386}$ Wherever Fuller or Shaw spoke, the norm was that the resolution passed unanimously or with very little dissent. ${ }^{387}$ The temptation to interpret this fact as clear evidence of an elite-managed movement is certainly strong, and it is easy to excuse Hodson for taking the leap. However, if the reports are examined in depth, what becomes clear is that this process was in fact highly democratic, politically engaged and very careful. The goal was to groom a binding consensus or at the very worst a large majority in the votes. For example, at the West Peterborough meeting of the 29 February 1888, W. Cluxton gave a paper on commercial union. The annual report claimed that "discussion ensued" as a result of the paper. ${ }^{388}$ In some instances, this ultimate goal of consensus or near consensus was hard to obtain. At the two meetings held by the Lennox County Farmers' Institute with Thomas Shaw in attendance, two completely different results emerged. At the meeting in Odessa the motion for commercial union was carried by a small margin, while the meeting at Napanee a day later showed a large majority in favour of commercial union. ${ }^{389}$ The difficulty at the Odessa meeting suggests that the membership of the Farmers' Institutes was not merely obeying its organizational betters. Instead the membership was discussing and thinking about the issue in order to arrive at an informed decision.

\footnotetext{
${ }^{386}$ Annual Report of the N. Norfolk Farmers' Institute, 4 January 1887, Annual Report of Farmers' Institutes, Box 1, Archives of Ontario, Toronto, ON.

${ }^{387}$ See Annual Report of Halton Farmers' Institute, 9 January 1886; Annual Report of S. Simcoe Farmers' Institute, 7 January 1887; Annual Report of the N. York Farmers' Institute, 4 June 1887; Annual Report of the S. Renfrew Farmers' Institute, 21 November 1885; Annual Report of the W. Victoria Farmers' Institute, 9 December 1885; Annual Report of the N. Ontario Farmers' Institute, January 1887; Annual Report of the S. Bruce Farmers' Insitute, 1 December 1887 in Annual Report of Farmers' Institutes, Box 1, Toronto, AO. ${ }^{388}$ Annual Report of the W. Peterborough Farmers' Institute, 29 February 1888, Annual Report of Farmers' Institutes, Box 1, Archives of Ontario, Toronto, ON.

${ }^{389}$ Annual Report of the Lennox County Farmers' Institute, 19 December 1888, Annual Report of Farmers' Institutes, Box 1, Archives of Ontario, Toronto, ON.
} 
At the East Hamilton Farmers' Insitute meeting of 20 November 1885 where Members of Parliament were in attendance, the discussion of commercial union was reported to "take up the whole evening."390 At the South Brant Farmers' Institute, a speech by Walter Dymond Gregory, the young Toronto lawyer and member of the Commercial Union Association, resulted in a call for further discussion on the issue. ${ }^{391}$ The above examples provide obvious evidence of a more sophisticated deliberative activity than the one envisioned by Hodson. Rather than merely following the intellectual leadership of the Commercial Union Association blindly, the Farmers' Institutes deliberated on and considered the resolutions before them very carefully and seriously in the majority of instances. The Institutes thus reflected a vibrant agrarian democracy, active on a county-to-county basis and redolent of the mores of the civic republican political tradition. The rising tide in favour of commercial unionism in Ontario was thus a pas de deux choreographed by city thinkers and agrarian elites and debated and groomed at the county grass-roots level.

Furthermore, Farmers' Institutes in some counties took it upon themselves to propagate the commercial union gospel in their wider community. The West Dundas Farmers' Institute held two open meetings in July 1887 and on 2 February 1888.

Vallancey Fuller and Erastus Wiman spoke at the first, while Goldwin Smith took the stage at the second meeting. ${ }^{392}$ The South Oxford meeting of 21 December 1888 included a debate between Vallancey Fuller and J. Castell Hopkins, Banker, anti-American and co-

\footnotetext{
${ }^{390}$ Annual Report of the E. Hamilton Farmers' Institute, 20 November 1885. Annual Report of Farmers' Institutes, Box 1, Archives of Onatrio, Toronto, ON.

${ }^{391}$ Annual Report of the S. Brant Farmers' Institute, 5 December 1885. Annual Report of Farmers' Institutes, Box 1, Archives of Ontario, Toronto, ON.

${ }^{392}$ Annual Report of the West Dundas Farmers' Institute, June 1887, Annual Report of Farmers' Institutes, Box 1, Archives of Ontario, Toronto, ON.
} 
founder of the Imperial Federation League, on unrestricted reciprocity - the name applied to the Liberal Party's continentalist policy. The debate was thought to be so informative that one month later a meeting was sponsored by the Institute for the entire town to attend. ${ }^{393}$ The Centre Wellington Farmers' Institute was particularly ambitious. A paper prepared and read by a local farmer George Wright was deemed to be of such a quality as to warrant its publication in the Elora Express weekly newspaper and for its printing in pamphlet form..$^{394}$ The Institute opted to purchase 100 copies of the pamphlet for distribution. ${ }^{395}$

While the above discussion helps us to understand the role that deliberation played in the agrarian response to continentalism, our attention will now be redirected to the composition of these meetings and the conduct of the discussions in order to demonstrate the self-conception of these mass organizations of farmers.

Inclusion and exclusions form the basis of any community, national or local. While participation in the overarching events of the nation, through direct action or reading about them in the newspaper, form the basis of inclusion and exclusion within the national community of a liberal-nationalist variety, a republic is not so pluralistic in its definitions. Rather, I contend that republican-nationalist inclusion is based upon holding the values of the nation and reflecting them in one's conduct. In short, the republican-nationalist definition of the community is significantly tighter than the liberal. While the liberal vision relies upon plurality and views political debate as the source of community,

\footnotetext{
${ }^{393}$ Annual Report of the S. Oxford Farmers' Institute, n.d., Annual Report of Farmers' Institutes, Box 1, Archives of Ontario, Toronto, ON.

${ }^{394}$ Annual Report of the Centre Wellington Farmers' Institute, 1 November 1887, Annual Report of Farmers' Institutes, Box 1, Archives of Ontario, Toronto, ON.

${ }^{395}$ Ibid.
} 
republican views stress the fractious nature of politics and as such see the basis of community in shared values and pre-political equality. Party politics, in the republican definition, cannot create the stability necessary for the community to survive. This is clear when examining the function of the meetings of Farmers' Institutes.

From the report of the East York Farmers' Institute on their 16 June 1887 meeting, it is clear that commercial union was not only discussed, but included favourable addresses by G.B. Smith, the local Member of Provincial Parliament and Archibald Blue, the Assistant Secretary of Agriculture for the Province of Ontario. ${ }^{396}$ In fact, MPs and MPPs, as well as members of the bureaucracy and professors from the Agricultural College at Guelph were frequent attendees at such meetings. The shrewder of them may have attended because of the sheer power of the agricultural vote in a province still dominated by the business of farming. Others, perhaps, attended due to a genuine sympathy with the agrarian cause or because they themselves were farmers. The professors of the agricultural college often attended as a means to disseminate information on correct farming practices. It is impossible to know for sure which motivations were most salient, but, regardless of the motivation, attendance by such notables had a clearly defined implication for the discourse of continentalism. As was mentioned within the previous chapter, the discourse of continentalism, especially in its more popular embodiments, stressed the virtue and special role of the farmers as a kind of agrarian guardian of the republic's virtue and purity. Thus, within the context of this discourse, the attendance of non-farmers or

\footnotetext{
${ }^{396}$ Annual Report of the E. York Farmers' Insitute, 16 June 1887, Annual Report of Farmers' Institutes, Box 1, Archives of Ontario, Toronto, ON.
} 
elected representatives of the state at a meeting likely signified to the farmers in attendance the continuing primacy of rural affairs in a predominantly agrarian society.

That it was seen this way by the membership of the Farmers' Institute can be inferred from their attitudes towards outsiders who were not farmers. Though the minutes of the meetings are often very cursory, the habit of some institutes of using clippings of the newspaper coverage of their proceedings as minutes has ensured the survival of some more specific details. In these, outsiders were often portrayed in predatory terms. One excellent example is the South Ontario Institute meeting of 1886. At the meeting, the membership was reminded that the manufacturers and Toronto Board of Trade had declared against a continentalist policy. After a paper delivered by Vallancey Fuller debate began. Colonel G.H. Grierson argued that "manufacturers see farmers as their lawful prey." 397 Another unnamed individual stated that "since the inception of the national policy, things had not gone as they should have." ${ }^{\prime 38}$ Another agreed, adding an old producerist claim that "every man must know that farming is the first principle of capital, the very foundation of capital." 399 At that point, a Mr. Larke spoke up, indicating that this talk of commercial union was too nebulous, while that of reciprocity and of annexation were clear terms, the fact that farmers were debating commercial union was evidence that they did not understand what was going on. ${ }^{400} \mathrm{Mr}$. Larke was quickly shut down by the audience once a member of the meeting revealed that he was not a farmer and as such was forbidden from speaking for the rest of the meeting. ${ }^{401}$ Larke, however,

${ }^{397}$ Annual Report of the S. Ontario Farmers' Institute, 1886?, Annual Report of Farmers' Institutes, Box 1, Archives of Ontario, Toronto, ON.

398 Ibid.

${ }^{399}$ Ibid.

${ }^{400}$ Ibid.

${ }^{401}$ Ibid. 
would not let things go, and began to recite government statistics to make his case. $\mathrm{He}$ was interrupted again, and this time the reply was abrasive and to the point. His detractor did not seem to care about government statistics and instead pointed out that all he knew was that "things were better under reciprocity and now they aren't any good." In short, the farmers confronted the expert-produced statistical knowledge of the state with local wisdom of the conditions of the farm. They excluded Larke because he was not a member of their community. In doing so, the farmers were projecting a deeply-felt, if intuitive, sense of their own communal values. A community in which debate could only proceed under the conditions of fraternity and equality. In the shunning of statistical knowledge, the farmers are clearly enacting the counter-conduct of civil society against the state.

As was mentioned in the previous chapter, the rhetoric in the continentalist discourse generated for agrarian audiences implied that others did not have the authority to speak against farmers. This example illustrates how the meaning assigned to agricultural interests and their political roles determined political action within these democratic meetings. What is clear here is a tight definition of community operating along civic republican lines, a definition which sees the agrarian interest not only as the exclusive guardian of virtue, but as a cohesive social group with particular authority to supersede the interests of other groups, especially manufacturers.

The wide variety of resolutions, the seriousness taken in deliberating the issues, as well as the activities undertaken by a few Institutes to inform the public all indicate that the Farmers' Institutes and their membership were formatively engaged in and took joint 
ownership of the continentalist movement as a counter-conduct rooted in civic republicanism. The reasons for their widespread support of commercial union was a case of convergence and accident rather than calculated self-interest. The effects of the depression of the 1880 s aroused memories of the Clear Grit past and led farmers to seek out alternative solutions to their economic situation. Already draped in the language of civic republicanism, continentalism was a natural fit with the political rationality of Ontario agrarian society. They not only listened to and absorbed some of the lessons of the intellectual elite of the Commercial Union Club, but they responded in kind by passing their own resolutions and organizing their own events, by staging their own performances. It is clear that rather than a one-sided power relationship that saw the intellectuals of the movement in control, the movement for a continentalist policy was far more multi-vocal and democratic than previously assumed. The performances engaged in by the membership of the Farmers' Institutes created the impression of a committed base in favour of a continentalist policy. There were important differences between the intellectual movement and the farmers' movement, but the civic republican political culture of the Farmers' Institutes allowed these differences to be accommodated. Rather than casting continentalism as a new way to organize and integrate the nation, the farmers' movement took a much more extreme line in its definition of the boundaries of the political community. While Goldwin Smith and many of the individuals of the intellectual movement chose to think of commercial union and continentalism as a prescriptive system of governance that would benefit all members of the political community, from manufacturers to farmers, the continentalist approach of the Farmers' 
Institutes could be called a farmers' first approach. Rather than succumbing to reconciliation and order between the various "classes" of the community, the Farmers" Insitutes sought to re-establish agrarian values and agrarian supremacy as the backbone of an idealized producerist republic of virtue. They saw themselves as the province's primordial political class - not only as defenders of civic virtue, but also as the class in possession of a higher political authority than other members of the political community by virtue of their occupation. In short, they saw themselves as the guardians of the political community: the ultimate republicans.

Based on the evidence above, it is plausible to conclude that the relationship between the discourse of continentalism promoted by the intellectuals and the activities of the agrarian class was not the relationship of a shepherd to its flock. Rather the discourse of continentalism was crucially shaped by certain practices among the agrarian groups such as those of deliberation and the iconic political role of the yeoman farmer. Furthermore, the presence of MPs and MPPs at their meetings as parts of "the community" meant that agrarian sensibilities and political views were well-known to the politicians of the time, particularly those in the Liberal Party. If the scattered consultations of the Farmers' Institutes provided the alchemy for the rural acceptance of commercial union, what goaded the Liberal Party into its acceptance? As will shortly become evident, the farmers, too, had a large part to play in that turn of events.

The Liberal Party \& the Adoption of Unrestricted Reciprocity

I am afraid that we are doomed to defeat following defeat, unless we come out...in favour of commercial union. There 
is no doubt, there can be no doubt that the feeling throughout the whole country is one of ever growing dissatisfaction at the present condition of things. ${ }^{402}$

Things had not gone well for the Liberal Party in the 1880 s and by 1887 , the Liberal Leader, Wilfrid Laurier was forced to confess the above opinion to his chief Ontario lieutenant and committed free trader, Richard Cartwright. While under the leadership of Edward Blake, the once Premier of Ontario and national leader for much of the 1880 s, the Liberals found themselves on the margin of national power. It was true that for all Blake's convictions, he possessed a near phobia of power, resigning after two years as premier, passing up the Liberal leadership in 1873 to the benefit of Alexander Mackenzie, and then leaving Mackenzie's cabinet after barely a year as minister without portfolio. Blake, despite his temperamental unreliability, managed to secure the position of Liberal leader in 1880 and held it for seven years until 1887, as a result of his mental prowess rather than his political consistency and dependability. Blake's tenure as leader proved a period when the Conservatives consistently defeated the Liberals federally despite a strong and vibrant provincial government led by the Liberal Oliver Mowat. When Blake finally stepped aside in 1887 for a new leader, a young charismatic French Canadian, Wilfrid Laurier, was chosen to replace him.

Laurier's main focus once he assumed the leadership following the 1887 election defeat was to find a winning strategy for the Party. This was a necessity not only for the party, but for Laurier's political future as well. Laurier saw himself as a caretaker leader until Cartwright, or another could take the reins. Blake's departure for England soon

\footnotetext{
402 Wilfrid Laurier to Richard Cartwright, [letter], 8 August 1887, The Cartwright Family Papers [microfilm], MS-1992, Archives of Ontario, Toronto, ON.
} 
disabused Laurier of this notion and obliged him to address the hard, cold reality of leadership. As such, Laurier had to show himself capable of providing strong leadership and results in order to solidify his hold on the party. At the same time that Laurier ascended to the leadership of the Liberal Party, Farmers' Institutes were busying themselves passing resolutions in favour of a continentalist option throughout Ontario. After leading the charge in Quebec against the decision by the Conservatives to execute Riel during the 1887 campaign, Laurier had found himself somewhat in disrepute amongst Ontario's anglophone population, who had supported the decision to execute Riel. As the Liberals first bicultural leader, a campaign centred on economic issues, rather than divisive "racial" issues held the most promise for a breakthrough in Ontario.

It is in this context that the above letter was penned by Laurier to Richard Cartwright, his senior Ontario lieutenant, in August 1887. Further letters indicate that Laurier's warming to the cause of commercial union was a speedy decision made significantly in congress with Cartwright, the known free trader. A letter on 9 September 1887 shows that Laurier had made his decision and had begun to push for decisive action in the new direction. Despite opposition to the plan for commercial union from railway critic and future Speaker of the House James Edgar, among others, Laurier felt the time had come to "...unfurl their [the Party's] colours...". 403 To that end, Cartwright was sent to talk to Blake and Edgar and was given permission to begin stumping on commercial union. All that was needed was a new name to help distance the Liberal policy from the more radical claims of continentalism. With that, the policy of "Unrestricted Reciprocity"

${ }^{403}$ Wilfrid Laurier to Richard Cartwright, [letter], 9 September 1887, The Cartwright Family Papers, MS1992, Toronto, AO. 
- a term coined by Edward Farrer - was born. Thus the new stump speeches of the Liberal Party increasingly contained references to the new policy position and were delivered regularly by Liberal politicians as they travelled around the province discussing the continental policy with Ontarians. It is important to note that Unrestricted Reciprocity was a term nebulous enough to allow it to be characterized as commercial union with strongly supportive groups, and as merely a return to reciprocity among more ambivalent groups.

The policy sounded enough like the calls for commercial union of the Commercial Union Association to allow wholesale borrowing of their views. It was also amorphous enough to garner the support the agrarian groups, most of which had declared in favour of some measure of continentalist policy. In many cases, Liberal rhetoric was borrowed from the less radical Commercial Union Association publications rather than the agricultural journals, both discussed in chapter three.

The content of Cartwright's speech to the House on 14 March 1888 has already appeared in this thesis, as the speech was reprinted in the Handbook for Commercial Union. Yet, at this juncture, it is necessary to revisit the speech as it became the basis for subsequent stump speeches in the 1891 campaign. As such, it is an integral artefact in understanding the Liberal connection to the continentalist brain trust and the farmers' movement. Here we see the real architecture of the continentalist movement. In the speech, Cartwright explains his declaration in favour of a continentalist policy as the result of the "...considerable agitation throughout the Dominion..." 404 Cartwright further implied the civic republican leanings of the agrarian movement by stating that the

${ }^{404}$ Sir Richard Cartwright, Debates of the House of Commons, Vol. 25, 14 March 1888, 144. 
discussion of unrestricted reciprocity “....requires the most mature considerations and the most ample discussion..." 405 To that end, Cartwright thanked the House for setting aside this special day to discuss the matter until it was exhausted. ${ }^{406}$ Cartwright complained of monopolies that "...vex and harass..." as well as the sad plight of the farmers. ${ }^{407}$

Yet, Cartwright's references to the language and procedures of the agrarian movement were also coupled with a rhetoric borrowed from the high politique d'etat with which he was more familiar. He made reference to the distortions of the natural law that resulted from the National Policy, namely the gross exodus of the population as a result of the National Policy. ${ }^{408}$ In that vein, Cartwright used statistics to support his claims, something in which Ontario farmers were less interested. ${ }^{409}$ Cartwright also made arguments regarding the corruption of the Canadian federation that the "bribes" of the Conservatives to bolster his case. ${ }^{410}$ In crafting his argument, Cartwright borrowed from both groups within the continentalist camp, yet the explicit declarations of his speech certainly showed a greater influence from the likes of Goldwin Smith and Erastus Wiman from whom Laurier requested speeches on commercial union to be used by the Liberal Party. ${ }^{411}$

The evidence of the stronger pull of the intellectual movement can also be seen in the political tactics of John Charlton. In the 1889 session, Charlton asked that a map of Canada and the border states be displayed behind the Speaker's chair "...to illustrate the

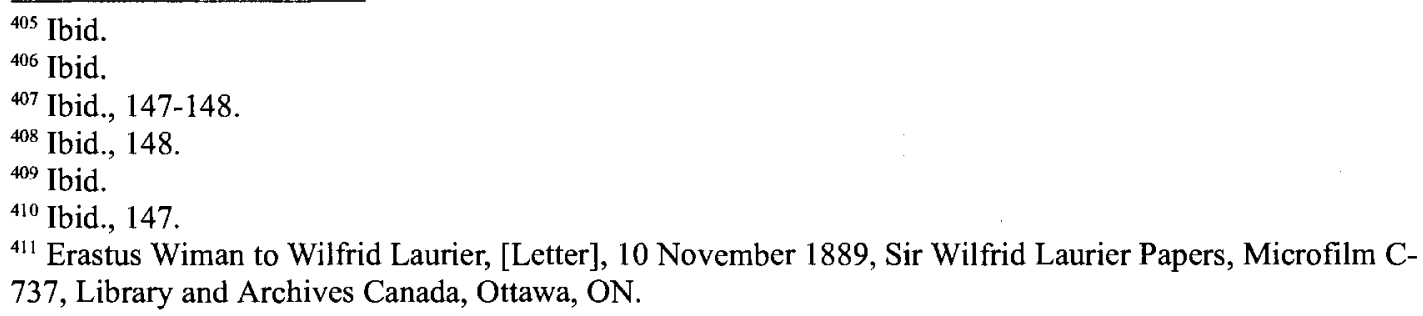


geographical relations of the two countries..."412 The map became a matter of contention as the Conservatives were understandably very reluctant to have it hung while the budget speech was delivered. ${ }^{413}$ In the end, it was hung after the dinner recess for Charlton's speech only. Thinking back to the previous chapter, one recalls that the map of North America was used by the continentalist movement as a symbol to illustrate the geographic unity of the continent and the arbitrary and invalid nature of the political boundaries of both the Canadian and American state. As such, the influence of Smith and Wiman is clearly evident. Charlton even attacked the way that the National Policy system encouraged the "...puny efforts of man to counteract the forces and oppose the decrees of nature...".414 Thus, while Cartwright found a balance between the agrarian and intellectual wings, other Liberals such as Charlton found more comfort in the approaches of Goldwin Smith and Erastus Wiman. As such, it becomes evident that the Liberal Party sought to please everyone with the policy of Unrestricted Reciprocity, but its rhetoric tended to lean more heavily towards the small elitist intellectual wing. It is unclear if this affected its appeal to the large number of potential supporters found amongst the agrarian movement, but it can be reasonably surmised that it certainly did not endear them any more strongly than had previously been the case.

Despite this attempt at a nuanced and calculated policy position, an event south of the border was about to plunge the Liberal Party's policy into even greater difficulties. The first setback to the Liberal policy of Unrestricted Reciprocity came not at the hands of the Conservative campaign of 1891 , but rather from across the border. Unrestricted

\footnotetext{
412 John Charlton, Debates of the House of Commons, Vol. 26, 7 March 1889, 469.

${ }^{413}$ Ibid., 470.

${ }^{414}$ Ibid., 492.
} 
Reciprocity, like any trade treaty, required the collusion of a foreign government. In 1890, the McKinley tariff was signed into law in the United States. This treaty, rather than reducing duties on goods, increased duties to their highest levels of $48 \%$ ad valorem on goods being imported. This new prohibitive duty made successful negotiation of a continentalist trade policy with the United States seem a daunting challenge. This event must have severely weakened the probability of success for the Liberals, and consequently, provided the Conservatives with yet another criticism of the Liberal policy with which to convince voters. The evidence of the impact the McKinley tariff had on public opinion and the concern generated in the Liberal camp is reflected clearly in the content of the Globe. At the outset, the Liberals did their very best to place the blame for the McKinley Tariff on the Conservatives - an understandable American response to Tory protection. ${ }^{415}$ Despite the rhetoric, the Globe editors were keenly aware of the danger the American bill presented to their own policy position: "the bill may be amended to cover a greater number of articles...we exported to the United States last year $\$ 38,490,571$ worth of goods, and it would be difficult to point to any part of this great trade which is not in peril...". ${ }^{416}$ When the bill received assent in the House of Representatives in May of 1890 , the continentalists fought back. Erastus Wiman held a demonstration in favour of closer relations with the United States at Waterloo. ${ }^{417}$ The climax of the demonstration was Wiman's speech titled "The Continental Consequences of the McKinley Tariff Bill." 418 Wiman was dire in his predictions: "If a great war had occurred between the United States and Canada, the result could not have been much worse than the loss which

415 Globe, 16 April 1890.

${ }^{416}$ Globe, 29 April 1890.

${ }^{417}$ Globe, 23 May 1890.

${ }^{418}$ Ibid. 
now threatens to prevail [as a result of the McKinley Tariff]. ${ }^{, 419}$ When the new tariff came into effect on 1 January 1891, the Globe ran a special report on all the Ontario business centres. What it revealed was a severe decline in business as a result of the protective activities of the United States. It both angered and worried the citizens, and did not put Canadians in the mood for conciliation with the United States. ${ }^{420}$ The Liberals had thus crafted a new commercial position, fashioned around an emerging agrarian-intellectual coalition of support only to see it dramatically checked by the deus ex machina of American protection. An opportunity had presented itself, and John A. Macdonald was not about to let it pass him by.

The Election of 1891

In taking account of the election of 1891 , there is much historical writing to be reckoned with in order to view the event with new eyes. The tendency has been for historians to treat the 1891 election as a culminating event in national politics. ${ }^{421}$ Ian A. Hodson's previously cited thesis Commercial Union, Unrestricted Reciprocity and the Background to the Election of 1891 uses the 1891 election as a culminating event in the its narrative of the continentalist movement. ${ }^{422}$ The standard interpretation of the election contained within Beck's Pendulum of Power covers the period between the elections.

${ }^{419}$ Globe, 27 May 1890.

${ }^{420}$ Globe, 1 January 1891.

${ }^{421}$ Several articles which do not focus on the loyalty issue use this periodization. See B. Forster, M. Davidson and R.C. Brown, "The Franchise, Personators and Deadmen: An inquiry into the voters list and the election of 1891." Canadian Historical Review, 67(1) 1986, 17-41; J.R. Miller, "This Saving Remanent: Macdonald and the Catholic Vote in the 1891 Election", Study Sessions 1974 44: 33-52 and "The 1891 Election in Western Canada", Prairie Forum 1985 10(1) 147-167.

${ }^{422}$ I.A. Hodson, Commercial Union, Unrestricted Reciprocity and the Back ground to the Election of 1891. (MA thesis, University of Western Ontario, 1952). Hodson's thesis tends to be highly descriptive of the election campaign and the continentalist movement and erroneously places the end of continentalism in 1891. 
However, the elections take on the role of climax in the narrative structure. ${ }^{423}$ The work of K.A. McKirdy also sees the election as a climactic event in whiggish terms. It too terminates with Macdonald's burial in an American- made casket. ${ }^{424}$ The implication is that continentalism was eradicated by June of 1891 . As such, it is clear that any study hoping to unpack the significance of continentalism and the election must adopt a new periodization that focuses on the election as something other than the climactic symbolic battle between different political view points and programs. What is needed is a history of elections that views them as events that create political realities rather than mere reflections of them.

There are a handful of works in the form of political biographies, such as those on John Thompson and Wilfrid Laurier, that treat the election as linked with what comes before and what comes after. However, because their focus is on historical biography of prominent figures, they are less concerned with how the party politics of continentalism played out in Ontario. ${ }^{425}$ Canada 1874-1896: Arduous Destiny by P.B. Waite is the only serious study of the period of 1891-1896 that does not take the form of biography. However, in its attempt to survey the political landscape of the Dominion in its entirety it provides insufficient coverage of the handling of the election of 1891. Aside from

${ }_{423}$ J. Murray Beck, Pendulum of Power; Canada's Federal Election, (Scarborough, ON: Prentice-Hall, 1968), 57-85. D. Owen Carrigan Canadian Party Platforms 1867-1968, (Toronto: Copp Clark, 1968) though a collection of platform releases implies the same narrative in its structure as that of Beck's work. ${ }^{424}$ K.A. MacKirdy, "The Loyalty Issue in the 1891 Federal Election Campaign and An Ironic Footnote." Ontario History, 1963 55(3), 153.

${ }^{425}$ See J. Castell Hopkins, Life and Work of Sir John Thompson, (Brantford, ON: Bradley Garretson \& Co., 1895); P.B. Waite, The Man from Halifax, (Toronto: U of T Press, 1985); \& Carman Cumming, Secret Craft: The Journalism of Edward Farrer. (Toronto: University of Toronto Press, 1992). There are too many biographies of Laurier to list them all here. They tend though to focus on Laurier's time as PM and particularly the period after the Liberal convention of 1893. 1891 is often framed as an inexperienced Laurier learning an important political lesson the hard way. Consequently the focus of the work is on Laurier rather than the effects of Macdonald's loyalty cry. 
mentioning the Liberal Convention of 1893 and Laurier's successful attempt to get rid of the continental policy at the convention, Waite is all but silent on how the election effected ideas about continentalism. ${ }^{426}$

The only other article which purports to focus on the Liberal response to the loyalty cry is an article by Edward Kohn. In "'The Member from Michigan"” Kohn explores the treatment of John Charlton by the Liberal Party from 1891-1901. Kohn's article makes clear that the Liberals were participating in some internal politics of their own, but does not examine how the election of 1891 effected the viability of continentalism in Ontario politics. ${ }^{427}$

It is the work of Patricia K. Wood that suggests a new approach to the election. In her thesis "Under Which Flag, Canadian?": Anti-Americanism and the Election of 1891, Wood argues that "What all these works are missing... is any real acknowledgement of the role political campaigns can play and have played in forming national identity." ${ }^{28}$ Aside from the discussion of the election as a factor in the development of anti-Americanism in Canada, there is no mention of how Macdonald's anti-American vision found resonance with the Canadian electorate. Rather, Wood simply concludes that "...the sympathetic electorate had absorbed the Conservatives' images of Canada and the Liberals." ${ }^{429}$ In order to understand how the campaign of 1891 impacted the viability of continentalism among the people of Ontario it is necessary to develop connections between the civic republican sympathies of the continentalist base and the rhetoric of the campaign which,

${ }_{426}$ Waite, Canada, 1874-1896: Arduous Destony, (Toronto: McClelland Stewart, 1971), 239.

${ }^{427}$ Edward Kohn, "'The Member from Michigan': The unofficial diplomacy and political isolation of John Charlton, 1892-1903." The Canadian Historical Review. North York: Jun 2001. 82(2), 283-306.

${ }^{428}$ Patricia K. Wood, "Under Which Flag Canadian?": Anti-Americanism and the election of 1891, M.A. (Kingston, ON: Queen's University, 1991), 21.

${ }^{429}$ Ibid., 101. 
along with being anti-American, was also full of republican-themed messages. The campaign of "The Old Leader, The Old Flag and The Old Policy" created a rival discourse to continentalism that was equally well grounded in civic republican ideas about political virtue and community. Leaving the internal politics of the Liberal Party aside as well as those events after May 1891 until the next chapter, the focus on the Conservative campaign will help to unravel the effect of the election on the viability of the continentalist option in Ontario.

Of primary importance to this interpretation is the rhetoric of war used by the Conservatives when discussing the campaign. Wood's thesis concludes, based on speeches published in the Empire and Citizen, that Macdonald thought of the 1891 campaign as a war. ${ }^{430}$ This is not surprising. Warfare was a common metaphor for a myriad of social activities that were gendered masculine; elections were no exception. ${ }^{431}$ What made the Macdonald loyalty campaign of 1891 unique was not that it used the war frame, but that it contorted that frame into a binary of Canadian vs. un-Canadian, citizen vs. traitor, thereby adopting a militaristic frame that simulated a winner-take-all civil war, rather than a more tolerant divide between loyal Liberals and loyal Conservatives.

Foucault declared that

...politics is the continuation of war by other means...[the role of which] is perpetually to use a sort of silent war to reinscribe that relationship of force, and to reinscribe it in institutions, economic inequalities, language and even the bodies of individuals... within this 'civil peace,' these political struggles, these clashes over or with power, these

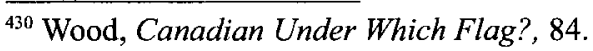

${ }^{431}$ Mark Moss, Manliness and Militarism: Educating young boys in Ontario for war. (Don Mills, ON: Oxford UP, 2001), 26.
} 
modifications of relations of force... in a political system, all these things must be interpreted as war." 432

Thus, the declaration of war made so prevalently in many of the political posters produced for the Conservative campaign must be understood as exactly that: a call to arms, a narrowing of the boundaries of community, a summoning of civic virtue to the acts of securing a kind of military honour. In short, the Tory approach to the 1891 election constituted an appeal to a classical republican enterprise, which according to Honohan, stressed the fragility of freedom "...guaranteed by the rule of law..." and the importance of citizen virtues in sustaining the tightly bound community. ${ }^{433}$ The republican ideal of the Greco-Roman world was the phalanx or the legion: the wellregimented group of soldiers aiming at a common objective, securing glory on the field of battle. These classical traditions still held a certain positive allure in nineteenth century politics and were easily exploited by politicians like Macdonald. In aligning himself with the civic republican tradition, Macdonald was able to tap into existing political beliefs in order to ensure the "sympathetic" reception of his campaign material by the electorate.

This civil war frame is central to Macdonald's loyalty discourse. In the published speech of 7 February 1891 that acted as the basic platform document of the Conservative Party, Macdonald set up the so called loyalty cry as a call to arms to protect the political community. In effect, Macdonald and the Tories had constructed a rival political ideology to counter the socio-political values embedded in the continental policy of the Liberal Party. Macdonald stated that the Liberal Policy of Unrestricted Reciprocity would “...

${ }^{432}$ Michel Foucault, Society Must be Defended: Lectures at the College de France 1975-1976, (New York: Picador, 2003), 16.

${ }^{433}$ Honohan, 15. 
inevitably result in the annexation of the Dominion to the United States" and that it was the "...first step in the direction of political union."

For a century and a half this country has grown and flourished under the protecting aegis of the British crown...These pioneers were speedily recruited by the advent of a loyal band of British subjects, who gave up everything men most prized, and were content to begin life anew in the wilderness rather than forgo allegiance to their sovereign...to you Canadians I appeal, and I ask you what have you to gain by surrendering that which your fathers hold so dear?...A British subject I was born - a British subject I will die. With my utmost effort, with my last breath, will I oppose the "veiled treason" which attempts by sordid means and mercenary proffers to lure our people from their allegiance. ${ }^{435}$

The deployment of terms like "mercenary" and "treason" spoke of war and the enemies both from without and within that must be guarded against. In short, the campaign was to be understood as a fight for the survival of the political community.

At the Toronto Academy of Music ten days later, Sir John was set to lift the veil from the treasonous cabal. The discovery of the infamous Farrer pamphlet by a Conservative agent, a pamphlet written for an American audience that indicated commercial union as the first step to annexation, implicated the Globe's editor and by association Sir Richard Cartwright, the leading Ontario Liberal, and Laurier, in an annexationist plot. This allowed Macdonald to articulate his loyalty cry in an even more persuasive fashion. ${ }^{436}$

But it was the Conservative posters displayed during the campaign that in some ways brought home the case more clearly.

\footnotetext{
${ }^{434}$ John A. Macdonald, Address to the Canadian People, February 7, 1891 [microform], 4.

${ }^{435}$ Carrigan, 31-32.

${ }^{436}$ Cumming, Secret Craft, 8-10
} 


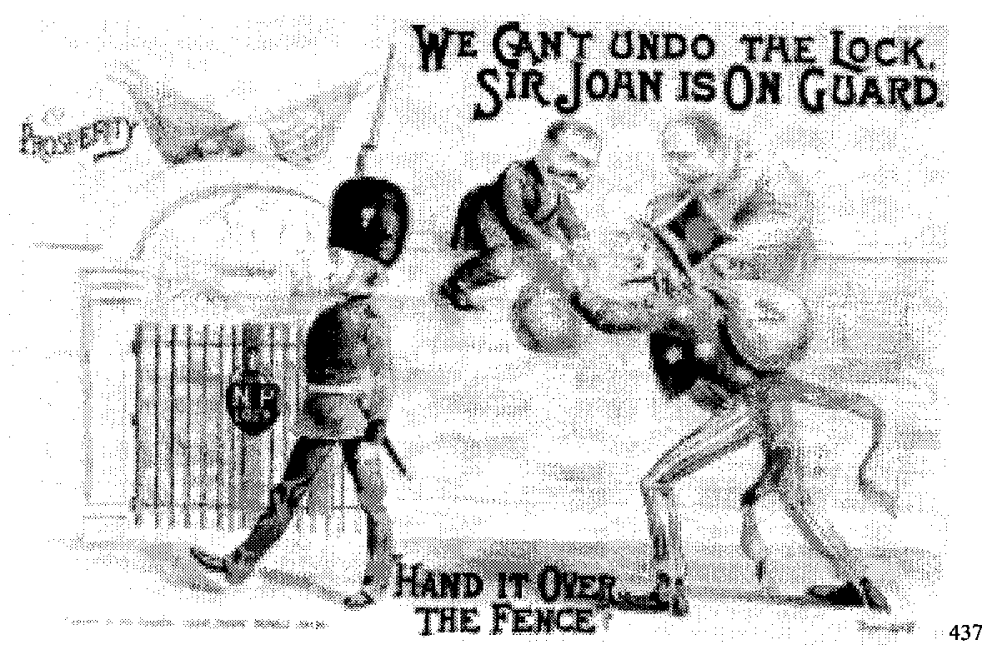

The image above with the "N.P. lock" shows the National Policy not only performing an economic role but a military one, keeping invaders out. Macdonald stands on guard outside the fence in full British military garb protecting the country presumably lying on the other side. This poster represents the militaristic message of "protecting" the community against those who would destroy it from within, or, in the case of Uncle Sam, who hover menacingly outside it.

Another poster clearly highlighted the tenuousness of Canadian freedom in the Tory mind.

${ }^{437}$ We Can't Undo the Lock, Sir John is On Guard, [Election Poster], (The Industrial League, 1891) MG26A Vol. 612, Library and Archives Canada, Ottawa, ON. 


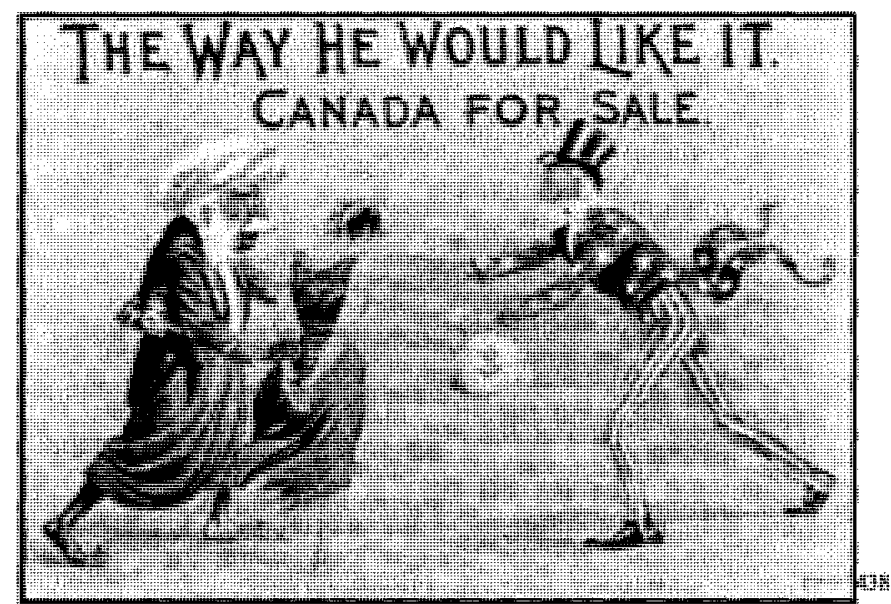

Here we have an arabized Richard Cartwright selling away Miss Canada into slavery with the United States. Along with playing upon racial stereotypes regarding the sinister nature of Arabs to denote danger the poster deploys the imperialist racial discourse, bringing into question the whiteness of the Liberal Party. The deployment of this discourse at home casts Cartwright as the enemy within who would enslave the country. Such imagery played upon the classical republican polarity of freedom and slavery discussed above.

Finally, the threat of continentalism was portrayed not only as foreign, but also inhuman. The following poster provides a clear example.

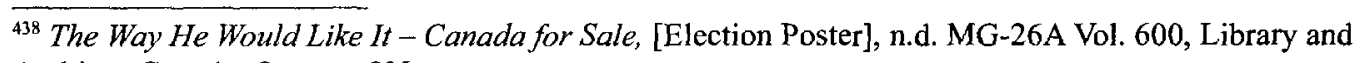
Archives Canada, Ottawa, ON. 


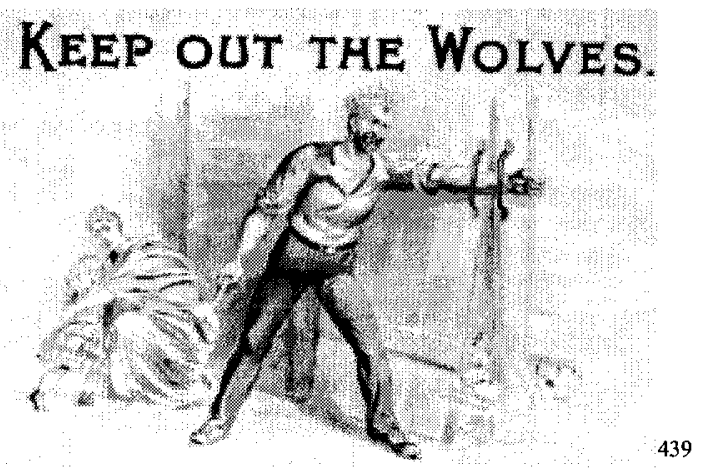

Here a mother and child cower as the sturdy, manly industrial labourer works to keep the door shut from the wolves symbolizing danger to his family, as well as poverty. Animals significantly could not be reasoned with, especially not vicious wild animals like wolves, among the most feared wild animals since the nineteenth century. As such, they had to be dealt with decisively.

Macdonald's posters were not all negative, but sometimes drew on notions of community and portrayed Macdonald as the founder and guardian of the nation. The most famous example has already been mentioned:

${ }^{439}$ Keep out the wolves. [election poster], (The Industrial League, 1891), MG-26 A Vol. 609, Library and Archives Canada, Ottawa, ON. 


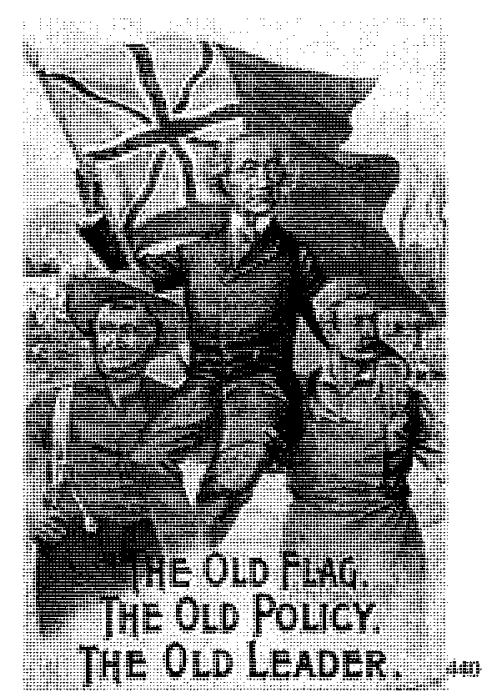

The above poster shows both labourers and farmers holding up Macdonald who, by holding the flag, embodies the nation. In the left background the idealized image of the farm is found while in the right background a busy factory and locomotive can be seen. Images of prosperity and production as well as pastoral idealism are fused in this vision of a happily welded Canadian society.

Thus, the Tory defence of the National Policy attempted to draw on the same iconography of rural stability, community, slavery and freedom, and civic participation that was so central to the legitimization of the continentalist cause. Macdonald's campaign posters, as is well documented by McKirdy and Wood, worked to stigmatize the Liberals as non-white traitors annexing the country to the United States. ${ }^{441}$ Richard Cartwright, for instance, was portrayed as selling away the nation to the United States. ${ }^{442}$ In short, the Liberals and by extension their supporters were portrayed as effeminate,

${ }^{40}$ The Old Flag, The Old Policy, The Old Leader, [Election Poster], (The Industrial League, 1891), Library and Archives Canada, Ottawa, ON.

${ }^{441}$ McKirdy, 149.

${ }^{442}$ McKirdy. 148. 
racially inferior and, sometimes, as inhuman. By exciting existing social anxieties and existing notions of exclusion present among Canadians of British descent, the campaign reinforced a civic republican tradition with the Conservative cast in the role of the defenders of the nation. ${ }^{443}$ However, within the broader context of the campaign as a war, the posters take on a new power and slightly different meaning as a call to arms for all members of the community in order to defend it in a war of ballots, rather than bullets.

The belligerent framework of the 1891 election is important for other reasons. Benedict Anderson's classic work Imagined Communities reminds us that nations are moulded from processes of remembering and forgetting; of inclusion and exclusion based on perceived difference. ${ }^{444}$ As has been previously discussed, civic-republican definitions of community and nation rely upon the same processes of inclusion and exclusion based upon categories like civic virtue and through the promotion of certain national "values". ${ }^{445}$ In short, it requires the stigmatization of certain beliefs and ideas and the promotion of others in order to maintain allegiance to the state and nation as ideal. In order for exclusion to occur, there must be a situation which destabilizes the existing social order that makes a particular belief or idea and those who hold it the potential object of discipline. In short, it requires social trauma.

In Trauma and the Memory of Politics, Jenny Edkins, drawing at least in part on Foucault, writes that the modern state is produced and sustained by a process of "organized violence." exclusion [in which the state] can change the definition of who precisely will be excluded

\footnotetext{
${ }^{443}$ Wood, Defining "Canadian", 66.

${ }^{444}$ See Benedict Anderson, Imagined Communities, (New York: Verso, 2006), 197-206 \& 83-111.

${ }^{445}$ Ibid., 88-91.

${ }^{446}$ Jenny Edkins, Trauma and the memory of politics, (Cambridge: Cambridge UP, 2003), 6.
} 
at any time." ${ }^{447}$ She goes on to say that "exclusion does not always entail expulsion: there is also the excluded 'enemy within'."448 It follows that "political communities...survive in part through the scripting of...events as emergencies, or even, indeed, as traumatic." ${ }^{449}$ The drift of Edkins' analysis is clear. Macdonald's goal - to frame the election in stark terms of loyalty - was to script the campaign as traumatic in the form of a civil war. The vitriolic nature of the campaign makes sense when we view the campaign as a manufactured trauma for short-sighted political expediency intent on excluding certain views and consequently certain individuals from the nation. Given the rhetoric of the campaign and the predisposition to militarism in Canadian society, it is highly likely that Macdonald's tactic spoke clearly and effectively to those who identified themselves as members of the Canadian nation, continentalist or otherwise.

The Liberal response throughout the campaign became a defensive one. In an article entitled "True Loyalty" in the Globe, the main Liberal mouthpiece of the partisan press, the Liberal response was spelled out:

There is but a fragment of our people either Conservative or Reformer who do not love the British connection...I trust and hope that my children and my grandchildren will who have also been born British subjects, will live their lives as British subjects and as British subjects die...I rejoice that there is so much loyalty among the people...I am quite sure that the Reformers will not be Yankified by Unrestricted Reciprocity, and I hope that the Conservatives will not be Yankified by any means either. ${ }^{450}$

For the event to truly be traumatic, and thereby, for it to truly open the way for the exclusion of the 'enemy within' it had to come from the entire state system, not merely

\footnotetext{
${ }^{447}$ Ibid.

${ }^{448}$ Ibid.

${ }^{449}$ Ibid., 5.

${ }^{450}$ Globe, 19 Feb 1891, 2-3.
} 
the partisan machine of the governing party. Indicating that disloyalty existed not only amongst the Liberal Party, but also equally amongst the Conservative Party was a poor strategy as it added more weight to the Conservative claim by indicating that the enemies of Canada were found in all parties. The purging of the disloyal element then became a national priority rather than a party one. The other effect was to force those within the Liberal Party committed to the policy of Unrestricted Reciprocity to reconcile their beliefs with their notions of citizenship.

Exacerbating this concern about the loyalty of Unrestricted Reciprocity were the actions of Edward Blake, former leader of the Liberal Party and former premier of Ontario. Blake opted to decline a Liberal nomination for the election of 1891 , in part because of the adoption of the policy of Unrestricted Reciprocity. Blake's opinion carried a great deal of weight within the party, particularly within the Ontario wing and unfortunately for the overall image of the Liberal campaign, Blake's spurning of the nomination did not come silently. Always opinionated and politically undisciplined, Blake could not pass up the opportunity to moralize on the new Liberal policy of Unrestricted Reciprocity. In an open letter to his former constituency of West-Durham, Blake argued that Unrestricted Reciprocity was a euphemism for commercial union, thereby helping the Conservatives to trigger the anxiety over loyalty that permeated the election campaign of 1891 . For Blake, this meant not only the surrender of control over the tariff, but also represented the first step towards the annexation of Canada to the United States. ${ }^{451}$ Blake, though more moderate than Macdonald, was emphatic: "The

$\overline{451}$ Edward Blake, Letter of the Hon. Edward Blake to the West Durham Reform Convention [microform] : to which is appended correspondence as to the Inverary meeting, (Toronto : Budget Print. and Pub. Co., 1891)5-6. 
treaty once made, the vantage ground it gave would naturally be used for the accomplishment of its ulterior purpose, [annexation]. ${ }^{{ }^{4} 452}$ Blake was careful not to accuse any members of his own party of being annexationists, but the unavoidable implication of his outburst was to play into the hands of the Tories and their framing of the 1891 election as a do-or-die question of loyalty.

Blake's letter, however, would not see the light of day until after the campaign. Rumours swirled throughout the campaign about the infamous West-Durham letter, but the actual copy was not released until after the election, largely as a result of persuasive pleas by Laurier and Cartwright that Blake not publish it before the votes were cast. ${ }^{453}$

Nonetheless, the Liberals lost the election of 1891 and were left to reflect on the wisdom of their continentalist stand. In personal correspondence received by Laurier after the campaign, party sentiment clearly tended to construe the party's platform as perfectly in accordance with "loyalty" or, at least as having survived the implication of treason. Cartwright, noting that the Liberals had won a majority of central Canadian seats, attributed the loss to recalcitrant Tory opinion in the East and West, "the shreds and patches of Confederation." The reassurance that the party had taken the right path came largely from the American reciprocity and annexation movement. The annexationist editor of the New York Sun and former Canadian politician Glen wrote to Laurier that "The loyalty cry has done its worst," and that "...the country is [simply] in need of further education." ${ }^{454}$ Erastus Wiman, the Canadian born developer of Manhattan Island,

\footnotetext{
${ }^{452}$ Ibid., 7.

${ }^{453}$ Richard Cartwright, Reminiscences, (Toronto: William Briggs, 1912), 297.

${ }^{454}$ Glen to Laurier, 6 March 1891, Letter, Sir Wilfrid Laurier Papers, LAC, Ottawa, Microfilm C-738, $1639-$ 1640 .
} 
reiterated Glen's optimism, stating that “...sentiment [for unrestricted reciprocity] is growing all the time."455

Meanwhile, letters from loyal Ontario Liberals aimed at justifying the policy of Unrestricted Reciprocity along loyalist grounds. A letter of 13 March 1891 stated that support of Unrestricted Reciprocity was "perfectly loyal". ${ }^{456}$ Those in south-western Ontario also seemed to interpret the loyalty cry similarly where according to one correspondent, "Unrestricted Reciprocity is the only answer to annexation...[and] I am...too much a Canadian to accept [annexation]." ${ }^{, 457}$

Clearly, then, those who had endured the campaign in Ontario had absorbed the necessity of justifying their political beliefs along the grounds of loyalty to the Canadian project. The language of loyalty had become a significant portion of the political rhetoric during the campaign and consequently began to re-shape the discourse around continentalism.

While both Conservatives and Liberals had provided the rhetoric that emphasized loyalty as a political justification for policies and ideas, there still remained a strong disconnect between the loyalty to the British connection as envisioned by Blake and Macdonald and the loyalty of many "true Grit" Ontarians. This continentalist-based loyalty continued to reflect a strongly continentalist vision of Canada as a way of ensuring its national independence and strength. Thus, while Unrestricted Reciprocity, in its refusal to adopt the more radical republican rhetoric of the agrarian movement, sat beaten and bloodied after the election, continentalism had not been wholly defeated.

\footnotetext{
455 Wiman to Laurier, [Letter] 13 March 1891, Ibid., 1644-1645.

${ }^{456}$ J.A.S. Fisher to Laurier 13 March 1891, Ibid., 1666.

${ }^{457}$ Casel to Laurier 12 March 1891, Ibid., 1675-1678.
} 
Instead, as the campaign ended, it was clear that the Conservatives had lost ground in Ontario to the Liberals. The survivors on both sides of the floor returned to Ottawa for another legislative session with nothing seeming to have changed. Yet, the seeming return to normalcy following the election was to be short lived. A new national trauma was on the horizon: another, albeit unintended, result of John A. Macdonald's influence on Canadian politics. 


\section{Chapter 5: The End of the Continental Vision}

The St. George's Society of Toronto, founded in the later half of the nineteenth century, was one of the more apolitical middle-class societies in nineteenth century Canada. Though named after the patron saint of England, its mission was selfconsciously non-partisan: to provide medical care and charitable services to the less fortunate of Toronto. Party politics were not to be discussed and membership was not to be refused on such grounds either. Spared the anti-catholic mission of the Orange Lodges or the moral authoritarianism of temperance societies, it provided the perfect venue for the community involvement of a "liberal of the old school" committed to principles like self-reliance and freedom of speech - a liberal like Goldwin Smith.

Smith's involvement with the Society began in June of 1879 when he became a member for life. In The Political Destiny of Canada, written and published a year earlier, the self-appointed public intellectual on Canadian politics had argued in favour of eventual political union between the United States and Canada. Smith's annexationist views were well known to the Society. ${ }^{458}$ In 1881 , Smith was appointed an honourary member and, despite a few objections regarding his political views which were quickly ruled out of order, Smith's status was upgraded. ${ }^{459}$ Smith went on to be elected an officer of the society and in 1889 made an unsuccessful bid for President. ${ }^{460}$

\footnotetext{
458 Goldwin Smith. The Saint George's Society and Goldwin Smith [microfilm], (S.I: s.n., 1896?), 2. ${ }^{459}$ Ibid, 2.

${ }^{460}$ Ibid, $2-3$.
} 
After the election of 1891, the election charged by Macdonald's now infamous loyalty cry, things changed for Goldwin Smith. Smith complained in a letter written sometime after his association with the Society had ended that he was the subject of personal attacks by other Society members. ${ }^{461}$ The real trouble came in January of 1893 after Smith spoke at a meeting for the Continental Union Association. Following his speech, J. Castell Hopkins, another member of the Society and outspoken opponent of continentalism, accused Smith of treason and declared that loyal Englishmen must get rid of traitors like Smith. ${ }^{462}$ Unlike the grumbling of 1881, this motion to have Goldwin Smith removed as a member of the Society went forward, declaring the Society's displeasure with Smith's views and stating that those views injured the Dominion, Great Britain and deprived Canadians of their birthright. ${ }^{463}$ For Srnith, the writing was on the wall. The sheer antipathy of the Society towards him and now the official censure pushed Smith to resign in September of 1893.

Despite the consistency of Goldwin Smith's advocacy of political union and his consistent imperialism, his views on Canada's future, though unpopular, were acceptable for a society like the St. George's Society in the 1880 s. However, by the 1890 s simply to hold the opinion of annexationism had become tantamount to treason in middle class urban Canada and, as such, grounds on which to exclude someone from the political community. Torontonians' boundaries of acceptable citizenry appeared to have shifted.

Traditionally, this shift in Smith's acceptability in good Toronto society has been interpreted by historians as the result of the Conservative loyalty cry of the election in

${ }^{461}$ Ibid., 3.

${ }^{462}$ Ibid, 5 .

${ }^{463}$ Ibid, 6-7. 
1891 and the work of the Liberal-Conservative Party, along with certain "loyal" Liberal

politicians like Edward Blake and Oliver Mowat. It was their actions, historians hold, that

forced the end of the tolerant acceptance of "veiled treason" or, stated more

diplomatically, the "continental policy" of the Liberal party. ${ }^{464}$ Surely, there is some truth

in this view. Macdonald's decision to fight the election on the loyalty issue set the stage

for the emergence and entrenchment of the new politics of loyalty, which placed

continentalism beyond the scope of acceptable counter-conduct. No doubt, Macdonald's

June 1891 death served to amplify the sanctity of his British definition of Canadian

citizenship. However, the above works cannot account for the decline of continentalism

from 1891-1896 in Ontario society. The reader of these histories gets the impression that

loyalty seemed to have magically trickled down from the party to the other parts of

society. ${ }^{465}$ Annexationism and, more broadly, the continental vision "... broke itself on

the rugged loyalty of most Canadians..." D.F. Warner argued in $1960 .{ }^{466}$ Patricia K.

Wood, the most recent scholar to comment on the 1891 election, writes that "Macdonald's

congratulatory telegrams and letters reflected how deeply the sympathetic electorate had

absorbed the Conservatives' images of Canada and the Liberals during the election." ${ }^{467}$

\footnotetext{
${ }^{464}$ See R.C. Brown, Canada's National Policy, (Princeton: Princeton UP, 1964), 242-280; D.F. Warner, The Idea of Continental Union, (Tennesee: University of Kentucky Press, 1960), 201-245; P.B. Waite, Canada 1874-1896: Arduous Destiny, (Toronto: McClellan-Stewart, 1971), 229-250; J. Murray Beck, Pendulum of Power, (Scarborough, ON: Prentice Hall, 1968), 57-85; Patricia K. Wood, Under Which Flag Canadian?: Anti-Americanism and the Election of 1891, M.A., History, Queen's University, 1991 and "Defining "Canadian": Anti-Americanism and Identity in Sir John A. Mcdonald's Nationalism" Journal of Canadian Studies, 2001 36(2), 49-69; Jack Granatstein, Yankee Go Home: Canadians and Anti-Americanism, (Toronto: Harper Collins, 1996); K.A. McKirdy, "The Loyalty Issue in the 1891 Federal Election Campaign, And An Ironic Footnote," Ontario History, 1963 55(3) , 143-153.

${ }^{465}$ Regarding loyalism, the reader may be puzzled at the absence of Carl Berger's work The Sense of Power from this chapter. The reason for this is that Berger's focus is on unpacking of the imperialist/loyalist credo through a survey of the thought of five individuals who embodied said thought. The focus of this paper is elsewhere and though the likes of Colonel Denison enter the narrative on occasion it is merely in passing. As such, for the sake of length there is no in depth deiscussion of Berger's book at this juncture.

${ }^{466}$ Warner, 239.

${ }^{467}$ Wood, Under Which Flag Canadian?, 101.
} 
Another author concludes that Canadians "desperately wanted to remain British." 468 The election had succeeded in "working the Canadian people into a heat of loyalty sentiment," a heat that Smith himself soon encountered at the St. George Society. ${ }^{469}$

However, following the 1891 campaign, some of these same authors have identified an increase in annexationism and free trade sentiments among Ontario farmers, suggesting that things were perhaps a little more complex than the straightforward explanations above would suggest. ${ }^{470}$ Furthermore, it is evident from Goldwin Smith's experience that the loyalty cry had not reached its full effect until after 1893 . Finally, the telegrams and letters of congratulation to Macdonald that Wood cites as proof of her argument are not much different in intensity than those received by Laurier encouraging him to press on with Unrestricted Reciprocity to save a Canada "drunk on protection" from the "blue devils" encouraging Canada to "take another drink." ${ }^{" 471}$ Clearly, loyalism had not become rigidly exclusive as soon as these authors imagined, nor had continentalism declined much as a political movement before 1893 .

As such, this chapter will bring this thesis towards its conclusion by reinterpreting the events following the election of 1891 , not as merely residual to the conflict between the Macdonaldian vision of Canada and the continental one, but rather as central to the ultimate transformation of continentalism, from a legitimate counter-conduct located within the spectrum of acceptable political opinion, to one antithetical to membership within the Canadian polis, and, as such, outside the civic republican tradition from which

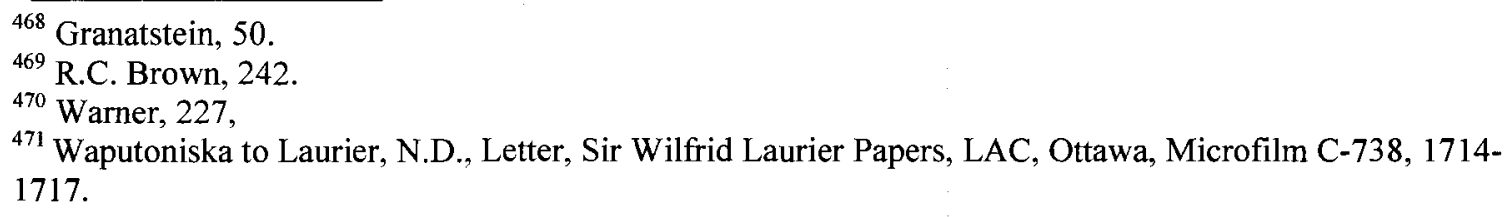


it originally garnered its strength. While the election of 1891 allowed Macdonald and the Conservatives to appropriate the language of civic republicanism, especially that of community and virtue, to the ends of securing their political project, neither this appropriation nor the resulting election victory is sufficient cause to explain the delegitimization of continentalism as a political option. Tracing such cause and effect will take this chapter across varied landscapes from the political effects of Macdonald's death and the spectacles accompanying it, to the politics of tariffs, to meetings promoting political union and to the first ever Liberal Party convention in 1893. It is a whirlwind tour in some respects, as many of the events touched upon are worthy of a closer and more focused examination in order to shed new light on politics in the 1890 s. However, our objective here is a history of continentalism, and, thus, our focus will be on understanding these events only in their effect upon the shape and momentum of the movement.

\section{The Death of a Prime Minister}

History is often the product of accident as much as intent. While much of what led to the decline of continentalism was conscious and intended, there were other serendipitous factors which had a profound effect upon the shape of the continentalist movement. The death of Sir John A. Macdonald in June 1891 was one such event.

Only months after his narrow victory over the Liberal Party and the "veiled treason" of unrestricted reciprocity, "Old Tomorrow", father of confederation, first prime minister of Canada, ran out of days. On 29 May 1891, while recovering from a cold and a 
small stroke, Macdonald was stricken with a massive stroke paralysing the right side of his body and leaving him incapable of speech. ${ }^{472}$ The House Leader, Hector Langevin, upon receiving the news reported it to the Opposition Leader, Wilfrid Laurier, and the House immediately and willingly adjourned. Laurier described the effect of the news on the debate then underway: "the surging waves of angry discussion were at once hushed, and every one, friend and foe, realized that this time for a certainty the angel of death had touched him had appeared and had crossed the threshold of his home." ${ }^{943}$ Just over a week later, late in the evening of Saturday 6 June 1891, Macdonald died.

The response to Macdonald's death was as surprising as it was overwhelming. Newspapers, Liberal and Conservative alike, dispensed with the partisan snipping to print glowing eulogies of the late Prime Minister. ${ }^{474}$ The House resumed business on Monday, 8 June 1891 to discuss the death of Sir John. The Speaker had taken the liberty of putting up the symbol of mourning - black crepe - in the House as a tribute to Macdonald. ${ }^{475}$ The symbolic implication was that the state and nation had suffered a great loss. Langevin opened the session with what was to be a glowing and lengthy tribute. However, after only a few minutes he declared before the House: "I cannot proceed further," and moved a motion to have Macdonald's remains publicly interred, adding "that this House will concur in giving to the ceremony a fitting degree of solemnity and importance."\$476 Laurier spoke next. Though he was careful to point out that "we on this side of the House... did not believe in his policy, nor in his methods of government," Laurier also

\footnotetext{
${ }^{472}$ P.B. Waite, John A. Macdonald: His Life and World, (Toronto: McGraw-Hill-Ryerson, 1979), 213.

${ }^{473}$ Debates of the House of Commons, 883

${ }^{474}$ P.B. Waite, John A. Macdonald: His Life and World, 213.

${ }^{475}$ Debates of the House of Commons, 883

476 Ibid.
} 
conceded that the death of Macdonald was "in every respect a great National loss, for he who is no more was, in many respects, Canada's most illustrious son, and in every sense Canada's foremost citizen and statesman." ${ }^{477}$ Laurier had metaphorically chosen to wrap Macdonald's body in the cloak of national founder. As Iseult Honohan reminds us in Civic Republicanism, republics "...require a founder or law giver to establish their basic institutions." ${ }^{\text {778 }}$ Macdonald had helped to create and had defended the National Policy for 12 years. With his death and the subsequent spectacles surrounding it, Macdonald was remade by the Conservatives and their Liberal opponents alike into the Founder of the Nation. As such, the relationship between a citizen and the symbol of Macdonald's corpse became one of the primary factors in determining a citizen's membership in the Canadian polis.

Evidence of this can be seen in the behaviour of Ontario members of Canadian society. Ontarians went out of there way to express their condolences to Lady Macdonald. Thousands went to pay tribute to Macdonald's body as it lay in state in the House of Commons and many more made the trip up to Parliament Hill to watch his funeral procession depart. ${ }^{479}$ In St. Thomas, for instance, on 11 June 1891 citizens in the community held a public meeting at City Hall to coincide with the exact time of John A. Macdonald's funeral in Kingston. The motion unanimously passed at the meeting spoke of "...the great debt of gratitude we owe to him for the valuable service he rendered to his beloved Canada in the welding together politically of the scattered provinces of British North America into one grand Dominion embracing within its boundary nearly $1 / 2$ of the

\footnotetext{
477 Ibid.

${ }^{478}$ Honohan, 5.

${ }^{479}$ P.B. Waite, John A. Macdonald: His Life and World, 213.
} 
North American continent.."480 Similar resolutions were passed and forwarded on by the City of Toronto, the County of York, the City of Hamilton, the Wellington County Council, and numerous other governmental and professional organizations and lobby groups. The grieving spread across the Atlantic. A special commemorative service was held for Macdonald at Westminster Abbey in London, symbolically reinforcing the invisible link between Great Britain and her Dominion. While one could argue that such an outpouring of sorrow was a pro forma matter, one could also detect subtle shifts involved in the rhetoric, shifts that touched upon and redefined core national values. According to the London Advertiser which formerly supported commercial union, John A. Macdonald death was “.... national calamity..." since Macdonald “...was one with the people in all their interests." The paper went on to declare that Macdonald's legacy could be seen in the most recent election results as "Canada has declared against a policy of annexation." ${ }^{481}$ The Sratford Beacon gave a special report from Ottawa, which transformed the death into a melodrama of national proportions:

Toll, toll, toll went the huge bells at the City Hall last night at 10:30. All Ottawa knew at once that the unparalleled struggle at Ernscliffe was ended - Sir John Macdonald was dead...In clubs, hotels and on the street men stopped with bated breath...Sir John... was more than the Leader of the government, the premier of a great Confederation... he was regarded as a friend. ${ }^{482}$

In the Ottawa Citizen, Macdonald was referred to as "the chief state oracle." these references to Madonald as national founder and "oracle" tended to create a sense of

\footnotetext{
${ }^{480}$ Public Meeting of Citizens at St. Thomas City Hall to Lady Macdonald [letter], 11 June 1891, John A. Macdonald Fonds, vol. 560, Library and Archives Canada, Ottawa, ON.

${ }^{481}$ The London Advertiser, August 8, 1891.

${ }^{482}$ Stratford Beacon, 11 June 1891.

${ }^{483}$ Empire, 8 June 1891
} 
cohesion between the state and the nation. Macdonald governed, but he did so as a "friend" to the nation who had lost him. As such, the nation was called forth by such rhetoric to reinforce the state structure Macdonald had founded. Such a call did not bode well for the continentalist cause, which criticized Macdonald mercilessly.

The rhetoric that used Macdonald as the bond between the nation and the state was further laden with fables telling of Macdonald's civic virtue. The Perth Home Journal told heroic stories of Macdonald's commitment to his duty as P.M. The paper reported on Macdonald's urging at his first collapse for John Thompson, minister of justice, to leave him and attend to his scheduled appointment with the Governor General. ${ }^{484}$ In the pages of the Toronto Empire, columns printed with thick black lines of mourning persisted in the paper for days after Macdonald's death. This Conservative organ declared that Macdonald had "built up the Dominion, well may he be called the father of Canada." 485 A few days later, the eulogy was even more flattering:

...friends and opponents...all agree...that but for him it [confederation] would never have been an accomplished fact and that only for his patriotic efforts...communication both by water and rail with the sea board, [was established]. ${ }^{486}$

The rhetoric of the Empire made it sound as if Sir John had constructed the technological edifice of Confederation with his own hands, rather than the exploited labour of Irish and east Asian immigrant workers. The representation of Macdonald as the patriarch of Canada served to create a symbolic bond between the governmental aspirations of the state and the aspirations of the Canadian nation. As such, it encouraged those who saw

\footnotetext{
484 The Farmers Advocate and Home Journal, 18 June 1891.

${ }^{485}$ Empire, 6 June 1891.

${ }^{486}$ Empire, 8 June 1891.
} 
themselves as Canadian to endorse Macdonald and what he stood for. To be continentalist of any stripe was, by implication, to be against the Canadian project as a whole.

The growth of positive characterization of Macdonald following his death may, from a twenty-first century perspective, seem somewhat familiar and, yet, also foreign. As Pat Jalkand has argued in Death in the Victorian Family, Victorian sensibilities regarding death required the removal of ugliness from death scenes. ${ }^{487}$ This included crafting a memory of the deceased which was positive and soothing. ${ }^{488}$ As a result, "only in the later months of the grieving process did the bereaved usually reassess their relationship with the deceased, considering the negative as well as the positive aspects in a more balanced way." ${ }^{949}$ Considering not only that Macdonald had died, but had died shortly after "defending" Canada from an imagined and rapacious southern neighbour in an election campaign, it is not surprising that views of Macdonald became overwhelmingly positive in the popular press and in other official and semi-official channels. In dying so soon after taking the role of defender of the nation, Macdonald had become the equivalent for many of national founder. As such, criticisms of the National Policy and the promotion of continentalism found themselves relegated to the shadows of the national discourse; pushed, as it were, to the extreme edge of political acceptability.

Furthermore, as Catherine Verdery points out in The Political Lives of Dead Bodies, "a body's materiality can be critical to its symbolic efficacy: unlike notions such as "patriotism" or civil society, for instance, a corpse can be moved around, displayed and

\footnotetext{
${ }^{487}$ Pat Jalkand, Death in the Victorian Family, (London: Oxford University Press, 1996), 186.

${ }^{488}$ Ibid., 286-288.

${ }^{489}$ Ibid., 288.
} 
strategically located in specific places." 490 She goes on to say that "a dead body is meaningful not in itself, but through culturally established relations to death and through the way a specific dead person's importance is (variously) constructed... [the bodies] of political leaders - have served in many times and places worldwide as symbols of political order," ${ }^{\prime 91}$ and in the case of Canada, as a symbol of an emergent foundational myth for the political community.

In approaching the death, public display and funeral procession of John A. Macdonald from this perspective, it is easy to see the way that space and spectacle were used to create a sense of greatness and an equation of John A. Macdonald with the very notion of Canada and Canadianess. In death, Macdonald had a utility that he lacked in life. The decision to lay Macdonald in state in the House of Commons and allowing the public to enter and view the body " 20 at a time...up to 1200 an hour" with police officers in tow served to build a personal connection between the law-giver/leader as the embodiment of the state and the individual members of the nation. ${ }^{492}$ This conclusion is further reinforced by the large number of individuals who came from outside Ottawa, sometimes "600-700 miles away" to view the body. ${ }^{493}$ The body of Sir John acted as a kind of medium binding the two together through his corporeality. From the Empire further details of the procession are provided. The procession was attended by various dignitaries from federal politicians, to representatives from cities, towns, national societies like the St. George Society, and the Governor General, with requests made to the

\footnotetext{
${ }^{490}$ Katherine Verdery, The Political Lives of Dead Bodies: reburial and postsocialist change, (New York: Columbia University Press, 1999), 27.

${ }^{491}$ Ibid., 28.

${ }^{492}$ Empire, 10 June 1891.

${ }^{493}$ Empire, 11 June 1891.
} 
public for assistance. ${ }^{494}$ The funeral procession left the east gate of Parliament, with symbols of the sovereign authority of the state, the Mace of the Senate and the house of Commons, in tow. It travelled up King Street to Daly Street in Sandy Hill where a funeral service was held. The procession then wound its way back along Cumberland and Rideau to terminate at the Rail Station at which point Macdonald was loaded on a train for final leg of the journey to Kingston, where his "sacred remains" were finally laid to rest. ${ }^{495}$ Every station along the CPR, from Halifax to Vancouver, was draped in black, while Macdonald's train was distinguished only in the addition of purple hangings. ${ }^{496}$ When his corpse arrived at the Kingston station it was greeted by 10,000 people eager to pay their respects. ${ }^{497}$ The colour of mourning coupled with the colour of royalty implied the death of a regal symbol, connected to the whole political community and its institutions. Macdonald, followed by the symbols of Parliamentary authority was sent to his final resting place not as the first among equals, but as the de facto King of the Canadian people almost equal in affection and stature to Queen Victoria. As Verdery reminds us, "burials narrow and bound the community of mourners, excluding persons no longer welcome in the national kin group...[burials] involve reconfiguring human communities according to new standards of inclusion and exclusion." 498 In effect, such symbols of mourning served to show one's qualification as "Canadian." Those who did not ascribe to the act of mourning therefore no longer could be considered part of the nation. This helps us to explain the reversal of the views within the London Advertiser. Thus, on one level

${ }^{494} \mathrm{Op}$. Cit.

${ }^{495}$ Empire, 10 \& 11 June 1891.

${ }^{496}$ Empire, 11 June 1891.

${ }^{497}$ Ibid.

${ }^{498}$ Verdery, 111. 
the death of Sir John and the use of his corpse tended to reinforce the National Policy vision of Canada at the expense of the now "annexationist" and "treasonous" continental options. The last lines of Creighton's sympathetic biography capture this parallelism of Macdonald and the Canadian state: "Beyond the dock lay the harbour [of Kingston] and the islands which masked the end of the lowest of the Great Lakes; and beyond the islands, the St. Lawrence river began the long journey to the sea." ${ }^{499}$ Macdonald was the nation; the nation was Macdonald. It is only in understanding the above that the reaction of the "solitary" eastern Ontario farmer is comprehensible "...who stood at the roadside, and as the train sped by, reverently uncovered his head..."500

The Victorian ethic that required one to avoid speaking ill of the dead made criticisms of Conservative policy difficult in the months following Sir John's death. This ethic helps to account for Laurier's laudatory remarks about Macdonald. What else could be said by an aspiring national leader at such a time? Finally, as all democratic nations imbued with the civic republican tradition need a founding figure, Macdonald as he lived and as he was displayed in death tended to embody this role. It was as if the other fathers of confederation simply melted away into the mists of history.

However, Verdery also reminds us that just because there is a single name and single body does not mean that dead bodies can have only a single meaning. Rather, for some who had supported the continentalist call for commercial union, equating the dead body of Macdonald with the state by its display within the Parliament building could have the symbolic meaning that the Canadian state was disintegrating; that the National Policy

${ }^{499}$ Creighton, John A. Macdonald: The Old Chieftaine, 578.

${ }^{500}$ Empire, 11 June 1891. 
would die along with its creator and promoter, the defacto King of Canada. This interpretation, though much less common, could also be identified. As Grip saw it, Macdonald's death meant the end of something tyrannical and the promise of true freedom:

Like merry monarch of some olden line Whose subjects questioned not his right divine, But just obeyed. ${ }^{501}$

Thus, while on the one hand it tended to shrink the boundaries of nation, it also helped to polarize and further radicalize those who did not subscribe to the official construction of the death's meaning. By their exclusion, their sense of being bonded to the polis was undermined. As Farrer had already stated in his then infamous annexation pamphlet: "Sir John's disappearance from the stage is to be the signal for a movement towards annexation." ${ }^{502}$ Thus, to imply that Macdonald was an autocrat, as Grip clearly does in the above quotation was to place oneself outside the political language of the Canadian nation and to align oneself with Farrer in the push for outright annexation. It is this other interpretation of the prime minister's death, accentuated by the lingering effects of the McKinley Tariff, Blake's West Durham Letter, and the election campaign of 1891 discussed in chapter four, which contributed to the shift from a movement in favour of commercial union to a more radical, though also less popular movement favouring political union. The death of Sir John, by closing off the possibility of formal political debate on the continental option, forced the counter-conduct back to the margins, but this time it was a margin and a counter-conduct that had much more

\footnotetext{
s01 J.W. Bennough, Verse In Grip, N.D. [1891?], John A. Macdonald Fonds, Vol. 506.

${ }^{502}$ Copy, Concluding Paragraph of the Farrer Pamphlet, LAC, John A. Macdonald Fonds.
} 
dangerous implications for the survival of the Canadian state. As such, both the Liberal Party and the Conservative Party worked to discredit and destroy the movement as something antithetical to the newly restructured political language of the Canadian national community. In death, Macdonald thereby enjoyed his second victory in 1891 - at the polls he had undermined the loyalty of continentalism and now from his casket he was able to expel the continentalist creed from the forum of legitimate discourse.

Annexationism as Counter-Conduct, April 1891-March 1892

The Conservative Party took an almost disinterested approach to continentalism following Macdonald's death. This attitude is symbolized most obviously by the choice of Senator John Abbott, a signatory of the 1849 annexation manifesto, to lead the party. In large part, the Conservatives strategy remained predominantly rhetorical. By and large, the Conservatives were content with accusing the Liberals of being annexationists. Despite the partisan tone of their efforts, the continued accusations of the Conservatives had profound implications, which were not lost on John Charlton, a Liberal backbencher and free-trader. In 1893 after a "loyalty cry" was made by a Conservative member in the House of Commons, Charlton responded that: "The implication is that one-half of the population is disloyal." 503

Most historians have concluded that this tactic was successful for the Conservatives. Starting in February 1892, the Conservatives enjoyed a series of byelection victories which widened their majority to 63 seats by 1895 from the 27 it had

\footnotetext{
${ }^{503}$ Government of Canada, Report on Proceeding of the House of Commons, (Ottawa: Queen's Printer, 1893), 738.
} 
been once the ballots had been counted on March 5, 1891..04 It has been assumed that this resurgence was the result of Conservative tactics. However, a careful consideration of the Liberal rhetoric within the pages of The Globe between April 1891 and June 1892 indicates that the loyalty cry was successful in large measure because of the work of Farrer in framing the burgeoning annexationist movement as an understandable result to the unfairness of the National Policy and Conservative corruption. The implication is that the Liberal Party supported a movement for annexation, much as the Globe of the early 1880 s had implied that the party supported smuggling in the early $1880 \mathrm{~s}$, as a legitimate counter-conduct. Annexationism or political union had always been a minority view among continentalists. With the Conservatives comfortably occupying the mantle of the builders of the nation following the death of Macdonald, to be seen to advocate for political union as the Globe did in those early months was a dangerous political move - a move which in this instance failed to pay off.

It remains unclear whether the decision immediately following the election to frame annexationism as counter-conduct was a conscious decision on the part of the Liberal Party. Given the personalities involved, it is likely that the Liberal leadership hoped to undermine the apparent monopoly on loyalty the Conservatives had been claiming following the election. However, this intention was to be transmitted into action at the editorial offices of the Globe, which were largely under the control of an avowed annexationist: Edward Farrer.

\footnotetext{
${ }^{504}$ Beck, 73 \& 68.
} 
As has already been discussed, Farrer was considered by many of his contemporaries to be a journalist par-excellence. ${ }^{505}$ His editorials were subtle and often implied what could not be said, or offered up only one possible solution, thereby inviting the reader to make the final commitment themselves. ${ }^{506}$ In Secret Craft, Cumming contests that Farrer was given too much credit by contemporaries and historians such as O.D. Skelton for creating the annexationist bubble of the $1890 \mathrm{~s}^{507}$ Despite the debate over the real effectiveness of Farrer in "creating" annexationism, one cannot understate the role Farrer's work at The Globe played in legitimizing annexationism as resistance and bringing it into the open, while at the same time alienating those Ontarians who did not favour the National Policy, but did not want to see an end to the Canadian experiment. The effect of doing so from the pages of the leading Liberal newspaper was effectively to place the Liberal Party in solidarity with annexationism, and to encourage the expansion of the movement by those who saw Macdonald's death as the end of the experiment of Confederation.

In article after article, Farrer worked to legitimize annexationism in the face of the loyalty cry. Beginning with attacks on the record of the Conservative government and comparisons between Canada and the United States always showing the sad state of the former, Farrer would then go on to argue, as he did in October 1891, that:

There is something infinitely more sacred then loyalty to any flag, and that is the "riteousness which exalteth a nation," but which, in our case, has almost reached the vanishing point. And how long is the sentiment of loyalty to endure if we are to witness, as in the past, the flight of our

$\overline{{ }^{505} \text { Cumming, Secret Craft, } 23-25 .}$

${ }^{506}$ Carman Cumming, "The Toronto Daily Mail, Edward Farrer and the Question of CanadianAmerican Union," Journal of Canadian Studies, 24(1) 1980, 126.

${ }^{507}$ Ibid. 
children to another land the failure of the country to advance in material growth, the multiplication of not inhabitants but taxes, debt and disgrace? Let the Tory speakers, we pray, give us something more substantial then this perpetual scream, which is all a lie, about our readiness to die in our tracks for the Old Flag. ${ }^{508}$

Farrer goes on to ask how to banish all the ills given that the National Policy has

failed. He concludes by asking "ultra-loyalists" (clearly not referring to the

Conservatives) to find a solution..$^{509}$

From the 8 of October 1891, the Globe writes:

...if a plebiscite were taken tomorrow $2 / 3$ of Newfoundlanders' would vote for annexation to the United States. The Canadian census returns have been duly conned at by the islanders and jeered at by the anti-confederationists...It will be a fortunate thing for Canada if the majority of Newfoundlanders continue in the mind of refusing to join us... What would it profit the Ontario farmer to build railroads, harbours, wharves and lighthouses at every mans door there a la Nova Scotia! At the same time the annexation of Newfoundland to the States would create an awkward state of things for the Maritime provinces. American capital would rush into the development of the vast fishery resources of the colony... [which would necessitate more unnecessary expenditure and tariffs] and all the rest of the Tupperian prescription for loyalty. ${ }^{510}$

Another brief from the same day reminds readers that a motion in favour of annexation passed at Windsor and was "taken word for word from the annexation manifesto of 1849 which bore Mr. Abbott's name." ${ }^{111}$ From the very next day titled "What True Loyalty Means," Farrer reminds the reader that "true loyalty often demanded the overthrow of a government." And at another instant that "it is a curious loyalty that...

\footnotetext{
508 "Let us Have Change", Globe, 2 October, 1891, 2.

${ }^{509}$ Ibid.

${ }^{510}$ Globe, 8 October 1891, 4.

${ }^{511}$ Ibid., 8.

${ }^{512}$ Globe, 9 October, 1891, 5.
} 
run[s] the risk of revolution." ${ }^{513}$ It was clear to Farrer that the Conservative government "...is responsible for the outbreak of a continental union movement in Western

Ontario."514. Farrer would often remind readers that "the material well being and the political contentment of a people are intimately related...[let the Conservatives] abandon as treason... a policy which is depopulating the country and filling sections of it with a longing for organic change: [annexation] ${ }^{, 515}$

In Farrer's editorials and the pages of The Globe, annexation in general was given a new meaning as legitimate or even loyal resistance to Conservative misgovernment and the "disloyal" National Policy. This was particularly true so long as no reciprocity agreement could be reached between the United States and Canada. It certainly seems that the Conservative finance minister, George Foster, was correct when he asserted that “...an unprejudiced person can look through the pages of the Toronto Globe for the last three years, and he will find, in almost every edition, argument, insinuation, open assertion and appeal all with the purpose... of undermining the British connection."516 By persisting in trying to legitimize annexationism as a valid and "loyal" political opinion, Farrer likely made annexationism more attractive for those strongly attracted to the continentalist counter-conduct and highly critical of the National Policy. The other effect was to exacerbate the already polarized state of loyalty politics by creating its own binaries of loyal and disloyal, markedly different from those used by the Conservatives. This was all done in a political climate that was focused on the unifying experience of mourning the Canadian founder, not on debating the meaning and destiny of

${ }^{513}$ Globe, 17 October $1891,8$.

${ }^{514}$ Globe, 23 October 1891, 4

${ }^{515}$ Globe, 26 October, 1891, 4.

${ }^{516}$ Cumming, Secret Craft, 212. 
Canada. Annexationism and continentalism became structured as a movement within the politics of loyalty following the election and as such a counter-conduct aimed at governing Canada through different tactics. Annexationist would replace the tactic of using an independent Canadian state with the American state to govern the socioeconomic actions of Canadians. It was radical in its challenge to the authority of the Canadian state, but also conservative in its desire to be governed in largely the same way. In a tight political community of mourners, such as that which arose out of Sir John's death, those excluded, namely any who did not revere the memory and accomplishments of Sir John, were considered outside the proper bounds of the political community. Thus, while preaching to his true believers, Farrer was in effect ostracizing his own movement from the dominant Canadian political discourse. It was in part this marginalization along with Farrer's silver pen that created a political environment favourable to annexationism: in effect, the political project of marginalizing and eradicating the Canadian state. As was previously mentioned in chapter three and again in chapter four, the approaches and tactics used by those in favour of political union in order to popularize the movement and spread the gospel were identical in most respects to those used by the movement for commercial union. What had changed was the political objective. The new position of continentalism as a political discourse meant it could no longer be seen as a critique of the tactics and strategies of the Conservatives used for the governmentalization of the state. Rather, those in favour of political union in the new world of loyalty politics could now seen to be challenging the governmentalization of the state directly. Farrer had thus markedly raised the stakes of the national debate. In doing so, he obliged the Liberal 
Party to make a decision. Faced with a movement that denied the authority of the Canadian state to govern at a juncture where it desperately needed to be seen as committed to Canada, the Liberal Party moved to eradicate continentalism as a legitimate expression of counter-conduct within the political community, by placing it beyond the boundaries of legitimate political language. Counter-conducts, it must be reiterated, rely on the recognition of the particular conduct or discourse as legitimate, that is within the linguistic boundaries of the polis. As we shall see, the denial of this role to annexationism would render it extra-political, and consequently, unacceptable to all but a marginal, radical minority.

\section{The Liberal Party Responds}

While Farrer's editorials fanned the embers of annexation, Laurier and the rest of the party leadership continued to weigh the political potential of continued adherence to the policy of Unrestricted Reciprocity. The months following the March election until the end of 1891 were, not surprisingly, months of indecision on the part of Laurier.

At first, in an attempt to ensure that the Conservatives would be unable to get reciprocity for themselves, Laurier sent representatives to Washington to block any Conservatives overtures and convince American statesmen that the Liberal party was the sole party of reciprocity. His two most frequent emissaries were John Charlton and Edward Farrer. ${ }^{517}$ But they would often overstep Laurier's instructions, giving the Conservatives plenty of ammunition with which to continue their accusations of Liberal

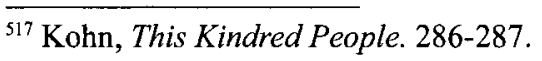


treason..$^{518}$ The delicacy of the situation surrounding the policy of Unrestricted

Reciprocity was well understood by Laurier who had, even prior to the election of 1891 , confided in Edward Blake that he had reservations. In a letter from Blake to Laurier in early 1892 , Blake was happy to remind him that:

At our last interview just before the nomination for the general election, you stopped me in the discussion of this point [surrounding the problems of Unrestricted Reciprocity] by saying I need not argue it further, that you were convinced upon it; and that the party policy must be revisited; and that, from that point of view you dreaded success at the election. ${ }^{519}$

Blake also reported in the same letter that Laurier had written to him in the summer of 1891 reiterating that the policy must be changed once a "favourable occasion could be found." 520 No such occasion seemed to present itself to Laurier in 1891, but the pressure to do something was constant. Laurier was aware of the rising stakes of the Liberal position, a position perceived as semi-formal support of annexationism. In a letter to another Liberal, Laurier commented that "the movement for political union which manifests itself in certain counties is not yet a serious one, but it might very soon become so if a prominent man were to place himself at the head of it." 521

Before the year was out, Laurier would find himself under added pressure from Oliver Mowat. In stern and frank letters written in his dual role as the premier and attorney-general of Ontario to Laurier, Mowat expressed his fear that annexationism was drawing the Liberal Party onto the reefs of destruction.

\footnotetext{
518 Ibid.

${ }^{519}$ Blake to Laurier 23 April 1892, Letter, Sir Wilfrid Laurier Papers, LAC, Ottawa.

${ }^{520}$ Ibid.

${ }^{521}$ Laurier to Gregory, 26 October 1891, Sir Wilfrid Laurier Fonds, Microfilm C-738, 1913
} 
The Globe is creating an annexationist party out of members of the Reform party, and has accomplished more in that direction than I was aware of...I find that at meetings in the rural parts, in even my own constituency, the Globe is being cited to old reformers as going for annexation and that this is bearing fruit amongst them. I presume you disapprove of this and might do something to prevent further harm in that direction...If nothing can be done, an open division in the party is inevitable and its consequence destruction. Whether a strong annexation party can be created from its ruins I do not know, but I should hope not. ${ }^{522}$

It seems Laurier took Mowat's warnings seriously. The Ontario wing of the party was the most deeply rooted portion and, as such, Laurier could little afford to lose control of and standing within it. Laurier wrote back the same day in the affirmative about stemming the tide. On New Year's Eve, Mowat responded with advice to that effect. Along with cleaning up The Globe staff who had apparently become "liveli [sic] annexationists", Mowat suggested checking Cartwright's perceived pairing of loyalty with political union and also "a distinct... and emphatic... [declaration] against political union as a price too great to pay for Unrestricted Reciprocity." 523

As 1892 dawned, it had become clear to Laurier that something had to be done to eradicate or silence annexationism specifically, and continentalism more generally, within the ranks of the Liberal Party. The debate was pushing the party into the realm of political marginalization. From January to March of 1892, Laurier and Mowat contented themselves with reducing Farrer's influence over the Globe. ${ }^{524}$ But what Laurier really needed was the right political occasion to inoculate the party against charges of disloyalty. In April of 1892, the waiting would come to an end.

\footnotetext{
${ }_{522}$ Mowat to Laurier, 26 December 1891, Letter, Sir Wilfrid Laurier Papers, LAC, Ottawa, C-738, 2041

${ }^{523}$ Mowat to Laurier, 31 December 1891, Ibid., C-738, 2042-2043.

${ }^{524}$ Cumming, Secret Craft, 213.
} 
The Attack on Continentalism

On 12 April 1892 Edward Blake, the Liberal leader before Laurier, sent Laurier a brief and somewhat threatening letter. As his West Durham letter of 1891 had illustrated, Blake's missives were not to be taken lightly. In reference to Laurier's own statements regarding the unsuitability of Unrestricted Reciprocity, Blake made the case that the time had come to shift the policy of the Liberal Party towards a more limited version of reciprocity. ${ }^{525}$ Blake was sure to add that refusal to act on this point would lead him to make his views public. ${ }^{526}$ Laurier's response indicated that a change was already in the works and that Blake's input was desired ${ }^{527}$ On the $23^{\text {rd }}$ of April, Blake responded with a detailed outline of how it was to be done.

Blake explained that in a recent meeting between the Conservative Finance Minister Foster and the American government, the Americans had made it clear that their assumptions regarding Unrestricted Reciprocity were that i) Canada would assimilate to the U.S. duties; and ii) that because this meant discrimination against the products of the mother country, Great Britain would never allow it. Realizing this, Blake made the case that this American intransigence made the political waters right for Laurier to change the policy from Unrestricted Reciprocity to one of "...a large and liberal treaty..." which would include natural products as well as a large group of manufactured goods. ${ }^{528}$ Blake's argument was persuasive:

I am strongly of the opinion that every month during which you preserve in the attempt to hold your present false position will render your extrication more difficult...I think that now,

\footnotetext{
${ }^{525}$ Blake to Laurier, 12 April 1892, Letter, Sir Wilfrid Laurier Papers, LAC, Ottawa. 526 Ibid.

${ }^{527}$ Blake to Laurier, 18 April 1892, Ibid., c-738, 2138.

${ }^{528}$ Blake to Laurier, 23 April 1892, Ibid.
} 
when the fortunes of the party are at the lowest ebb, when the elections have gone against you, when yet there is time before the next general election to reform your ranks on new lines, and to familiarize your friends with the new position, now is the time to act. ${ }^{529}$

Blake's prescription for action was not just the announcement of a new policy but also required the active discipline of party opinions and the removal of particular individuals. It is this disciplinary process that has yet to be traced effectively by historians. Furthermore, such tactics aimed at normalizing the behaviours of those belonging to or sympathetic to the Liberal Party shows that it was no 'loyalty cry' or deep seated sense of loyalty alone which drove continentalism to its grave. Rather, as we shall see, it was by the raw and expedient exercise of power by the state and other social organizations, like the St. George Society, legitimized by the rhetorics of loyalty which killed continentalism as a viable counter-conduct within the bounds of an acceptable national political discourse.

When it came to reforming the ranks of the Party, it was not Laurier who made the first move, but rather the eager Sir Oliver Mowat, freshly entitled, who found an opportunity to begin making an example of annexationists. On 22 June 1892 the Meyers affair broke on the front page of the Globe. The incident hinged on letters exchanged between Sir Oliver Mowat and Crown Attorney for Dufferin, Elgin Meyers Q.C., letters that the Globe published. Meyers had written several open letters advocating annexation and was consequently the recipient of stern warning from Mowat to recant. Meyers refused. The Globe, without explicit evidence to the effect came to the conclusion that "it 
is understood, however, that Mr. Meyers will be dismissed from the position which he at present holds under the crown, and to which he was appointed by Sir Oliver Mowat." 530

As leader of the provincial Liberals, Mowat had built up an impressive series of electoral victories over the provincial Conservatives, a political base he had used to score judicial victories against Macdonald and the Dominion government over the nature of the Canadian constitution. Mowat was also an expert at patronage, using a much smaller purse than Macdonald's to build Ontario up as a Liberal party stronghold. ${ }^{531}$ The Q.C. designation of which Meyers was a holder was a typical provincial patronage plum in the legal profession as was his posting to the position of crown attorney. Mowat could not remove the Q.C. designation once bestowed, but the job as crown attorney existed at his discretion. In dismissing Meyers, Mowat's message was crystal clear: Liberals who advocated annexation would be cut off from the patronage trough. Since the provincial government was the main source of party reward for Liberals, it followed that those with unorthodox views like annexation would be dealt with sternly and quickly. A cartoon in Grip magazine on 2 July 1892 poked fun at the disciplinary action by showing an applauding Colonel Denison - the arch imperialist and Conservative - in the balcony overlooking the signing of Meyer's dismissal. ${ }^{532}$ In reality however, prospects became deadly serious for those in the Liberal party who relied on "boodle" as part of their livelihood.

\footnotetext{
${ }^{530}$ Globe, 22 June $1891,1$.

${ }^{531}$ Noel, S.J.R. "Oliver Mowat, Patronage, and Party Building," in Ontario Since Confederation. ed. EdgarAndré Montigny and Lori Chambers. (Toronto: U of T Press, 2000), 97.

${ }^{532}$ Carman Cumming, Sketches from a Young Country: the Images of Grip Magazine, (Toronto: University of Toronto Press, 1997), 190.
} 
Farrer, not surprisingly, was the next to fall. It is unclear to what extent Farrer's "resignation" was forced. It was printed in The Globe of 27 July 1892, as a neat and laudatory announcement, thanking Farrer for his services. ${ }^{533}$ Farrer was a survivor, and went to great lengths to keep his ties with the Liberal party, unlike Meyers. Laurier received a letter from Farrer a month later on 16 August 1892 informing him that Farrer was happy to be of service to the Liberals in any way possible. ${ }^{534}$ The Grip cartoon of 31 August 1892 pictured the angelic Sir Oliver casting out of Canada the demonic personage of Edward Farrer ${ }^{535}$ Clearly, the Liberal papers had gotten the message too: annexation was not to be tolerated and in the Golden Age of patronage, upsetting the Party was never in one's best interest. ${ }^{536}$

The public dismissals of Meyers and, more importantly, Farrer had a tremendous impact on the discourse of conitnentalism as it appeared in the major Liberal organ, The Globe. Historians have been uniquely attuned to the power of newspapers. Paul Rutherford's now classic study, A Victorian Authority, states that the Canadian “...daily press was the prime mythmaker." ${ }^{937}$ Rutherford explains that these myths popularized by the press included the dogma of modernity, the gospel of order, the gospel of harmony and the illusion of sanity. ${ }^{538}$

\footnotetext{
${ }_{533}$ Cumming, Secret Craft, 215-216.

${ }^{534}$ Farrer to Laurier, 16 August 1892, Letter, Sir Wilfrid Laurier Papers, LAC, Ottawa, c-738.

${ }^{535}$ Cumming, Secret Craft, 220.

${ }^{536}$ For a discussion of patronage during the period see Simpson, Jeffrey. Spoils of Power: The Politics of Patronage. Toronto: JCS, 1988; Noel, S.J.R. Patrons, Clients and Brokers: Ontario Society and Politics, 1791-1896. Toronto: U of T Press, 1990; and; Gordon T. Stewart, The Origins of Canadian Politics, Vancouver: UBC Press, 1986.

${ }^{537}$ Paul Rutherford, A Victorian Authority: The Daily Press in Late Nineteenth Century Canada, (Toronto: University of Toronto Press, 1982), 156.

${ }^{538}$ Ibid., 156-189.
} 
The newspapers of the late nineteenth century were party newspapers both in orientation, ownership and often editorial discretion. As such, mass circulation newspapers must be understood as fully a part of the state system. Newspapers of the late nineteenth century like the Globe tended to reflect the views and wishes of the party elite in most cases. The Globe and other party organs, through the deployment of the above mentioned mythic constructions, were able to denounce continentalism and political union as a source of disorder and disruption for the political community. ${ }^{539}$

A clear example of this appeared in The Globe 7 July 1892 in a report by the correspondent "Uncle Thomas" on a political union meeting at Orangeville.

A fierce blow was struck at the autonomy of Orangeville and the remainder of the empire this evening and a daring struggle was made to snatch the nation from the hands of her patriotic and withal peaceful possessions...I wondered how a disturbing hand could ruthlessly stir it up from the bottom and mar the clear current of humanity with murky clouds of translucent disloyalty. ${ }^{540}$

"Uncle Thomas" went on to paint a picture of pastoral idealism full of "... prosperous establishments...children lolling in the grass...[and a] leisurly brooke." Contentment abounded with the knowledge that they shared the same sun "...that is reported never to set on the dominions of England." The paper was also quick to deploy the imperialist racial discourse, marvelling at why "...there were men striving to take this pleasant picture down from the automatic nail and hand it over to the foreigner." ${ }^{541}$

These men were the annexationist speakers. Though a small and dwindling movement, it was largely the fashion of advocates to travel from community to

${ }^{539}$ J.S. Mill, On Liberty, in Classics of Moral and Political Theory, (Ed. Michael L. Morgan), (Indiannapolis: Hackett, 1992), 1049.

s40 "Political Union", Globe, 7 July 1892, 2.

${ }^{541}$ Ibid. 
community, much as their commercial union fore-bearers, and hold meetings where the possibility of political union was discussed. Though Uncle Thomas was always sure to give praise for the eloquence of one speaker, Elgin Meyers, the tone of the article is unmistakably hostile to the cause. The real message is hammered home by the final passage. "As he [Meyers] was closing a small stone entered unannounced through a pane of glass and constituted itself the only active hostile demonstration." ${ }^{942}$ Though concluding that most at the meeting were in sympathy with continental union, it was clear that the rhetoric and imagery of the article aimed to teach readers to think of continental union not in terms of its advantages or disadvantages for governance, but rather in terms of its potentially disruptive consequences; political union and continentalism would lead to disorder and violence. Individuals who contributed to social disorder were not the same as those who sought governance by other means and to other ends. As such, they could not rightfully participate as members of the political community. Continental Union was outside the pall of normal governance and no longer a debatable option.

This characterization of continental union did not end with the correspondent Uncle Thomas. Rather, examples of the same discourse are prevalent throughout the pages of the Globe. On 30 November the Globe reported on an incident at the Young Liberal and Young Conservative Clubs in Toronto, where a leaflet advocating political union was distributed. When commenting on who may have been behind the distribution of this leaflet, the Globe had the following to say:

We have no idea, however, that any club had any responsibility for the distribution, or that any good end would be served by mobbing the distributors. It is the lesson of

${ }^{542}$ Ibid. 
history that violence breeds converts for the cause assailed, and that a free press are the safety valves of British institutions. ${ }^{543}$

This line or argument served two purposes: firstly, by emphasizing the socially disruptive nature of political union by playing upon fears of mobocracy to generate a sense of instability and insecurity; and secondly, by invoking British institutions as synonymous with order against the use of violence it establishes in the minds of the reader the sense that political union was outside the spectrum of legitimate political behaviour.

This journalistic trend at the Globe continued and increased in intensity throughout the following months. In December the Globe began regular front page segments titled "The State of the County" which all reported essentially the same story from each of the counties thought to be a hotbed of annexation. The pieces are remarkably similar in their structure and content. They emphasize the "extreme" opinions of some that no annexationism existed and the equally "extreme" opinions of others that annexationism was everywhere. Instead, they project the impression of the county in a state of unrest as a result of the unfair trade relations established by the Conservatives. Thus, in the new Liberal discourse it was continentalism and the National Policy which were both disruptive to the proper governance of society. An editorial appearing 15 December 1892 in The Globe was uncharacteristically blunt about the new party line on annexation. It was to be thought of as the dialectical offspring of the disorder brought about by the National Policy: "... something is wrong and therefore something must be done." ${ }^{44}$ Briefs like this and editorials outlining the social disruptive nature of

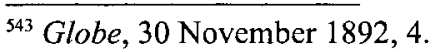

${ }^{544}$ Globe, 15 December 1893, 4. 
annexationism such as the 24 December's "Annexation Boom" created a link in the public imagination between annexation and the National Policy and a causational relationship between annexationist sentiments, the National Policy and social instability.

The final tactic employed by the Globe was to publish articles on the presence of Conservative annexationists. The purpose here was to show Conservative tolerance of annexationism. On 12 January 1893, a letter to the editor detailed the wide extent of support within the Conservative Party for Solomon White, the bovine smuggler from chapter two and a known annexationist. ${ }^{54}$ The implication was that the problem of continentalism was not one of party, but rather an affliction of the whole political community that had to be eliminated.

All in all, the strategy of The Globe was highly effective in changing the discourse that surrounded annexationism and continentalism. This provides an early example of what in contemporary parlance is referred to as "agenda setting," or the reordering of the publics sense of priorities by deliberate manipulation of the news. First, annexationism became the underlying cause of visible social disorder and as such should be avoided in the name of harmony and security. Annexationism, according to the Globe, was a movement of class dissatisfaction and dysfunction in the nation's National Policy culture, rather than actual disloyalty. This dysfunction was prevalent in both parties and as such should be discarded at the earliest convenience. By applying the same logic to the National Policy, action for the sake of action regardless of the outcome, the two could be characterized as similar in their logical outcome: social disruption. And, finally, the Globe message suggested that the Conservatives were opportunistic, ready to sell the $\overline{{ }^{545}}$ T.W. White, Globe, 12 January $1893,3$. 
country to Americans at the first possible moment if it meant electoral success and consequently had done nothing to deal with the annexationist problem. With this battery of allegations with which to bombard the reader, the Globe played an even more decisive role in undoing the annexationism it had once sparked under the guidance of Edward Farrer. This line would continue almost unchanged, save for an increasingly confident tone, right through until the Liberal electoral victory of 1896.

Through the mechanisms of the old politics - the partisan press and patronage the Liberals were able to deal effectively with annexationism and ensure its illegitimacy as a counter-conduct. By delegitimating the movement the party was able to exclude it from the spectrum of legitimate political behaviour for anyone taking the label Canadian or Liberal. What was needed was a way to show the Liberal's loyalty to the rest of the nation. The Liberal's new politics of loyalty needed to be performed for all to see.

Consolidating the New Politics of Loyalty, 1893-1896

The stage was set for the great drama of loyalty in the opening days of the 1893 parliamentary session. A resolution was passed by the Liberal caucus to hold a convention, which Laurier was all too eager to endorse. ${ }^{546}$ Districts were given the opportunity to send five representatives each along with the local candidate or sitting member to represent them at the convention. It was the very first such convention in Canadian history and, as such, is worth a closer examination to understand its relationship to the destruction of continentalism.

\footnotetext{
546 J.W. Lederle, "The Liberal Convention of 1893," in The Canadian Journal of Economics and Political Science, Feb. $19506(1), 44$.
} 
The historiography of the convention is scant. The 1950 article by J.W. Lederle on the convention hails it as an experiment in democratic decision-making. ${ }^{547}$ This is in spite of identifying the high level of behind the scenes management and surveillance that went on. ${ }^{548}$ A more reasonable view of the convention is offered by P.B. Waite in Canada, 1874-1896: Arduous Destiny and Christopher Pennington in his dissertation The Continentalist Movement in the Politics of Canada and the United States, 1887-1894. Waite and Pennington both detect a high degree of stage managing at the convention. ${ }^{549}$ Waite states that "the convention watered down the enthusiastic continentalism that had branded the party for the past five years...", but otherwise seemed to serve the purpose of consolidating Laurier's position. ${ }^{550}$

Yet, from earlier analysis in this chapter, it is fairly clear that prior to the convention a great deal had been done in the way of disciplining the party away from a continental vision. Rather, the convention was to be a crowning symbol of the successes of the campaign to move the party away from continentalism, and by extension the politics of "veiled treason". In the face of rumours that the Liberal Party might disintegrate in the wake of the 1891 loss, the convention offered an opportunity for a show of solidarity on the part of the seemingly fractured party.

The convention convened in the Rideau Rink in Ottawa on 20 and 21 of June 1893. The choice of Ottawa as the location of the convention was significant as it reinforced the significance of the convention as a national gathering and associated it with the national capital and all its resonance of loyalty to the ideal of Canada as an

\footnotetext{
${ }^{547}$ Ibid., 52.

548 Ibid., 50.

${ }^{549}$ Waite, Canada 1874-1896, 240 \& Pennington, 268.

${ }^{550}$ Waite, Canada 1874-1896, 240.
} 
independent nation. Choosing Toronto or Kingston would have meant reinforcing the province of Ontario's hold on the party, thereby making the party seem parochial and disconnected from the nation as a whole.

Aside from the choice of location, the proceedings of the convention were also significant. Despite the claim by James Sutherland, the Liberal MP from West Oxford that "No program has been made out, and no rules for governing this meeting...no cut and dried resolutions have been prepared to present to the meeting", there is evidence that the proceedings on the floor were heavily managed. ${ }^{551}$ The Laurier papers contain a draft resolution on the trade and tariff question, printed sometime around January of 1893 , almost identical to that passed at the convention, suggesting that the Liberal leadership had decided a full six months in advance the Party stance on the most important question of the convention. ${ }^{552}$ A letter written on 2 June 1893 noted that the party faithful were excited about the convention, a mood which the correspondent interpreted to mean they had given Laurier “...leave to be ruled with a rod of iron." ${ }^{553}$ The Royal Templars of Temperance had also decided to submit a set of motions to the convention for consideration. ${ }^{554}$ These motions were conspicuously absent from the discussion at the convention, further evidence that the convention was being carefully groomed. Discipline was also evident during the proceedings. Committee Chairs were evidently seconded in advance. MPs and other party officials made up almost three-quarters of the members of

${ }_{551}$ The Liberal Party of Canada National Convention, Official report of the Liberal Convention [microform] : held in response to the call of Hon. Wilfrid Laurier, leader of the Liberal Party of the Dominion of Canada : Ottawa, Tuesday, June 20th and Wednesday, June 21st, 1893., (Toronto : Budget Print. and Pub. Co., 1893), 15.

${ }_{552}$ Tariff Reform Motion, n.d., Sir Wilfrid Laurier Papers, LAC, Ottawa, c-738, 2377.

5532 June 1893, Letter, Sir Wilfrid Laurier Papers, LAC, Ottawa, c-738, 2501.

${ }^{554}$ Royal Templars of Temperance Policy Proposal, n.d., Sir Wilfrid Laurier Papers, LAC, Ottawa, c-738, 2528. 
the all-important policy committee and the entirety of all other committees. ${ }^{555}$ Almost every decision in the committees and on the floor of the convention was unanimous in a meeting that was supposed to be democratic rather than consensus building. ${ }^{556}$ Debate was also heavily monitored. Regular members of the Party who spoke, and there were few of these, were cut off for the sake of time when any of their utterances deviated from the program. One farmer, for instance, chose to criticize the lack of a policy to deal with the poor mail service in the rural areas was premptively cut off. ${ }^{557}$ Laurier had been clear earlier about the very organized and predetermined nature of the convention: "Sir, I respect all these opinions; but listen to me when I say that we should not indulge in speculative politics. This convention ought to be confined, to plain and practical questions." $\$ 58$

The choice and order of speakers was also revealing. Oliver Mowat was chosen as chair of the convention and given the honour of speaking first. Given that Laurier was the national leader, this would seem strange, but the choice of Mowat was related to the popular perception held by Liberals and Conservatives alike that his anti-continentalist views were beyond question. ${ }^{559}$ It also signalled that the Liberals were the party of provincial rights and that the voice of the provinces would be heard in a Liberal-run Ottawa. The choice of Mowat as chair and to give the first address signalled the tone of the convention.

\footnotetext{
${ }^{555}$ Lederle, 47-50

556 Ibid.

${ }^{557}$ The Liberal Party of Canada National Convention, 91.

558 Ibid., 30.

${ }^{559}$ Pennington, 268.
} 
Mowat began by congratulating all the Liberals there "...loyal as I know you all are..." for selecting Victoria Day as the date of the convention. The implication was obvious. Anything other than loyalty to the British connection would not be tolerated. Furthermore, the choice of Victoria Day had the added implication of associating the Liberal Party and the convention with the British crown and the mother country rather than the United States. Mowat went on:

Our country, in the largest sense, is the British Empire...Our grievances are brought on us by the mistakes of our fellow Canadians and the wrongdoings of some of them...My desire in what I say [regarding annexationist opinion is] to avoid exciting subjects on which we may not be united. But if on an occasion such as this I should say nothing about annexation or British connections, and there should be ascertained to be some annexationists in the convention to be against me on these subjects, and that for that reason I had said nothing. Such a notion would cause a sufficient stampede from the Reform ranks to make our success at the next general election out of the question. ${ }^{560}$

Aside from its obvious similarity to the content of earlier rhetoric of the Globe and the implication that any discovery of annexationists at the convention implied they did not belong. Annexationism for the Liberal party had become the enemy within. To be anything but loyal to Britain was to be no longer Canadian as even the Conservative loyalty cry became something to be respected, if the logic of Mowat's final sentence is followed.

Many of the subsequent speeches bore a striking resemblance to that delivered by Mowat. Laurier spoke second at the convention and added some important additions to Mowat's line of argument:

${ }^{560}$ Ibid., 6-7. 
Every child born upon the soil should remain a citizen of Canada for all his [sic] life... Yet on everyone of those farms [in Orangeville] they deplore the loss of a son or daughter who has gone to the United States to find what his own native country does not give him. This is the strongest possible arraignment of the policy of the present government that, with the undoubted advantages we have, these people of Orangeville...cannot keep their children at home. ${ }^{561}$

Laurier went on to say that the Liberal party condemned the tariff and its inspiration: the American system of Alexander Hamilton. ${ }^{562}$ The implication was that the National Policy was itself a continental policy, inspired by the United States. For Laurier, the Liberal party had to "...go for an example to the mother country and not the United States." 563 After all, reasoned Laurier, "the ideal system is the British system of free trade." ${ }^{564} \mathrm{He}$ then blamed the Conservatives for having "...driven out of the country [so many Canadians] to swell the numbers and the wealth of the United States." 565

Laurier successfully reengaged the theme of social disruption as it had been developed in the pages of the Globe for almost a year. ${ }^{566}$ What is most striking is the decision to use the rhetoric of loyalty rather than that of material well-being to frame the argument for reciprocity. Laurier's speech was evidence enough that the new politics would not be those of economic growth or of material improvement, but rather the politics of imperial connection, in the slipstream of which economic life in Canada might improve.

${ }^{561}$ Ibid., 27-28.

562 Ibid., 32.

${ }^{563}$ Ibid., 33

564 Ibid.

565 Ibid., 42.

${ }^{566}$ Work on the history of Canadian migration to the United States by Randy Widdis suggests that these migrations across borders were not socially disruptive, but rather tended to promote material and social stability within the family - See Randy William Widdis, With Sarcely a Ripple: Anglo-Canadian Migration into the United States and Western Canada, 1880-1920. Montreal: McGill-Queen's UP, 1998. 
Loyalty was not only reflected in the speeches and the timing of the convention, but was also present in the careful construction of the physical surrounding. Both the Liberal and the Conservative press were in attendance at the meeting and the organizers did their best to make both feel that they were attending a loyal gathering. The Tory owned Montreal Gazette called it “...the greatest political gathering ever held in Canada." 567 The hall had been decorated for the event and as the Globe pointed out:

All the flags and ensigns of all the nations of the earth are there, but in the combination of colours the red white and blue of the Union Jack stand out conspicuously. The centre feature of an artistically arranged background to the platform is an excellent portrait of Queen Victoria and on either side the coat of arms of Ontario, Quebec, Nova Scotia, and British Columbia. Directly opposite the platform is the motto 'Laurier our Leader', and entwined about it is the old flag. ${ }^{568}$

Laurier, just as Macdonald had two years earlier, wrapped himself in the "old flag" to reenlist the rhetoric of civic virtue for his cause. The preassembled slogans ringing the outside walls of the Rideau Rink not only invoked the language of loyalty, but conveniently fit with what would eventually be adopted as the policy of the Liberal party through the orchestrated democracy of the convention. The presence of symbols of national unity and the British connection were designed to inspire a sense of loyalty and to communicate the new-found anti-continentalist sentiments of the Liberal Party to a wider audience.

The convention had largely achieved its end of removing any doubt as to the Liberal party's loyalty. A letter to the Globe on 24 June 1893 explained that "if any doubt existed as to the policy of the Liberal Party [it is no longer the case]...the Liberal Party of

\footnotetext{
${ }^{567}$ Lederle, 46.

${ }^{568} \mathrm{Ibid} ., 47$.
} 
Canada fights beneath the banner of free trade...it and the Union Jack interweaving in the breeze. $" 569$ It stood as evidence that the Liberals were loyal and that as far as the Liberal Party was concerned, annexationists were not Liberals, nor were they Canadians.

Following the convention Laurier received a letter which declared the convention a success as "...the disloyalty-cry whilts [sic] at the moderate character of our policy." 570 The convention had shown that continentalism was no longer considered acceptable political behaviour for either a Liberal or a Canadian.

Unfortunately, there is no way systematically to measure the effect of the anticontinentalist campaign of the Globe, or the policy convention on Ontario society. There are small anecdotes from diffuse occurrences, such as those outlined in the opening of the chapter, that hint at the impact the Liberal efforts had upon the general populace. When Conservative J.J. Cosgrove along with three other Toronto members accidentally helped organize an annexationist meeting, they were dismissed from their positions in the civil service. ${ }^{571}$ A Young Conservative named James Curry was subjected to pressure and almost removed from the organization for being a member of the Continental Union Association. ${ }^{572}$ By 1 December 1893 the Globe was reporting that "...the feeling in Canada for annexation with the United States is so small as to be infinitesimal." ${ }^{\text {573 }}$ There were no more questions as to the validity of the annexationist opinion, only when it would finally be eradicated.

\footnotetext{
${ }^{569}$ Globe, 24 June 1893.

570 29 June 1893, Letter, Sir Wilfrid Laurier Papers, LAC, Ottawa, C-738, 2533.

571 Globe, 30 March 1893, 4.

${ }^{572}$ Globe, 7 February 1893, 4.

${ }^{573}$ Globe, 1 December 1893, 1.
} 
From the fall of 1893 until the following October, the department of justice decided to indulge this ascendant paranoia regarding annexation and continentalism in general by recruiting a spy to keep tabs on the cross border movement and its key Canadian members: Goldwin Smith and Erastus Wiman. The motivation seems to have been on surveilling the American movement in the hopes of finding evidence of Liberal wrongdoing as well as tracking the Canadian annexationist and commercial union movements. ${ }^{574}$ When nothing concrete was discovered the project was abandoned.

This repositioning of the Liberal Party's annexationist sentiments carried Laurier and his followers into the 1896 election. At a campaign stop in East York in 1896, Liberal candidate Mr. Stewart criticized the loyalty of the Conservative candidate, Mr. McLean. The Conservative accused the Liberals of having been recently "[h]urrahing for annexation". The Grit response to McLean's loyalist taunting was telling:

The Liberals who were in the hall, and there were many, jumped to their feet at this, and a perfect storm of dissent descended upon Mr. McLean, 'That is not true!' 'Take it back!' was called out from all sides. 'Who burned the parliament buildings?' came from one part of the hall, and "did Sir John Abbott sign the annexation manifesto?" was the cry from another. One big man with a flaming red necktie and a serviceable-looking club pounded on the seats [signalling the end of the meeting]...God Save the Queen came from one lusty throat and the cry was taken up by everybody in the hall..$^{575}$

Politics, it seemed, had become a straightforward contest of loyalties; a dance in which the music and the steps never changed, rather, the only judgment would be who had mastered the steps most effectively. Yet, just as politics had become more

\footnotetext{
${ }^{574}$ See T Burke Grant to D. Creighton, 24 November $1893-22$ October 1894, Letters, Records Relating to American Annexationists - Justice Department Fonds, LAC, Ottawa.

${ }^{575}$ Globe, 17 June $1896,8$.
} 
straightforward, Canadian society also became less inviting for those who held continentalist views, which were now well outside the language of the Canadian political community. In 1896, the Senate of the University of Toronto nominated Goldwin Smith for an honourary degree. ${ }^{576}$ The decision to nominate Smith by the Senate led to the resignation of Justice Falconbridge from the Senate and condemnation from several pens, including that of arch-imperialist, Geroge T. Dennison. ${ }^{577}$ The defensive position of the University clearly demonstrated the impact of the preceding five years: "In voting in favour of confering this degree on Mr. Smith, I never for a moment supposed that anyone would allege that I was approving of his religious or political views...". ${ }^{578}$ Smith received the degree, but not before it was turned into a scandal for him and the university. ${ }^{579}$

Continentalism was not summarily discredited by Macdonald's appeal in 1891 to some innate loyalist sentiment among Ontarians, but rather was progressively pushed from the realm of acceptable political alternative as a result of a multi-year project employing diverse tactics in order to de-legitimate continentalism. Macdonald issued the loyalty cry and his death certainly limited the official discursive space allotted to continentalism, reducing it to a narrow movement for political union and one whose "Canadianess" was increasingly suspect. It was the Liberals in the years between the 1891 and 1896 elections, who set the tone and pace for this creeping redefinition of the boundaries of Canadian political discourse. With Laurier's election victory in 1896 the linguistic boundaries of the political community had decisively and significantly changed.

${ }^{576}$ Globe, 25 June $1896,2$.

${ }^{577}$ Ibid.

${ }^{578}$ Ibid.

${ }^{579}$ Ibid. 
The Tariff Commission of 1896

Shortly after their victory in 1896 , the new Liberal government under the leadership of Wilfrid Laurier established the first tariff commission since the creation of the National Policy. The commission was, on the one hand, an attempt to be seen to fulfill their election promise to re-evaluate the tariff and, on the other, an attempt to place the tariff in the hands of experts, putting it beyond the scope of partisan politics. It was a commission that produced very little in the way of new policy of changes to the tariff. What it did accomplish though was the stifling of tariff politics in the Dominion. Of the five members all but one, Richard Cartwright, were opposed to continentalism. As the commission travelled across Canada for a year gathering information and submissions on the effects of the tariff, the opinions of manufacturers and businessmen spoke for the continuation of the National Policy system. Witness after witness when responding to the questioning of Fielding, Mowat or Paterson would justify the continuation of the tariff on the grounds of its necessity to keep jobs in Canada, or to keep Canadians manufacturing certain articles. Cartwright, though outnumbered, would occasionally challenge some of these assertions. In the case of yeast Cartwright pointed out that Canada never used to import yeast before the National Policy was introduced. The response from the Dominion Brewers Association was telling: "You go back too far." ${ }^{580}$ Indeed, Cartwright's critique seemed like an echo in favour of a continentalist policy that was no longer in step with the new economic and political imaginary of Canadian life. Whereas the 1880 s had been a decade of possibilities for those who saw Canadian identity as something extending

$\overline{580}$ Tariff Commission, 1896-1897, Evidence, RG-36-8, Vol. 1, Library and Archives Canada, Ottawa, ON, 10. 
beyond the political boundary of nation and the tariff, the 1890s saw the emergence of a new consensus in Canadian politics, as the trauma of the first three years of the decade robbed Canadians of the political language with which to articulate that continental vision. Certainly reciprocity was still there, but as a "British" policy not a continental one and so it would stay until its defeat in 1911. Continentalism as a political alternative rooted in a civic republican tradition had reached the end of its influence in Canadian society. 


\section{Conclusion: \\ August 31, 2007 - Wolfe Island}

I am back on the "other side of the line" now. Ithaca during "frosh week", The Chapter Bar, Finger Lake wine tasting, and of course, Goldwin Smith Hall are all memories now. The taste of lightly oaked Pinot Noir, the sounds of one-upmanship among first year law and MBA students, the hillside view of the Cornell campus and Goldwin Smith hall from the President's House are all inaccessible now. Gone in real terms, and left only in fragments, images, sensations that my mind tries to piece together; to make whole and coherent once more.

I cannot help but think of my visit to Goldwin Smith Hall. It was the secret reason I had decided to tag along with my friend on his visit to Ithaca at the last moment. I wanted to see what kind of monument would be left for such a man as Goldwin Smith. Such a man who often went against the grain, who championed the lost cause, in part, I think, because he enjoyed playing the underdog. As it turned out, it was home to the humanities. English, Art, History, Philosophy, and others all seemed to conduct classes or have offices within its fine walls. Above the main foyer, a Byzantine dome juts upwards

- the mark of culture - as granite walls all around point to the building's origin among the rocks and landscape of a continent an ocean away from its byzantine inspiration. It is at once a place of contradictions. As one enters from the front double doors, immediately one is confronted with an excerpt, moulded in bronze, from Goldwin Smith's final will and testament:

All the rest and residue of my estate I give, devise and 
bequeathe, to Cornell University...my desire is to show my attachment to the university in the foundation of which I have had the honor of taking part and to pay my respects to the memory of Ezra Cornell and to show my attachment as an Englishman to the union of the two branches of our race on this continent with each other and their common mother. ${ }^{581}$

Over to the right, above the entrance to what is now a cafeteria, is a further plea by the Bystander for the unity of the people of the Anglo-Saxon race and in particular the two great nations that are estranged from each other on this continent to this day. At the bottom it reads: "Above all Nations is Humanity." word.

As I look across from the deck of the ferry at the lights of Kingston on a clear summer night like this one, I am reminded why this city must have once thought itself destined for greatness. The home of the likes of John A. Macdonald and Richard Cartwright, the training ground for Oliver Mowat, it must have seemed in the nineteenth century that Kingston was a city on its way up. A sentiment which certainly extended back beyond the city limits into the other cities and villages of the then youthful Dominion.

Yet, standing as I am, about to shove off from Wolfe Island for the mainland, I know in the back of my mind that only a few kilometres behind me, the shores of the Republic are easily accessible by ferry in the summer from an island which is barely

\footnotetext{
${ }^{581}$ Goldwin Smith, Excerpt of Last Will and Testament, [Plaque], Itaca, NY: Goldwin Smith Hall, Cornell University.

${ }^{582}$ Dedication. [Plaque], Itaca, NY: Goldwin Smith Hall, Cornell University.
} 
scarred by the marks of state intrusion. As a local said to me, "There is no police detachment here. The island is a little wild."

The summer students-cum-customs officials at the Wolfe Island border crossing seemed to know that they were in a dubious position in such a bastion of anarchy. They seemed a little timid or ambivalent, a little less eager to question the smiling summer tourists drifting back and forth from one side of the line to the other. Perhaps it is because, like their nineteenth century counterparts, their customs house closes at night and, in the winter months, it ceases to exist altogether. A wild place indeed, where borders still reside largely on maps and in our imaginations.

The border crossing at Wolfe Island is not the only thing which harkens back to an earlier time. Like our continentalist counterparts of the nineteenth century, we still lament and worry about the young talent being lost to the United States on account of the socalled "brain drain". Yet, unlike them, we see this decision to cross over the line as some kind of moral failing by the individual, some base impulse to simply accumulate more material possessions. We are still concerned with the effect that great wealth has on great virtue, yet we are concerned about such things on individual terms, not communal as the continentalists were. To cross over the line is to remove oneself from the community, but not an event which inspires the community to ask itself what it is doing wrong. We ignore that what is really at issue is the government's competence to provide for the population as organisms, something that continentalists were particularly concerned about. We ignore that the decision to leave Canada is not some moral failing, but a 
political act that challenges the very premise of Canada's existence. We ignore this or close our eyes to it, because to do so allows us to sleep better at night. Contrary to so much of the rhetoric, deep down in places it is sometimes hard to speak of, we know that Canada is hardly anything unique, hardly so separate as we pretend. Dreams, though, are every bit as convincing as the cold hard material reality.

Though a study of continentalism in the late nineteenth century covers only a small period in the long history of Canadian-American interactions, it is an definitive one. It serves to remind us about the interconnectedness these two countries have always shared and continue to share in all matters of the mundane. The movement of people and goods, the drift of ideas and institutions continue irrespective of the will of political masters. And it is this small truth, that carries more weight than any diplomatic history of what the Canadian and American governments think of each other at any given time.

There are also great ruptures of understanding between the late nineteenth century and the early twenty-first. In thinking about how it was that these continentalists phrased their claims, it is important to note that ideas of left, right, and centre are meaningless in this context. Canadians did not speak politically as right or left, but rather as liberals, republicans, or tories. They drew upon political traditions in an effort to articulate their particular positions. Politics were not linear or spectral, but schematic, layered and overlapping. It looked more like a constantly shifting set of overlapping spheres. Whether Marxist, syndicalist, civic republican or liberal, all of these groups spoke of freedom, of a state which had a significant role to play in this process, and of similar strategies, tactics and institutions aimed at ensuring their particular definition of freedom. 
What they disagreed on was how those tactics and strategies could be most effectively organized and deployed and in what context different tactics were acceptable. A liberal order, or any hegemonic order, is purely a figment of structuralist imaginations. Canada is no more and no less than a stage upon which the performance of history can be acted out. There is nothing significantly "Canadian" about it. From the influence of the American system upon the National Policy, to the impact of Jeffersonian republicanism on the continentalist movement in Canada, to labour movements which maintained strong cross-border ties with American counterparts there is no "Canada as process", there is no "uniquely Canadian" answer. Rather, Canada has always been and remains a word with differing and often divergent meanings. Its significance lies only in that it remains the terms of debate. It is the symbol that returns eternally in each moment, for each generation: the first time as romance, the second as tragedy. And here, I hope, Canada and the other constructs this thesis has explored have been in part at least, stripped down and laid naked. That we may move beyond the limitations of grandiose constructions, that we may look not for what Canada or liberalism or republicanism is, but rather, what it has meant and how it has inspired a variety of people at a variety of times. That we may think of population, nation, and civil-society not as things, but as dreams of the administrative imagination and avenues which those subject to its gaze and manipulations have sought to speak back in a language that those in the state understand. And finally, having climbed from the mouth of this cave, that we not return to its recesses to fight over the meaning of shadows, but that we stand here, somewhere beyond, and use the great light from above to see the contents of that shadowy, dimly-lit cave differently. 


\section{Bibliography}

\section{Primary Sources}

\section{Manuscript Collections}

Annual Report of Farmers' Institutes. RG 16-85. Archives of Ontario. Toronto, ON.

The Cartwright Family Papers [microfilm]. MS-1992. Archives of Ontario, Toronto, ON.

Department of Agriculture Fonds. RG-17. Library and Archives Canada, Ottawa, ON.

Department of Customs and Excise Sous-Fonds, RG-19 E-4-5; RG-16 A-2 \& A-3, Library and Archives Canada, Ottawa, ON.

Justice Department Fonds - Records Relating to American Annexationists. RG-13. Library and Archives Canada, Ottawa, ON.

Goldwin Smith Fonds, Library and Archives Canada, Ottawa, ON

John A. Macdonald Fonds, MG-26A, Library and Archives Canada, Ottawa, ON.

MacKenzie Bowell Fonds. MG-26-E. Library and Archives Canada, Ottawa, ON

Sir Wilfrid Laurier Papers. [Microfilm] C-738 - C-740, Library and Archives Canada, Ottawa, ON

Tariff Commission, 1896-1897. RG-36-8. Library and Archives Canada. Ottawa, ON.

The Walter Dymond Gregory Papers. Queen's University Archives, Kingston, ON.

\section{Newspapers}

The Advertiser. (London, ON)

The Empire. (Toronto).

The Toronto Globe.

The Canadian-American (Chicago).

The Bystander (Toronto).

The Canadian Livestock and Farm Journal (Hamilton, ON). 
Farmer's Advocate and Home Journal (London, ON)

Sentinel Review (Woodstock, ON)

The Stratford Beacon

Government Documents

Debates of the House of Commons. Ottawa: Queen's Printer.

Published Primary Documents

Adam, G. Mercer (ed.), Handbook for Commercial Union: a collection of papers read before the Commercial Union Club, Toronto : with speeches, letters and other documents in favour of unrestricted reciprocity with the United States. Toronto: Hunter Rose, 1888.

Annexation Association of Montreal. The annexation manifesto of 1849 [microform] reprinted from the original pamphlet, with the names of the signers. Montreal? : s.n., 1881.

Blake, Edward. Letter of the Hon. Edward Blake to the West Durham Reform Convention [microform] : to which is appended correspondence as to the Inverary meeting. Toronto:Budget Print. and Pub. Co., 1891.

Cartwright, Sir Richard. Canada go bragh [microform] : being an inaugural address to the Young Liberal Club, of Seaforth, Ont., on the 27th October, 1886. Toronto: Hunter Rose, 1886.

Cartwright, Sir Richard. Reminiscences. Toronto: William Briggs, 1912.

Cartwright, Sir Richard. Speech of Sir Richard Cartwright at Ingersoll, Nov. 14th, 1889. S.1.: s.n., 1889

Charlton, John. Speeches and addresses: political, literary and religious. Toronto: Morang, 1905.

Constitution and By-Laws of the Canadian Club of New York, (1885).

Fairchild, G.M. Canadian Leaves: History, Art, Science, Literature, Commerce. A series of papers read before the Canadian Club of New York. New York: Napoleon Thompson \& Co., 1887. 
The Liberal Party of Canada National Convention, Official report of the Liberal Convention [microform] : held in response to the call of Hon. Wilfrid Laurier, leader of the Liberal Party of the Dominion of Canada : Ottawa, Tuesday, June 20th and Wednesday, June 21st, 1893. Toronto : Budget Print. and Pub. Co., 1893.

Locke, John. The Fundamental Constitution of Carolina, n.d.

Macdonald, John A. Address to the Canadian People, February 7, 1891 [microform].

Machar, Agnes Maule [Fidelis]. "Our Life Blood Ebbs Away: A Plea for Continental Union” S.I.: S.N., 1890-1892.

Norman, Sir Henry. Commercial union as photographed by an intelligent English visitor to Canada [microform] : imperial interviews, number ten, in the Pall Mall gazette. New York: E. Wiman, 1888.

The Permanent Central Farmers' Institute of Ontario, Report of the Proceedings of the First Annual Meeting of the Permanent Central Farmers' Institute of Ontario. Hamilton: Griffin \& Kinder, 1888.

The Permanent Central Farmers' Institute of Ontario, Report of the Proceedings of the Second Annual Meeting of the Permanent Central Farmers' Institute of Ontario. Hamilton: Griffin \& Kinder, 1889.

Smith, Goldwin. The Saint George s Society and Goldwin Smith [microfilm]. S.1: s.n., 1896?

Smith, Goldwin. Canada and the Canadian Question. London: McMillan, 1891.

Smith, Goldwin. The greatness of England [microform]. S.1: s.n., 1879

Smith, Goldwin. Loyalty, Aristocracy and Jingoism: three lectures delivered before the Young Men's Liberal Club Toronto. Toronto: Hunter Rose, 1891.

Smith, Goldwin. The Political Destiny of Canada [microform]. Toronto: Willing and Williamson; London: Chapman \& Hall 1878.

Smith, Goldwin. Political relations of Canada to Great Britain and the United States: an address delivered to the Nineteenth Century Club, New York, on the 31st January, 1890. Toronto: Hunter Rose, 1890. 
Smith, Goldwin. Speech of Mr. Goldwin Smith, at the banquet of the Chamber of Commerce of the State of New-York, November 20, 1888. New York : Press of the Chamber of Commerce, 1888.

Smith, Goldwin. Women's Place in the State [microform]. S.1: s.n., 1890.

Spencer, Herbert. Essays, Scientific, Political and Speculative. New York: Appleton, 1916.

The Constitution of the United States of America in Madison, James; Hamilton, Alexander \& Jay, John. The Federalist Papers. London: Penguin, 1987.

Wiman, Erastus. Canada and Great Britain [microform] : report of Erastus Wiman on the Congress of the Chambers of Commerce of the British Empire, held in London, June, 1892. S.1.: s.n., 1892.

Wiman, Erastus. The Canadian Club, its purpose and policy [microform] : as set forth in the speech of Erastus Wiman, president, Dominion Day dinner, July 1, 1885. New York: s.n., 1885.

Wiman, Erastus. Chances of success: episodes and Observations in the Life of a Busy Man. Toronto: W. Briggs, 1893.

Wiman, Erastus. The Capture of Canada. New York: s.n., 1890.

Wiman, Erastus. Closest trade relations between the United States and Canada [microform]. Toronto: National Pub. Co., 1892.

Wiman, Erastus. Commercial union between the United States and Canada [microform]: some letters, papers and speeches. New York: E. Wiman, 1887

Wiman, Erastus. Union between the United States and Canada [microform] : political or commercial : which is desireable and which is presently possible? New York: s.n., 1891.

Wiman, Erastus. The union of telegraph interests in Canada [microform]: a letter to the shareholders of the Montreal Telegraph Company. New York?: s.n., 1881.

Images\Monuments

Dedication. [Plaque], Itaca, NY: Goldwin Smith Hall, Cornell University.

Keep out the wolves. [election poster], (The Industrial League, 1891), MG-26 A Vol. 609, Library and Archives Canada, Ottawa, ON. 
Goldwin Smith - Excerpt of Last Will and Testament, [Plaque], Itaca, NY: Goldwin Smith Hall, Cornell University

The Old Flag, The Old Policy, The Old Leader, [Election Poster], The Industrial League, 1891, MG-26A Vol. 608. Library and Archives Canada, Ottawa, ON.

The Way He Would Like It - Canada for Sale, [Election Poster], n.d. MG-26A Vol. 600, Library and Archives Canada, Ottawa, $O N$.

We Can't Undo the Lock, Sir John is On Guard, [Election Poster], (The Industrial League, 1891) MG-26A Vol. 612, Library and Archives Canada, Ottawa, ON.

\section{Secondary Sources}

\section{$\underline{\text { Monographs }}$}

Anderson, Benedict. Imagined Communities. London: Verso, 2006.

Azjenstat, Janet. The Canadian Founding: John Locke and Parliament. Montreal: McGill Queen's University Press, 2007.

Beck, J. Murray. Pendulum of Power; Canada's Federal Election. Scarborough, ON: Prentice Hall, 1968.

Berger, Carl. The Sense of Power: Studies in the Ideas of Canadian Imperialism, 1867 1914. Toronto: University of Toronto Press, 1970.

Biederman, Gail. Manliness and Civilization: A Cultural History of Gender and Race in the United States, 1880-1917. Chicago: University of Chicago Press, 1996.

Bliss, Michael. A Living Profit: Studies in the Social History of Canadian Business, 1883 1911. Toronto: McCLelland and Stewart, 1974.

Brown, R.C. Canada's National Policy, 1883-1900: A study in Canadian-American Relations. Princeton, NJ: Princeton University Press, 1964.

Creighton, D.G. Canada's First Century, 1867-1967. Toronto: McMillan, 1970.

Creighton, D.G. John A. Macdonald: the Old Chieftain. Toronto: Mcmillan, 1955.

Cumming, Carman. Secret Craft: The Journalism of Edward Farrer. Toronto: Universty of Toronto Press, 1992.

Cumming, Carman. Sketches from a Young Country: the Images of Grip Magazine. Toronto: University of Toronto Press, 1997. 
Curtis, Bruce. The Politics of Population: State Formation, Statistics and the Census of Canada, 1840-1875. Toronto: University of Toronto Press, 2002.

Dales, J.H. The Protective Tariff in Canada's Development. Toronto: University of Toronto Press, 1966.

Dean, Mitchell. Governmentality: Power and Rule in Modern Society. London: Sage, 1999.

Edkins, Jenny. Trauma and the memory of politics. Cambridge: Cambridge UP, 2003.

Frye, Northrop. "Conclusion to a Literary History of Canada." The Bush Garden: Essays on the Canadian Imagination. Toronto: Anansi, 1975.

Glueck, Alvin C. Minnesota and the Manifest Destiny of the North-West: A study in Canadian American Relations. Toronto: University of Toronto Press, 1965.

Graham, W.R. Richard Cartwright and the Liberal party, 1863-1896. Toronto: University of Toronto Press, 1950.

Granatstein, Jack. Yankee Go Home: Canadians and Anti-Americanism. Toronto: Harper Collins, 1996.

Honohan, Iseult. Civic Republicanism. New York: Routledge, 2002.

Hopkins, J. Castell. Life and Work of Sir John Thompson. Brantford, ON: Bradley Garretson \& Co., 1895.

Jalkand, Pat. Death in the Victorian Family. London: Oxford University Press, 1996.

Kohn, Edward P. This Kindred People: Canadian-American Relations \& the Anglos Saxon Idea, 1895-1903, Montreal: McGill-Queen's University Press, 2004.

McKay, Ian. Rebels, Reds, Radicals: rethinking Canada's left history. Toronto: Between the Lines, 2005.

McNairn, Jeffrey. The Capacity to Judge: Public Opinion and Deliberative Democracy in Upper Canada, 1791-1854. Toronto: University of Toronto Press, 2000.

Moss, Mark. Manliness and Militarism: Educating young boys in Ontario for war. Don Mills, ON: Oxford UP, 2001.

Noel, S.J.R. Patrons, Clients, Brokers: Ontario Society and Politics, 1791-1896. Toronto: University of Toronto Press, 1990. 
Nordin, D. Sven. Rich Harvest: A History of the Grange, 1867-1900. Jackson: University of Mississippi Press, 1974.

Phillips, Paul T. The Controversialist: An Intellectual Life of Goldwin Smith. Westport, Conn.: Praeger, 2002.

Rose, Nikolas. Powers of Freedom: Reframing Political Thought. Cambridge, UK: Cambridge University Press, 1999.

Rutherford, Paul. A Victorian Authority: The Daily Press in Late Nineteenth Century Canada. Toronto: University of Toronto Press, 1982.

Simpson, Jeffrey. Spoils of Power: The Politics of Patronage. Toronto: JCS, 1988.

Smith, Bruce James. Politics \& Rememberance: Republican Themes in Machiavelli, Burke and Tocqueville. Princeton, NJ: Princeton University Press, 1985.

Smith, David E. The Republican Option in Canada: Past and Present. Toronto: University of Toronto Press, 1999.

Stewart, Gordon T. The American Response to Canada since 1776. East Lansing, MI: University of Michigan Press, 1992.

Stewart, Gordon T. The Origins of Canadian Politics, Vancouver: UBC Press, 1986.

Taylor, Charles. Sources of the Self: The Making of the Modern Identity. Cambridge, MA: Harvard University Press, 1989.

Verdery, Katherine. The Political Lives of Dead Bodies: reburial and postsocialist change. New York: Columbia University Press, 1999.

Waite, P.B. Canada 1874-1896: Arduous Destiny. Toronto: McClelland and Stewart, 1971.

Waite, P.B. Macdonald: His Life and World. Toronto: McGraw-Hill-Ryerson, 1974.

Waite, P.B. The Man From Halifax; Sir John Thompson, prime minister. Toronto:

University of Toronto Press, 1985.

Wallace, Elisabeth. Goldwin Smith: Victorian Liberal. Toronto: University of Toronto Press, 1957.

Warner, D.F. The Idea of Continental Union: Agitation for the Annexation of Canada to the United States, 1849-1893. University of Kentucky Press, 1960. 
Widdis, R.W. With Scarcely a Ripple: Anglo Canadian Migration to the United States and Western Canada, 1880-1920. Montreal: McGill-Queen's University Press, 1998.

Wood, Louis Aubrey. A History of the Farmers' Movements in Canada. S.N.: S.I., 1924.

Woods, Thomas A. Knights of the Plow: Oliver H. Kelley and the Origins of the Grange in Republican Ideology. Ames, IW: University of Iowa Press, 1991.

Underhill, F.H. The Image of Confederation. Toronto: Hunter Rose, 1964.

\section{Edited Works Multiple Authors}

Azjenstat, Janet \& Smith, Peter J. (ed.) Canada's Origin: Liberal, Tory, or Republican? Ottawa: Carleton University Press, 1995.

Berger, Carl (ed.) Imperialism and Nationalism, 1884-1914: A Conflict in Canadian Thought. Toronto: Copp Clark Publishing, 1969.

Bukowczyk, John J. et al. Permeable Border: The Great Lakes Basin as Transnational Region, 1650-1990. Pittsburgh: University of Pittsburgh Press, 2005.

Carrigan, D. Owen. Canadian Party Platforms 1867-1968. Toronto: Copp Clark, 1968.

McCalla, Douglass (ed.) The Development of Canadian Capitalism. Toronto: Copp Clark Publishing, 1990.

Montigny, Edgar-André \& Chambers, Lori. Ontario Since Confederation. Toronto: U of T Press, 2000.

Morgan, Michael L. (ed.) Classics of Moral and Political Theory. Indiannapolis: Hackett, 1992.

Russell, Peter (ed.), Nationalism in Canada. McGraw-Hill: Toronto, 1966.

Wise, S.F. \& Brown, R.C. Canada Views the United States. Seattle: University of Washington Press, 1967.

Underhill, F.H. In Search of Canadian Liberalism. Toronto: McMillan, 1960.

\section{Theses $\backslash$ Dissertations}


Hodson, I.A. Commercial Union, Unrestricted Reciprocity and the Background to the Election of 1891. London, ON: University of Western Ontario, M.A. Thesis, 1952.

Forster, J.J.B. Tariffs and Politics: The Genesis of the National Policy, 1842-1879. Toronto, ON: University of Toronto, PhD Dissertation, 1982.

James Macdonald, A Genealogy of the Undefended Border: Denaturalizing current conceptions of the Canada-U.S. border through the use of Foucault's concepts of Genealogy and Governmentality. Ottawa: Carleton University, M.A. Thesis, 2003.

Pennignton, Christopher. The Continentalist Movement in the Politics of Canada and the United States, 1887-1894. Toronto: University of Toronto, PhD Dissertation, 2007.

Wood, Patricia. "Under Which Flag, Canadian?" Anti-Americanism and the Election of 1891. Kingston, ON: Queen's University, M.A. Thesis, 1991.

$\underline{\text { Journal Articles }}$

Conrad, Margaret. "Edward Farrer" The Beaver. 2007 Vol. 87(4): 37.

Cumming, Carman. "The Toronto Daily Mail, Edward Farrer, and the Question of Canadian-American Union," Journal of Canadian Studies 1980 Vol. 24(1): 121 139.

Craven, Paul \& Traves, Tom. "The Class Politics of the National Policy, 1872-1933" Journal of Canadian Studies. 1979 14(3): 14-38.

Dales, J.H. "National Policy Myths, Past and Present." Journal of Canadian Studies, 1979 Vol. 14(3): 92-94.

Forster, B; Davidson, M; \& Brown, R.C. "The Franchise, Personators and Deadmen: An inquiry into the voters list and the election of 1891." Canadian Historical Review, $198667(1): 17-41$

Graham, W.R. "Liberal Nationalism in the 1870s", in Canadian Historical Association (Report), 1946.

Grant, Ian. "Erastus Wiman: A Continentalist Replies to Canadian Imperialism." Canadian Historical Review 1972 53(1): 1-20. 
Kohn, Edward. "The Member from Michigan': The unofficial diplomacy and political isolation of John Charlton, 1892-1903." The Canadian Historical Review. 2001 82(2): 283-306.

Lederle, J.W. "The Liberal Convention of 1893," in The Canadian Journal of Economics and Political Science, 1950 6(1): 44-54.

Loo, Tina. "Making a Modern Wilderness: Conserving Wildlife in Twentieth Century Canada," in Canadian Historical Review. 2001 82(1): 91-121

MacKirdy, K.A. "The Loyalty Issue in the 1891 Federal Election Campaign and An Ironic Footnote." Ontario History. 1963 55(3): 143-154

McKay, Ian. "The liberal order framework: A prospectus for a reconnaissance of Canadian history" The Canadian Historical Review. 2000 Vol. 81(4): 617-645

Miller, J.R. "The 1891 Election in Western Canada", Prairie Forum 1985 10(1) 147-167.

Miller, J.R. "This Saving Remanent: Macdonald and the Catholic Vote in the 1891 Election", Study Sessions 1974 Vol. 44: 33-52

Moss, Jeffrey W. \& Lass, Cynthia B. “A History of Farmers' Institutes”, in Agricultural History, 1988 Vol. 62(2): 150-163.

Pennanen, Gary. "Goldwin Smith, Wharton Barker and Erastus Wiman: Architects of Commercial Union.”Journal of Canadian Studies 1979 14(3): 50-62.

Wood, Patricia. "Defining "Canadian": Anti-Americanism and Identity in Sir John A. Mcdonald's Nationalism” Journal of Canadian Studies, 2001 36(2): 49-69.

\section{Lectures}

Foucault, Michel. Security, Territory, Population: Lectures at the College de France, 1977-1978. Michel Snellart (ed.). London: Palgrave, 2007.

Foucault, Michel. Society Must be Defended: Lectures at the College de France 1975 1976. Mauro Bertani \& Alessandro Fontana (ed.) New York: Picador, 2003.

\section{Web Resources}

The Dictionary of Canadian Biography Online. http://www.biographi.ca. 